Huchon, P., Taylor, B., and Klaus, A. (Eds.)

Proceedings of the Ocean Drilling Program, Scientific Results Volume 180

\section{Petrography and Provenance OF VOLCANICLASTIC SANDS AND SANDSTONES RECOVERED FROM THE WOODLARK RIFT BASIN AND TROBRIAND FOREARC BASIN, LEG 180'}

Timothy R. Sharp ${ }^{2}$ and Alastair H.F. Robertson ${ }^{3}$

\begin{abstract}
Modal analysis of middle Miocene to Pleistocene volcaniclastic sands and sandstones recovered from Sites 1108, 1109, 1118, 1112, 1115, 1116, and 1114 within the Woodlark Basin during Leg 180 of the Ocean Drilling Program indicates a complex source history for sand-sized detritus deposited within the basin. Volcaniclastic detritus (i.e., feldspar, ferromagnesian minerals, and volcanic rock fragments) varies substantially throughout the Woodlark Basin. Miocene sandstones of the inferred Trobriand forearc succession contain mafic and subordinate silicic volcanic grains, probably derived from the contemporary Trobriand arc. During the late Miocene, the Trobriand outerarc/forearc (including Paleogene ophiolitic rocks) was subaerially exposed and eroded, yielding sandstones of dominantly mafic composition.

Rift-related extension during the late Miocene-late Pliocene led to a transition from terrestrial to neritic and finally bathyal deposition. The sandstones deposited during this period are composed dominantly of silicic volcanic detritus, probably derived from the Amphlett Islands and surrounding areas where volcanic rocks of Pliocene-Pleistocene age occur. During this time terrigenous and metamorphic detritus derived from the Papua New Guinea mainland reached the single turbiditic Woodlark rift basin (or several subbasins) as fine-grained sediments. At Sites 1108, 1109, 1118, 1116, and 1114, serpentinite and metamorphic

${ }^{1}$ Sharp, T.R., and Robertson, A.H.F., 2002. Petrography and provenance of volcaniclastic sands and sandstones recovered from the Woodlark rift basin and Trobriand forearc basin, Leg 180. In Huchon, P., Taylor, B., and Klaus, A. (Eds.), Proc. ODP, Sci. Results, 180, 1-58 [Online]. Available from World Wide Web: <http://www-odp. tamu.edu/publications/180_SR/ VOLUME/CHAPTERS/176.PDF>. [Cited YYYY-MM-DD]

${ }^{2}$ Department of Environmental Science, University of Technology, Sydney, PO Box 123, Broadway, Sydney 2007 NSW, Australia. tim.sharp@uts.edu.au

${ }^{3}$ Department of Geology and Geophysics, West Mains Road, University of Edinburgh, Edinburgh EH9 3JW, United Kingdom.

Initial receipt: 2 January 2001 Acceptance: 27 September 2001 Web publication: 6 March 2002 Ms 180SR-176
\end{abstract}


grains (schist and gneiss) appear as detritus in sandstones younger than $\sim 3 \mathrm{Ma}$. This is thought to reflect a major pulse of rifting that resulted in the deepening of the Woodlark rift basin and the prevention of terrigenous and metamorphic detritus from reaching the northern rift margin (Site 1115). The Paleogene Papuan ophiolite belt and the Owen Stanley metamorphics were unroofed as the southern margin of the rift was exhumed (e.g., Moresby Seamount) and, in places, subaerially exposed (e.g., D'Entrecasteaux Islands and onshore Cape Vogel Basin), resulting in new and more proximal sources of metamorphic, igneous, and ophiolitic detritus. Continued emergence of the Moresby Seamount during the late Pliocene-early Pleistocene bounded by a major inclined fault scarp yielded talus deposits of similar composition to the above sandstones. Upper Pliocene-Pleistocene sandstones were deposited at bathyal depths by turbidity currents and as subordinate air-fall ash. Silicic glassy (high-K calc-alkaline) volcanic fragments, probably derived from volcanic centers located in Dawson and Moresby Straits, dominated these sandstones.

\section{INTRODUCTION}

During Leg 180 (June-August 1998), a nearly north-south transect of six sites $(1116,1114,1108,1118,1109$, and 1115) was drilled with good recovery in the sedimentary sequence of the Woodlark Basin, from the rifted footwall, as exposed on Moresby Seamount, across the western rift basin, and on to the downflexed northern margin of the basin (Figs. F1, F2, F3). The objective of this paper is to utilize the modal analyses of the sandstones from the Woodlark Basin to infer sediment provenance. The results complement information on sediment composition and provenance obtained by shipboard observations (Taylor, Huchon, Klaus, et al., 1999; Robertson et al., 2001), a chemical and mineralogical study of mainly fine-grained argillaceous sediments from the Woodlark Basin (Robertson and Sharp, this volume), petrographic investigations of volcaniclastic sediments from the Woodlark Basin (Cortesogno et al., this volume), and a study of tephra layers and volcaniclastic deposits of the Woodark Basin (Lackschewitz et al., 2001).

\section{REGIONAL GEOLOGICAL SETTING}

The western Woodlark Basin is one of the best areas to study the processes of rifting as a precursor to seafloor spreading and is one of the few areas of the world where a very strong case can be made for ongoing rifting related to large-scale simple shear on a relatively low-angle $\left(\right.$ dip $=\sim 30^{\circ}$ ) extensional detachment fault (Taylor et al., 1995). Extension was achieved by westward propagation of a spreading center into the previously rifted continental crust of Papua New Guinea (Benes et al., 1994; Taylor et al., 1999). Extension commenced at $~ 6-8 \mathrm{Ma}$ in the western Woodlark Basin with rifting of the subduction-related Miocene Trobriand Arc adjacent to Papua New Guinea (Weissel et al., 1982; Taylor et al., 1999). Here, we include in the Woodlark Basin the entire sedimentary system associated with the western Woodlark Basin, including the uplifted footwall to the south, forming the Moresby Seamount, the deep rift basin, and the downflexed margin farther north (Fig. F3).

Interpretation of sediment provenance within the Woodlark Basin must take into account its complicated regional tectonic setting (Davies
F1. Regional tectonic setting of the Woodlark Basin, p. 25.

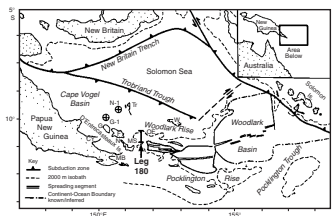

F2. Locations of Leg 180 sites, p. 26.



F3. Interpretations of northsouth seismic profiles, p. 27.

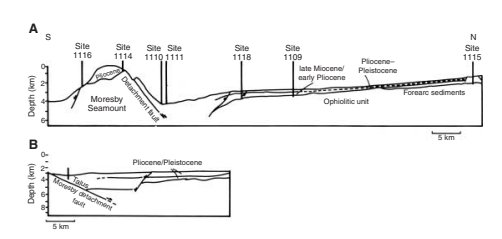


et al., 1987; Honza et al., 1987; Lock et al., 1987). During Neogene time, calc-alkaline volcanoes were active within an arc that was mainly located south of the present Woodlark Basin in Papua New Guinea (Smith, 1982; Smith and Milsom, 1984). However, similar calc-alkaline volcanoes were also located farther north within the present forearc region (e.g., Woodlark Island) (Ashley and Flood, 1981). Papua New Guinea, an obvious potential source of terrigenous sediment in the Woodlark Basin, is geologically complex and includes Neogene arc volcanics, a Paleogene ophiolite, and underlying metamorphic rocks (Davies and Jaques, 1984).

\section{GEOLOGICAL HISTORY}

The oldest sediments recovered, of middle to late Miocene age, at the most northerly site (Site 1115) are mainly deepwater volcaniclastic turbidites related to the Miocene Trobriand Arc. This arc resulted from southward subduction of oceanic crust of the Solomon Sea, located to the north (Honza et al., 1987; Davies et al., 1987). Seismic data suggest that a forearc sedimentary wedge is present beneath part of the Woodlark Basin (Fig. F3). Drilling at Sites 1109 and 1118 terminated in diabase and basalt, either as massive rock (Site 1109) or as conglomerate (Site 1118). These lithologies probably constitute part of a Paleogene ophiolite (Taylor, Huchon, Klaus, et al., 1999; Robertson et al., 2001).

During the late Miocene, the forearc underwent regional emergence, as documented during Leg 180 and by industry wells to the northwest (Harris et al., 1985). At Site 1109, fluvial channelized? conglomerates, deposited in a nonmarine paralic setting, were overlain by lagoonal and then open-marine carbonates. Similar conglomerates are abruptly overlain by open-marine carbonates, with abundant coralline algae at Site 1118 farther south. In the north at Site 1115, thin $(4 \mathrm{~m})$ basalt-derived conglomerates with root traces are overlain by shallow-marine to lagoonal facies. The source of these conglomerates was possibly an emergent forearc to the southwest or west.

Paralic to inner neritic sediments appear at Sites 1109 and 1115 at approximately the same time $(>5.54$ and $<8.6 \mathrm{Ma})$. Shallow-water deposition was followed by Pliocene-Pleistocene deeper-water hemipelagic and turbidity current deposition with discrete episodes of volcanic ash and volcaniclastic turbidite input. In addition, the two sites (Sites 1114 and 1116) on the uplifted footwall (Moresby Seamount) include proximal turbiditic and debris-flow deposition related to Pliocene rifting of the Trobriand forearc.

\section{METHODS}

Of 250 thin sections examined for sediments and rocks recovered from Leg 180, 119 sand/sandstone samples were point counted from Sites $1108,1109,1114,1115,1116,1118$, and 1112. In an attempt to eliminate compositional differences between samples arising from factors other than changes in provenance, most samples point counted were of medium- to coarse-grained sand grade (average grain size $=$ $0.250-1.00 \mathrm{~mm}$ ). Where such samples were unavailable, material in the fine sand range was used. All samples were air dried, set in epoxy, and ground to $30 \mu \mathrm{m}$ in thickness. To minimize further uncertainties associated with grain-size variation, the Gazzi-Dickinson point-counting 
technique was employed (e.g., Dickinson, 1970; Zuffa, 1980; Ingersoll et al., 1984). The above approach differs from more traditional methods in that mineral grains of sand size $(>0.0625 \mathrm{~mm})$ that occur within larger rock fragments are counted as the minerals concerned rather than as larger rock fragments. The Gazzi-Dickinson method divides volcanic lithic fragments into various textural types (Dickinson, 1970), which is especially significant in magmatic arc settings where volcaniclastic components may constitute a large percentage of the sand fraction. Further divisions within the volcanic clasts were made on the nature of the intersertal material and glass color under plane-polarized light.

Reworked sedimentary rock clasts from within the formation were not counted in the modal analyses. Five hundred points per thin section were counted using an automatic digital point counter to determine the proportions of the components. Grid spacings were used that maximized the coverage of the thin sections and were larger than the maximum grain size. For modal analysis purposes, grains were divided into various compositional categories. These and derived parameters used in this study are listed in Table T1 and discussed below. Raw pointcounted data and derived parameters for all samples are listed in Tables $\mathrm{T} 2$ and $\mathrm{T} 3$.

The nature and chemistry of minerals was confirmed on selected polished sections by electron probe microanalysis. This being a methodology not directly inherent to the purpose of this specific paper, the microprobe data are not reported or discussed here.

\section{OVERVIEW OF SAND/SANDSTONE GRAIN TYPES}

In this study, the term "sand" is used for unconsolidated sediment composed of sand-sized grains, and "sandstone" is used to describe its consolidated equivalent. Sand-sized grains, which have been derived from preexisting rocks, will be described herein as detrital. Sand and sandstones are described as framework- or matrix-supported based on the amount of matrix, "matrix" being defined as detrital material with an average diameter of $<30 \mu \mathrm{m}$ (Dott, 1964). Framework-supported rocks contain $<15 \%$ matrix, whereas matrix-supported rocks have $>15 \%$. The sandstones and sands were further divided on the grounds of their relative proportions of feldspar and lithic and bioclastic particles (Table T3; Pl. P1, figs. 1-6). In the text where the terms abundant, common, rare, and trace are used to describe relative proportions of constituents of sands/sandstones, they are based on the following: abundant $=51 \%-100 \%$, common $=11 \%-50 \%$, rare $=1 \%-10 \%$, and trace $=<1 \%$.

\section{Detrital Minerals}

\section{Quartz}

Detrital quartz grains are either present in only trace amounts or absent in the sand and sandstones. Grains range from rounded to angular and strained to unstrained. They are colorless and commonly include trails of tiny fluid inclusions. Quartz also occurs as intergrowths with feldspar in granitic grains and rarely as phenocrysts within felsic volcanics. Polycrystalline quartz aggregates (made up of quartz grains $<0.0625 \mathrm{~mm}$ ) and vein quartz are observed in a few samples.
T1. Abbreviations used for sands and sandstones, p. 46.

$\overline{\text { T2. Raw point-count data, p. } 47 .}$

T3. Recalculated point-count data, p. 47.

P1. Sands and sandstones of the Woodlark rift, p. 49.

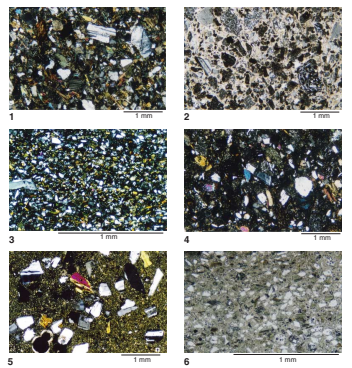




\section{Feldspar}

Detrital feldspars occur in all samples. Except for those grains that show multiple twinning or zoning, it is generally not possible to distinguish between plagioclase and alkali feldspar microscopically. Staining tests with sodium cobaltinitrite indicated the presence of only trace amounts of potassium feldspar. Therefore, the feldspars are separated into (1) untwinned feldspar and (2) twinned and zoned feldspar (Pl. P2, fig. 4). The latter is assumed to be plagioclase, as no cross-hatch twinning characteristic of microcline is observed. Some feldspar grains are fresh and unaltered, whereas others are partially replaced by secondary minerals, including white mica, albite, calcite, and clay minerals. Some of the feldspar shows myrmekitic intergrowths of plagioclase and quartz (e.g., Sample 180-1115C-26R-1, 8-9 cm). Apatite prisms occur rarely in feldspar grains (e.g., Sample 180-1108B-23R-3, 35-36.5 cm).

\section{Mica}

Detrital biotite is present in the majority of samples. It occurs as mostly brown and green cleavage flakes. In addition to occurring as discrete detrital grains, it is observed as phenocrysts within volcanics, intergrown with quartz and feldspar in granitic fragments, and as aligned plates in schist grains. Secondary calcite growth along biotite cleavage is common (Pl. P2, fig. 2). Smaller, less common muscovite laths occur as discrete detrital grains and as aligned laths in the schist grains. Pyrite blebs occur along the cleavage planes of some muscovite grains (e.g., Samples 180-1109C-24X-CC, 18-20 cm, and 180-1108B-5R-CC, 6-8 $\mathrm{cm})$.

\section{Amphibole and Pyroxene}

Clinopyroxene and hornblende grains, in addition to being constituent minerals of volcanic lithic grains, occur as discrete subhedral to euhedral grains. Under plane-polarized light the clinopyroxene is mostly colorless, whereas the hornblende grains are green or, less commonly, red/brown in color. Clinopyroxene identified is all calcic and is probably dominantly augite, although some diopside may be present (Cortesogno et al., this volume). Detrital grains composed entirely of aggregates of clinopyroxene or hornblende crystals are probably derived from glomeroporhyritic phenocrysts, observed within lithic volcanic detritus (e.g., Samples 180-1108B-27R-5, 61-63 cm, and 1801115C-29R-1, 72-73 cm) (Pl. P2, fig. 3). Rarely, clinopyroxene grains have been altered to amphibole (Sample 180-1108B-27R-5, 61-63 cm). Grains of hornblende and clinopyroxene in some samples exhibit brown irregular iron oxide rims (e.g., Sample 180-1114A-28R-CC, 3-7 $\mathrm{cm})$. Clinopyroxene grains are commonly twinned and zoned. Green hornblende forms phenocrysts within felsitic and colorless vitric volcanic fragments, whereas brown hornblende forms phenocrysts within the lathwork and brown vitric volcanic grains. Green hornblende is intergrown with feldspar and quartz in granitic fragments (e.g., Sample 180-1108B-30R-1, 42-44 cm). Actinolite is present in trace amounts (e.g., Samples 180-1108B-32R-2, 126-128 cm, and 180-1115C-29R-1, 72-73 cm) (Pl. P3, fig. 6).
P2. Mineral grains, p. 51.

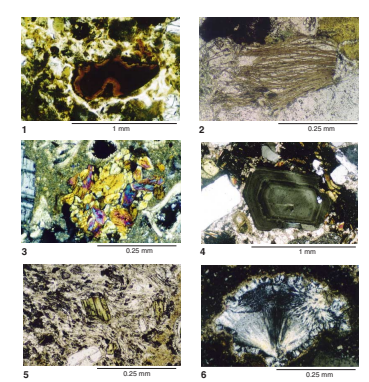

P3. Metamorphic and serpentinite lithic fragments and mineral grains, p. 53.

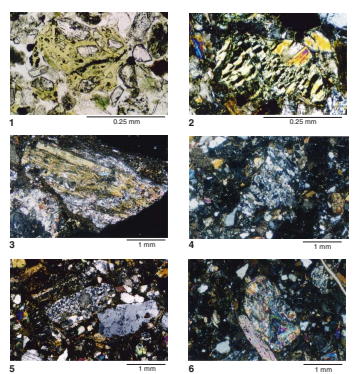




\section{Other Mineral Components}

Goethite concretions (Pl. P2, fig. 1) are numerous in Sample 1801109D-44R-1, 6-8 cm, where they form $26.5 \%$ of the framework components. These were interpreted by Robertson et al. (2001) as bog iron ore. Rare detrital aggregates of prehnite and pumpellyite are present (e.g., Sample 180-1116A-6R-1, 9-11 cm). Trace amounts of detrital epidote and zircon grains are present, with the former occurring as clusters in some samples (e.g., Samples 180-1108B-36R-3, 52-56 cm, and 180$1116 \mathrm{~A}-7 \mathrm{R}-\mathrm{CC}, 25-27 \mathrm{~cm})$. Trace amounts of chalcedony are present as fill within vugs of volcanic fragments or as detrital grains (Pl. P2, fig. 6). Olivine grains are sporadically present in trace amounts; although in Sample 180-1109C-24X-CC, 18-20 cm, they comprise 7\% of the rock. Trace amounts of spinel grains are present but were not counted in any of the samples (e.g., Samples 180-1108B-3R-CC, 0-4 cm, and 30R-1, 42$44 \mathrm{~cm}$ ). Trace to common amounts of chloritic detritus is present in many of the sandstones. Opaque minerals form minor constituents in most sandstone but were not characterized in detail. Authigenic pyrite is most common, with trace amounts of detrital chromite and magnetite also present. Pyrite occurs as framboids and disseminated grains. It is commonly associated with foraminifer tests, vitric volcanic fragments, carbonaceous detritus, and detrital mica grains. Dendritic magnetite growths are observed within dolerite clasts (Pl. P4, fig. 2).

\section{Rock Fragments}

\section{Volcanic}

Following Dickinson (1970), volcanic lithic grains are subdivided into vitric, felsitic, microlitic, and lathwork. In this study we further divided vitric (glass) fragments according to their color as viewed under plane-polarized light (ie., colorless [Pl. P5, fig. 1] or brown [including tan, brown, and black] [Pl. P5, figs. 2, 3]). The vitric category includes fragments of colorless pumice, colorless glass shards, pipe-vesicle and bubble-wall fragments, and tan, brown, and black glass of variable vesicularity. In some of the samples, the glass shows incipient devitrification. Zeolitized glassy fragments are rarely present (e.g., Sample 180$1118 \mathrm{~A}-36 \mathrm{R}-3,52-56 \mathrm{~cm}$ ). Some brown vitric fragments are altered to palagonite. Calcite and chlorite are observed replacing both brown and colorless vitric fragments. Large colorless pumiceous vitric fragments contain phenocrysts of green hornblende, plagioclase, biotite, and, rarely, clinopyroxene (Pl. P2, fig. 5). Brown vitric fragments commonly contain sparse phenocrysts of plagioclase, red to brown hornblende, biotite, and, rarely, clinopyroxene. Rare relict fiamme (elongate, flattened pumice) and calcite amygdales are present in a few brown vitric grains.

Microlitic volcanic lithic fragments contain variable amounts of feldspar microlites that commonly show a trachytic texture. Microlitic fragments are further divided into hyalopilitic (glassy) or pilotaxitic (holocrystalline) according to the nature of their groundmass (Pl. P5, figs. 4-6). The hyalopilitic grains have been further divided according to glass color. Microlitic clasts are plagioclase-, rarely biotite-, hornblende-, and/or clinopyroxene-phyric.

Lathwork volcanic fragments are characterized by plagioclase laths with intersertal brown or colorless glass and/or, rarely, intergranular clinopyroxene (Pl. P4, figs. 1-4). The intersertal glass in some grains is chloritized. Some lathwork grains are plagioclase-, clinopyroxene-, and
P4. Volcanic and plutonic lithic fragments, p. 55.

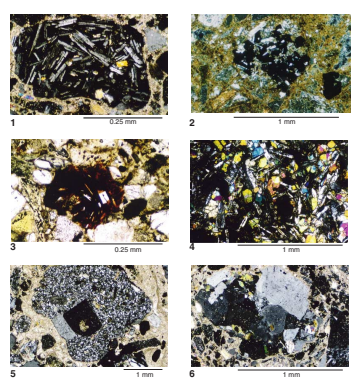

P5. Volcanic lithic fragments, p. 57.

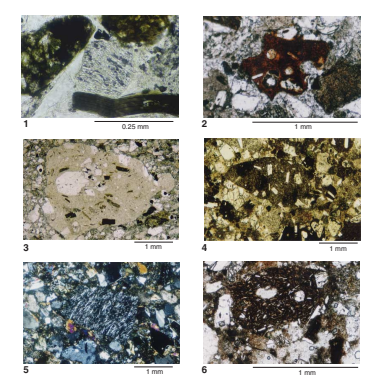


hornblende-phyric. The hornblende is commonly reddish to brown in color. Glomeroporhyritic clusters of clinopyroxene are present in a few lathwork grains. Plumose feldspar dominates some lathwork lithic fragments (Sample 180-1115C-30R-CC, 10-12 cm).

Felsitic volcanic fragments are mostly porphyritic with euhedral to subhedral feldspar and/or, rarely, quartz phenocrysts set in a microcrystalline groundmass of quartz and feldspar (Pl. P4, fig. 5). Phenocrysts of biotite and hornblende are commonly present. Feldspars are commonly replaced by white mica, albite, and/or calcite.

\section{Metamorphic Fragments}

Schist and gneiss grains form quartz-feldspar aggregates with a foliation defined by aligned flakes of mica, rarely aligned hornblende prisms, and elongate quartz and feldspar crystals (Pl. P3, figs. 4, 5). The clasts are cut by rare epidote and chlorite veins (Pl. P3, fig. 3). Feldspar within some clasts is altered to albite; prehnite and pumpellyite are also present in some grains (e.g., Samples 180-1108B-14R-1, 97-99 cm). Large sand-sized quartz and feldspar crystals within the otherwise microcrystalline aggregates are interpreted as relict phenocrysts (Pl. P3, fig. 5). A continuous range of variation from felsitic volcanic fragments and metamorphosed felsic volcanics is present. Calcareous schist fragments initially reported by Taylor, Huchon, Klaus, et al. (1999) are reinterpreted here as detrital mica grains with authigenic calcite growths along cleavage planes (Pl. P2, fig. 2).

\section{Serpentinite}

Serpentinite grains are distinctive because of their green-yellow and black lattice texture and high degree of roundness (Pl. P3, fig. 2). These grains commonly have abundant internal opaque mineral grains and rare relict olivine and pyroxene crystals (e.g., Samples 180-1108B-3RCC, $0-4 \mathrm{~cm}$, and 30R-1, 42-44 cm) (Pl. P3, fig. 1). Brown iron oxide rims occur around a few of the serpentinite grains. Serpentinite grains have been included in the metamorphic rock fragments category, although they probably formed under temperature conditions lower than those of the schist and gneiss fragments.

\section{Plutonic Fragments}

Plutonic fragments are uncommon. They are mainly rounded to angular grains of intergrown anhedral feldspar and quartz derived from granitic rocks (Pl. P4, fig. 6), although grains composed almost entirely of feldspar may have been derived from less silicic rocks. A number of grains contain hornblende and biotite. Graphic textures are observed in few of the fragments.

\section{Matrix and Cement}

Matrix is principally composed of tiny detrital fragments of volcanic glass, feldspar, mica, and clay minerals (including chlorite, illite, smectite, and kaolinite). Sparry calcite is the most common cement, but chlorite, smectite, and other clay minerals are also contributors. Abundant microfossils (i.e., planktonic foraminifers, coccoliths, siliceous sponge spicules, and radiolarians) are present in the matrix. 


\section{Bioclastic Detritus}

Two categories of carbonate detrital grains were counted: (1) skeletal grains, which included fragments of planktonic and benthic foraminifers, coralline algae, shell, bryozoans, echinoderm plates, bivalves, and gastropods; and (2) carbonate aggregates, which include micritic detrital aggregates of uncertain origin. Recrystallized limestone fragments are included in the second category (e.g., Sample 180-1108B-24R-3, 39$41 \mathrm{~cm})$.

Detrital carbonaceous fragments range from brown to black in color. Disseminated and framboidal pyrite of inferred authigenic origin occurs within the carbonaceous fragments.

\section{SANDSTONE MODAL COMPOSITION}

Discussion of significant components of sands and sandstones from individual drill sites beginning with northern rift margin and rift sites (Sites 1115, 1109, 1118, and 1108) follows. The Moresby Seamount sites (Sites 1114, 1112, and 1116), which are more tectonically deformed, less well dated, and difficult to correlate with the regional stratigraphy, are discussed subsequently. Sand and sandstone compositions are described in ascending stratigraphic order. Point-count data were recalculated as ratios of framework to interstitial material (cement and matrix) (Table T2) and plotted against depth to illustrate the compositional characteristics and downhole variation of the sands and sandstones from each site. These data were also plotted against age to allow comparison between sites. The age constraints used are taken from shipboard biostratigraphic and magnetostratigraphic analysis (Taylor, Huchon, Klaus, et al., 1999), as modified by postcruise studies (Resig et al., in press; K. Takahashi, pers. comm., 2000) (Fig. F4). The timescale is that of Berggren et al. (1995).

\section{Northern Rift Margin and Rift Basin (Sites 1115, 1109, 1118, and 1108)}

\section{Site 1115}

The succession cored at Site 1115 on the northern rift margin consists of $802.5 \mathrm{~m}$ of sediments (Fig. F5), which includes the only recovered interval of Trobriand forearc sediments (middle Miocene) as well as the unconformably overlying upper Miocene-Pleistocene rift succession. Twelve lithologic units were recognized, from which 23 samples were point counted between depths of 17.47 and 698.70 meters below seafloor (mbsf) (Tables T2, T3; Fig. F6). The middle Miocene, mainly turbidite succession (Units XI and XII), accumulated at bathyal depths in the inferred forearc basin (Taylor, Huchon, Klaus, et al., 1999). A feldspathic sandstone (Unit XII; Sample 180-1115C- 44R-2, 112-113 cm) and a bioclastic sandstone (Unit XI; Sample 180-1115C-35R-1, 85-88 $\mathrm{cm})$ were point counted. Detrital ferromagnesian minerals present within the feldspathic sandstone include biotite clinopyroxene and amphibole. Felsitic and colorless vitric volcanics are the only lithic fragments present. The bioclastic sandstone contains common skeletal carbonate detritus (foraminifers, shell fragments, coralline algae, and bryozoans) and sparry calcite cement. Detrital clinopyroxene and biotite are the only ferromagnesian minerals present, but the rock also
F4. Age-depth chart, p. 28.

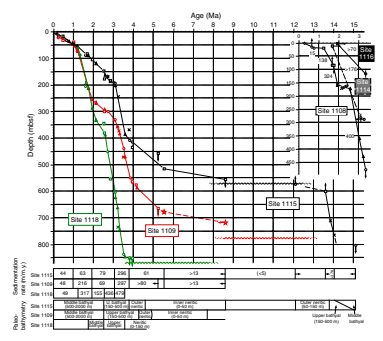

F5. Summary of the sedimentary succession, p. 29.

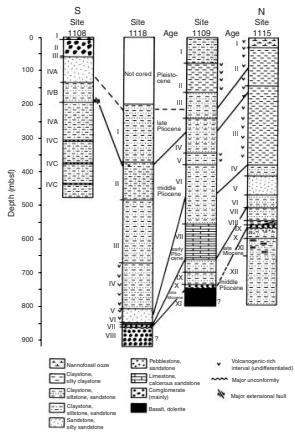

F6. Downhole variation diagrams, Site 1115, p. 30.

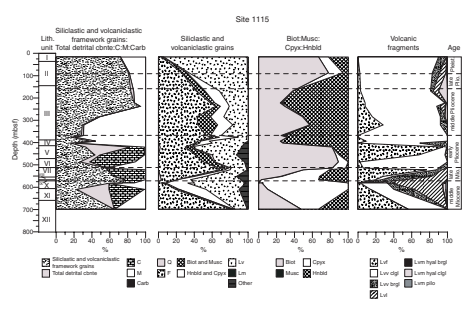


contains, in decreasing order of abundance, lathwork, colorless and brown vitric, felsitic, and microlitic volcanic fragments.

Unit X, of middle Miocene age, accumulated in a neritic setting and forms the top of the forearc succession (Taylor, Huchon, Klaus, et al., 1999). Three lithic sandstones were point counted from this unit. Lathwork fragments dominate the lithic detritus. Colorless and brown vitric fragments are present with the former more dominant except in the stratigraphically highest sandstone. Rare microlitic volcanic fragments are present. Detrital clinopyroxene is common, but detrital biotite is rare or absent. Trace amounts of chloritic detritus occur throughout the sandstones of Unit X.

Unit IX, considered to be an upper Miocene succession deposited in a high-energy shallow-marine or fluvial setting, unconformably overlies Unit X, as the stratigraphically lowermost unit of the Woodlark rift basin at Site 1115 (Taylor, Huchon, Klaus, et al., 1999). A sandstone point counted from this unit is calcite cemented and dominated by lathwork detritus. Also present are rare felsitic and common, mostly brown vitric fragments. As in the stratigraphically lower sandstones of Unit $X$ and $\mathrm{XI}$, clinopyroxene is the principal detrital ferromagnesian mineral. Detrital amphibole is rarely present. A trace amount of detrital biotite was recorded. The overlying Unit VIII, of late Miocene age, is inferred to have been deposited in a lagoonal setting (Taylor, Huchon, Klaus, et al., 1999). A calcite-cemented lithic sandstone from this unit is of similar modal composition to the sandstones of Unit IX, but with brown vitric grains being the principal lithic component. Detrital ferromagnesian grains are still dominantly clinopyroxene. Rare lathwork, colorless vitric, and felsitic volcanic grains are present along with trace amounts of epidote grains.

Units VII, VI, and V, spanning the upper Miocene to lower Pliocene succession and deposited at neritic water depths, contain sedimentary structures that are suggestive of reworking under the influence of traction currents (Taylor, Huchon, Klaus, et al., 1999). Two feldspathic sandstones were point counted from Unit VII. The stratigraphically lower sediments are calcite cemented and contain lithic detritus dominated by felsitic volcanic fragments, whereas the stratigraphically higher sediments are matrix supported and contain lithic detritus dominated by colorless vitric fragments. Brown vitric fragments are present in trace amounts in both sandstones, but lathwork volcanic fragments are only present in trace amounts in the stratigraphically lower sample. A single feldspathic calcite-cemented sandstone, with rare planktonic foraminifer and trace detrital carbonate grains, was studied from Unit VI. The main detrital ferromagnesian mineral present in this sandstone is biotite with lesser amounts of clinopyroxene. The lithic fragments are mainly of the colorless vitric type with traces of felsitic grains.

A feldspathic sandstone (Sample 180-1115C-19R-CC, 8-10 cm) and a bioclastic sandstone (Sample 180-1115C-15R-3, 79-83 cm) were analyzed from Unit $\mathrm{V}$. The bioclastic material in the latter is dominated by planktonic foraminifer tests with minor shell debris. Both sandstones are calcite cemented and have a lithic detrital component dominated by felsitic volcanics and lesser colorless vitric fragments. Biotite and amphibole are present in both sandstones point counted from this Unit V, with clinopyroxene present only in trace amounts in the stratigraphically lower sample of the two sandstones.

Units IV, III, II, and I are thin-bedded, commonly graded sands and sandstones interpreted as having been deposited by turbidity currents followed by localized reworking by bottom currents (Taylor, Huchon, 
Klaus, et al., 1999). The lowermost $5 \mathrm{~m}$ of Unit IV accumulated at neritic depths, whereas stratigraphically higher rocks accumulated in bathyal depths (Taylor, Huchon, Klaus, et al., 1999). Two feldspathic matrix-supported sandstones were point counted from the lower to middle? Pliocene Unit IV. Colorless vitric fragments with lesser amounts of felsitic and brown vitric fragments dominate the lithic component of the sandstones. Detrital biotite and amphibole are present. The majority of the sands within Unit III (early? to middle Pliocene age), Unit II (late Pliocene-Pleistocene age), and Unit I (Pleistocene age) are matrix supported. The sands of Unit II and I are lithic, whereas sands from Unit III are feldspathic. Rare to trace amounts of skeletal carbonate and detrital carbonate aggregates are present in these sands. Colorless vitric fragments are the dominant lithic grains. Brown glass and felsitic and microlitic fragments are present in most of the samples. Detrital amphibole and biotite are present in all samples. The former is dominant in Unit III, whereas the latter is dominant in Units I and II. Clinopyroxene grains are present in trace amounts in all sandstones above 284.89 mbsf (Units III, II, and I), except Sample 180-1115B-19H1, 65-67 cm. In addition, trace detrital muscovite plates were observed in Sample 180-1115B-24X-5, 104-105 cm; Sample 180-1115C-31X-1, 139-141 cm; and Sample 180-1115B-10R-1, 5-7 cm.

\section{Site 1109}

At Site 1109, on the northern margin of the Woodlark rift, $773 \mathrm{~m}$ of sediments and sedimentary rocks were drilled in several holes that terminated in massive dolerite (Figs. F3, F5). Thirty samples were point counted between the depths of 26.54 and 753.66 mbsf (Tables T2, T3; Fig. F7). Unit X, IX, and VIII are undated. Units X and IX were interpreted by Taylor, Huchon, Klaus, et al. (1999) to reflect terrestrial sedimentation in a marine/fluvial to swamp setting. In a single matrixsupported lithic sandstone point counted from Unit X, goethite/limonite concretions are the dominant detrital component (Pl. P2, fig. 1). Of rare volcanic fragments, felsitic types predominate, but microlitic and colorless vitric fragments are also present. Clinopyroxene is the main detrital ferromagnesian mineral, with only a single amphibole grain being point counted. Detrital chloritic grains are rarely present. The matrix is composed of smectite and chlorite (Robertson and Sharp, this volume). No sandstone was counted from the overlying Unit IX, but sandstones in this unit are of similar composition to those of Unit X. Deposition of Unit VIII probably occurred in a lagoonal setting (Taylor, Huchon, Klaus, et al., 1999). Four matrix-supported feldspathic sandstones were point counted from this unit. Amphibole and biotite are the dominant detrital ferromagnesian minerals in the majority of samples. Detrital clinopyroxene grains occur in all. Of the rare volcanic lithic detritus, felsitic and colorless vitric fragments dominate, with trace microlitic and lathwork grains being present in Sample 1801109D-38R-2, 12-18 cm. In all samples, rare or trace amounts of carbonaceous detritus are present.

Evidence of current reworking in the sandstones within Unit VII (lower Pliocene) and paleontological evidence indicate deposition of this unit in a shallow-marine environment (Taylor, Huchon, Klaus, et al., 1999). Four calcite-cemented sandstones were studied from this unit. All are feldspathic except for the stratigraphically lowest sandstone, which is bioclastic. Detrital ferromagnesian minerals are mainly amphibole and biotite but with trace amounts of clinopyroxene present
F7. Downhole variation diagrams, Site 1109, p. 31.

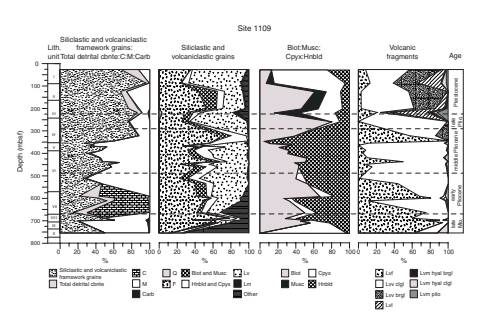


throughout. The main lithic detritus is felsitic and colorless vitric fragments, which occur in varying proportions. Trace amounts of microlitic fragments are present in some sandstones. Detrital skeletal carbonate (foraminifer, shell fragments, coralline algae, and bryozoans) predominates within the bioclastic sandstone and is common in most of the other sandstones.

Unit VI, of middle Miocene to early Pliocene age, is interpreted to show an apparently abrupt change from an inferred shallow-water environment to a bathyal quiet setting interrupted by rare, mainly highdensity turbidity currents (Taylor, Huchon, Klaus, et al., 1999). Eight matrix-supported sandstones were point counted from this unit, ranging in composition from feldspathic to lithic. Colorless vitric fragments are the dominant lithic components in the majority of sandstones. Felsitic volcanic fragments are present in rare to trace amounts in all, whereas trace amounts of microlitic and lathwork volcanic fragments are present in several. Amphibole and biotite are the dominant detrital ferromagnesian minerals, with trace amounts of clinopyroxene present in Samples 180-1109D-10R-4, 95-98 cm, and 17R-7, 34-46 cm.

All the sandstones in Unit V to Unit I were probably deposited by turbidity currents at bathyal depths (Taylor, Huchon, Klaus, et al., 1999). Two feldspathic and three lithic matrix-supported sandstones were point counted from Unit V (middle Pliocene age). In all, colorless vitric fragments are the dominant volcanic detritus. Trace amounts of microlitic, felsitic, and lathwork volcanic lithic fragments are present in some sandstones. Clinopyroxene is absent from Unit V, with amphibole and biotite the dominant detrital ferromagnesian minerals.

Three sands were point counted from the middle to upper Pliocene Unit IV, two feldspathic sands (Samples 180-1109C-28X-2, 0-3 cm, and $37 \mathrm{X}-5,106-108 \mathrm{~cm}$ ) and a lithic sand (Sample 34X-5, 106-108 cm). This unit records the first appearance of serpentinite detritus at this site, with trace serpentinite grains in Samples 180-1109C-34X-5, 106-108 $\mathrm{cm}$, and 28X-2, $0-3 \mathrm{~cm}$. Common colorless vitric fragments dominate the lithic sand, but trace amounts of microlitic and felsitic volcanics are present. Rare to trace amounts of volcanic lithic grains are present in the feldspathic sands (brown vitric, colorless vitric, and felsitic types). Biotite is the predominant detrital ferromagnesian mineral toward the top of the unit, whereas amphibole is more common toward the base. Detrital clinopyroxene grains occur in trace amounts in the stratigraphically highest sand.

Within Unit III (upper Pliocene to Pleistocene), a feldspathic (Sample 180-1109C-22X-CC, 23-23.5 cm) and a lithic (Sample 24X-CC, 18-20 $\mathrm{cm})$ sand were point counted. The sands are dominated by framework components, principally feldspar and volcanic fragments. Colorless vitric fragments and lesser brown vitric fragments are the main volcanic detritus in Sample 180-1109C-22X-CC, 23-23.5 cm. Lathwork and felsitic and microlitic volcanic fragments are dominant in the other, stratigraphically lower sandstone. Also present in the latter are rare serpentinite, rare olivine, trace schist, and rare carbonaceous detritus. Trace detrital serpentinite grains are present in Sample 180-1109C-24XCC, $18-20 \mathrm{~cm}$.

A total of three sands were point counted from Units II and I (Pleistocene). The stratigraphically lowermost sand sampled from Unit II is feldspathic and framework dominated, whereas the higher sands are matrix dominated and, although containing common feldspar, are of overall lithic composition. Colorless and brown vitric fragments are the principal lithic components present. In Sample 180-1109C-10H-3, 43- 
$45 \mathrm{~cm}$, lathwork volcanic fragments are common, with microlitic and felsitic fragments rarely present. Rare microlitc, lathwork, and felsitic volcanic fragments are present in the sand of Unit I, but only trace amounts of lathwork and felsitic fragments are present in the stratigraphically lowest sand of Unit II. All sandstones contain trace amounts of detrital serpentinite grains. Detrital biotite, clinopyroxene, amphibole, and chlorite are present in all samples. Detrital muscovite grains are present in both sandstones of Unit II. Detrital skeletal material (mostly planktonic foraminifers) and carbonate aggregates are present throughout the sandstones counted within Unit I and II.

\section{Site 1118}

Site 1118 is located $\sim 9 \mathrm{~km}$ due south of Site 1109, toward the northern margin of the Woodlark rift basin (Figs. F3, F5). From 0 to 205.0 mbsf, the site was drilled without coring. Of eight lithostratigraphic units recognized from Hole 1118A between 205.0 and 926.6 mbsf, only sandstones from Units I to $\mathrm{V}$ were point counted (Tables T2, T3; Fig. F8).

Sandstones from Unit V (lower Pliocene to middle Pliocene) and Unit IV (middle Pliocene) are of similar composition. They show clear evidence of deposition from turbidity currents and later reworking in bathyal depths (Taylor, Huchon, Klaus, et al., 1999). The sandstones are lithic and feldspathic and dominantly matrix supported. Lithic detritus is dominated by colorless vitric grains. Felsitic fragments are present in rare to trace amounts. Trace amounts of microlitic, lathwork, and brown vitric fragments are present in some sandstones. Amphibole and biotite are the dominant and, in most cases, only detrital ferromagnesian minerals present, although trace amounts of detrital clinopyroxene are present in three samples.

Units I-III are interpreted as turbidity-current deposits that accumulated at bathyal depths. They lack the evidence of reworking noted in the underlying unit (Taylor, Huchon, Klaus, et al., 1999). Eight feldspathic and lithic sandstones were sampled from Unit III (middle to upper Pliocene) between 632.49 and 493.40 mbsf. The majority of the sandstones are framework supported and contain detrital carbonate (skeletal and aggregate). Detrital biotite, clinopyroxene, and amphibole are present in all the sandstones. Clinopyroxene decreases in abundance downsection. Lathwork fragments are the principal lithic detritus in the sandstones of the stratigraphically higher part of the unit but also decrease in overall abundance downhole as do microlitic fragments, present in common to trace amounts, in the upper part of the unit but absent in some of the stratigraphically lowest sandstones. Colorless vitric fragments are present in all the sandstones but become more abundant in the stratigraphically lower part of the unit. Felsitic and vitric fragments are present in all sandstones. Brown vitric fragments were counted only in the stratigraphically higher sandstones.

Two sandstones were point counted from Unit II (middle to upper Pliocene), Sample 180-1118A-20R-3, 112-124 cm, a feldspathic matrixsupported sandstone, and Sample 180-1118A-24R-5, 105-107 cm, a lithic framework-supported sandstone. The volcanic lithic detritus in the former is composed of, in decreasing order of abundance, colorless vitric, lathwork, brown vitric, and felsitic grains. The stratigraphically lower sandstone shows an increase in volcanic fragments and the appearance of microlitic detritus. Detrital biotite, clinopyroxene, and am-
F8. Downhole variation diagrams, Site 1118, p. 32.

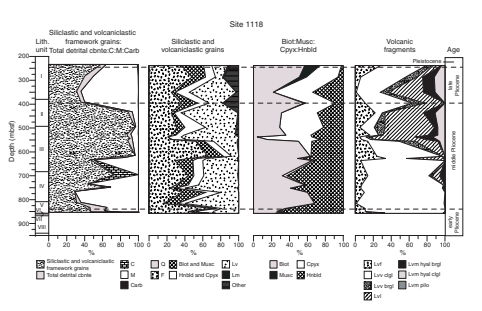


phibole are present in both sandstones, with trace amounts of muscovite only in the stratigraphically higher sample.

Three matrix-dominated sands were point counted from Unit I (middle-late Pliocene to Pleistocene age). They are feldspathic or lithic and contain rare skeletal (planktonic foraminifer) and aggregate carbonate detritus. Rare to trace amounts of carbonaceous detritus are present in the two stratigraphically higher samples. The dominant lithic detritus in all samples is volcanic, but serpentinite is also present in Samples 180-1118A-4R-CC, 17-19 cm, and 9R-1, 35-38 cm. Colorless and brown vitric, felsitic, lathwork, and microlitic grains are present, with colorless vitric types dominant in Samples 180-1118A-4R-CC, 17-19 cm, and 9R$1,35-38 \mathrm{~cm}$. Lathwork fragments are the most common volcanic detritus in Sample 180-1118A-15R-5, 141-142 cm. Muscovite is present in the two stratigraphically highest sands. Detrital biotite, clinopyroxene, and amphibole are present in varying amounts in all samples.

\section{Site 1108}

Site 1108 is located near the base of the northern slope of the Moresby Seamount (Figs. F3, F5) and was positioned with the aim of penetrating the major extensional detachment fault defining the southern margin of the Woodlark rift. Four units were recognized within the succession recovered from Site 1108, which consists of 485.2 m of sediments and sedimentary rocks of middle Pliocene to late Pleistocene age (Fig. F5). Unit IV, of middle Pliocene to Pleistocene age, is well lithified. It shows sufficient variation in the relative abundances of different sedimentary rocks to allow recognition of three subunits: Subunit IVA, dominated by medium- to coarse-grained sediments, Subunit IVB, mostly fine grained with rare medium- to coarse-grained sediments, and Subunit IVC, mainly composed of conglomerate. Sandstones from Unit IV are considered to have been deposited by turbidity currents in bathyal depths (Taylor, Huchon, Klaus, et al., 1999). There is some suggestion that reworking by bottom currents has taken place. The three coarser-grained intervals of conglomerate that form Subunit IVC are interpreted as high-density turbidity-current or debris-flow deposits. The stratigraphically higher part of the succession at this site (Units I-III) comprises calcareous hemipelagic sediments and lower breccias composed of heterogeneous clasts inferred to have been derived from upslope on the Moresby Seamount (Robertson et al., 2001).

A total of 19 sandstones were point counted from this site (Tables T2, T3; Fig. F9), the majority (17) from Unit IV. The remaining samples are two sandstone pebbles from Unit II. Sandstones from Unit IV are calcite cemented, of lithic or feldspathic composition, and mostly framework supported. They all display a similar composition, except for the appearance of metamorphic and/or serpentinite detritus in all samples from $333.94 \mathrm{mbsf}$ and higher. The sandstones contain felsitic, colorless vitric, brown vitric, and microlitic volcanic lithic fragments in a range of relative abundances. Muscovite, biotite, clinopyroxene, and amphibole are present in all except Sample 180-1108A-49R-CC, 5-6 cm, from close to the base of the unit, in which only biotite and clinopyroxene are present.

Two sandstone pebbles from Unit II are a lithic sandstone (Sample 180-1108B-3R-CC, 0-4 cm) and a feldspathic sandstone (Sample 1801108B-5R-CC, 6-8 cm). Both are cemented by calcite, framework supported, and have a similar composition to the sandstones within the stratigraphically higher part of Unit IV (<380.84 mbsf).
F9. Downhole variation diagrams, Site 1108, p. 33.

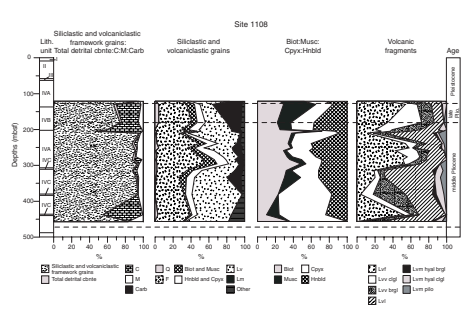




\section{Comparison between the Northern Rift Sites (Sites 1108, 1109, 1115, and 1118)}

The sands and sandstones from the northern rift sites range from feldspathic to lithic sandstones and include both framework- and matrix-supported varieties (Fig. F10). Most lower Pliocene samples counted from Sites 1115, 1109, and 1118 are cemented by calcite and contain detrital carbonate. Upper to middle Miocene sandstones from Site 1115 are mostly calcite cemented, in contrast to the upper Miocene sandstones from Site 1109. Compared to the other northern sites of the Woodlark rift, the middle to upper Pliocene sandstones sampled from Site 1108 are unusually cemented by calcite. A common feature of Sites 1108,1118 , and 1109 is the appearance of metamorphic and serpentinite lithic detritus in sandstones of middle to late Pliocene age (Fig. F11). The earliest recorded serpentinite detritus within the sandstones is estimated to have occurred at $2.98 \mathrm{Ma}$ at Site 1108 and $2.91 \mathrm{Ma}$ at Site 1109. Serpentinite detritus was not observed from Site 1118 until $1.93 \mathrm{Ma}$, and neither metamorphic nor serpentinite lithic detritus was recorded from Site 1115. Detrital schist and gneiss grains occur in greatest abundance at Site 1108, where they appear at the same level as does serpentinite detritus. The only other northern site where schist and gneiss were observed is Site 1109 (Sample 180-1109C-24X-CC, 18-20 $\mathrm{cm}$ [217.88 mbsf; $1.78 \mathrm{Ma}]$ ). The distribution of detrital muscovite flakes parallels the distribution of metamorphic and serpentinite, with an increasing abundance in the progressively younger upper Pliocene to Pleistocene samples from Sites 1108, 1118, and 1109. However muscovite is also present within upper Miocene sandstones at Site 1115.

Detrital ferromagnesian minerals show several systematic changes at the northern sites (Fig. F12). The oldest (lower Miocene) sandstone from Unit XII at Site 1115 contains minor amounts of biotite, amphibole, and clinopyroxene, but in the upper middle Miocene and lower upper Miocene sandstones, clinopyroxene dominates and, in some samples, is the only ferromagnesian mineral present. A parallel trend is shown by the volcanic fragments at Site 1115, with felsitic and colorless vitric volcanic fragments dominating the oldest sandstone and lathwork fragments increasing rapidly in abundance in overlying sandstones (Fig. F13). The abundance of clinopyroxene grains begins to decrease in the upper upper Miocene as the quantity of detrital biotite and amphibole grains increase. The change is accompanied by an increase in felsitic and a decrease in lathwork detritus. By the middle Pliocene, clinopyroxene has nearly disappeared from all the sandstones within the northern rift sites but clinopyroxene reappears in the upper middle Pliocene sediments and becomes more abundant in the Pleistocene, especially in sandstones of Site 1109 (Fig. F12). Colorless vitric and felsitic fragments dominate the volcanic detritus within sands and sandstones of the upper upper Miocene and younger in the northern sites (Fig. F13). Lathwork and microlitic fragments increase from the upper middle Miocene upward, which correlates with an increase in detrital clinopyroxene grains.
F10. Ratios of framework grains:detrital carbonate:carbonaceous detritus:cement:matrix, p. 34 .

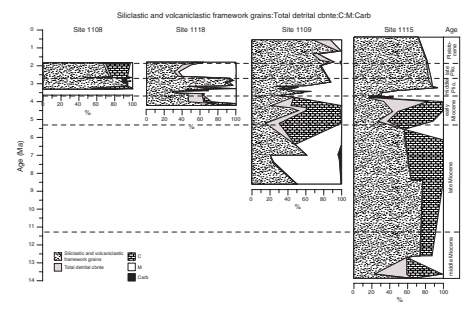

F11. Ratios of siliciclastic and volcaniclastic grains, p. 35 .



F12. Ratios of biotite:muscovite:clinopyroxene:amphibole, p. 36.

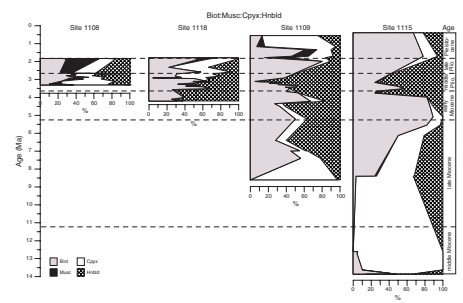

F13. Ratios of volcanic rock fragments, p. 37.

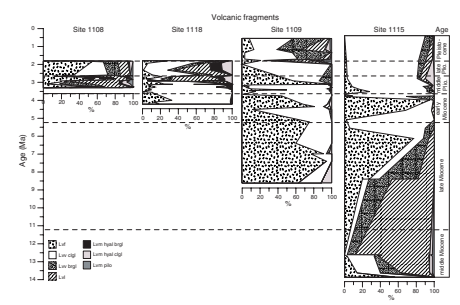




\section{Moresby Seamount Sites (Sites 1114, 1112, and 1116)}

\section{Site 1114}

At Site 1114, located near the northeastern edge of Moresby Seamount, almost $286 \mathrm{~m}$ of sediments and sedimentary rocks was recorded, separated by a low-angle extensional fault from metamorphic basement rocks (metadolerite) (Figs. F3, F14). Twelve samples were point counted from four of the seven lithostratigraphic units recognized (Units V, IV, III, and II) (Tables T2, T3; Fig. F15). These units were inferred to have been deposited by turbidity currents in bathyal depths (Taylor, Huchon, Klaus, et al., 1999). A framework-supported lithic sandstone from Unit V (middle Pliocene), which lies directly above a tectonic breccia (Unit VI), contains predominantly lathwork grains, although microlitic, felsitic, brown vitric, and colorless vitric volcanic fragments are also present. Clinopyroxene is the dominant detrital ferromagnesian mineral along with minor detrital biotite and chloritic grains. Two lithic sandstone samples from Unit IV (middle Pliocene) have a similar composition but also show trace amounts of detrital muscovite.

Seven sandstones sampled from Unit III (middle to upper Pliocene) include both feldspathic and lithic sandstones, which range from framework to matrix supported. Sandstones from Subunit IIIA (Samples 180-1114A-14R-1, 106-108 cm, and 15R-1, 46-48 cm) contain abundant detrital skeletal carbonate (foraminifer, algae, and shell fragments) and detrital carbonate aggregates. Sandstones counted from Unit III show a similar composition to underlying sandstones, save for an increase in detrital biotite and colorless vitric or brown vitric volcanic fragments toward the top of the unit. Serpentinite detritus occurs in one of these sandstones (Sample 180-1114A-9R-2, 15-17 cm [76.03 mbsf]). Two framework-supported feldspathic sandstones from Unit II (upper Pliocene) differ from the majority of the underlying sandstone in that colorless vitric grains make up the majority of the lithic fragments and there is an accompanying increase in the abundance of detrital biotite. Carbonaceous detritus is present within the sandstones of Unit II and the stratigraphically highest sandstone of Unit III.

\section{Site 1116}

Site 1116 is located on the southern flank of the Moresby Seamount, $8 \mathrm{~km}$ south of Site 1114 (Figs. F2, F3). Three lithostratigraphic units were recognized at this site, which was drilled to $158.90 \mathrm{mbsf}$ (Fig. F14). Unit III accumulated during the Pliocene at middle bathyal depths (Taylor, Huchon, Klaus, et al., 1999). Within this unit, thick-bedded sandstones that commonly show a basal inverse-graded interval were interpreted as deposits from high-density turbidity currents, whereas other sandstones in the unit were interpreted as deposits from lowerdensity "classical" turbidites (Taylor, Huchon, Klaus, et al., 1999). Seven lithic and feldspathic sandstones from between 152.38 and 81.96 mbsf were point counted from this unit (Tables T2, T3; Fig. F16). All are framework supported except for Sample 180-1116A-17R-2, 53-55 cm, and all are calcite cemented. In the lower part of the unit, the lithic detritus is dominated by lathwork and brown vitric fragments, whereas felsitic fragments become more dominant in stratigraphically higher sandstones. Microlitic and colorless vitric fragments are present in rare
F14. Summary of the sedimentary succession, p. 38.

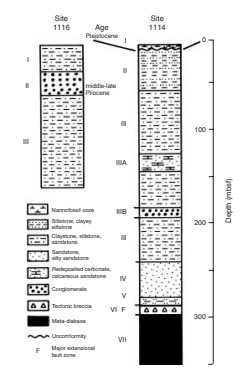

F15. Downhole variation diagrams, Site 1114, p. 39.

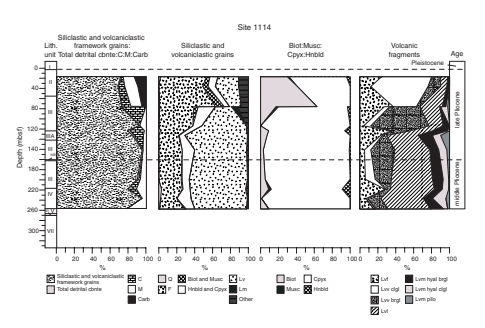

F16. Downhole variation diagrams, Site 1116, p. 40.




and trace amounts throughout Unit III. Clinopyroxene is the principal detrital ferromagnesian mineral throughout Unit III, except for Sample $180-1116 \mathrm{~A}-13 \mathrm{R}-4,51-54 \mathrm{~cm}$, in which biotite is more abundant. Grains of serpentinite are recorded in two sandstones from Unit III (Samples 180-1116A-11R-1, 16-19 cm [81.96 mbsf], and 16R-1, 103-107 cm [131.03 mbsf]).

Unit II, of Pliocene age, contains paraconglomerate intercalated with sandstone. These rocks are considered to be deepwater debris-flow and turbidity-current deposits (Taylor, Huchon, Klaus, et al., 1999). A single matrix-supported lithic sandstone point counted from this unit contains rare detrital serpentinite and schist grains. The latter contain epidote and chlorite veins, together with prehnite and pumpellyite (Sample 180-1116A-6R-1, 9-11 cm [42.49 mbsf]) (Pl. P3, fig. 3). Detrital prehnite and pumpellyite grains occur in the sandstone. Lathwork fragments are the most abundant lithic detritus, which also includes, in order of decreasing abundance, felsitic, microlitic, colorless, and brown vitric grains. Clinopyroxene is the most abundant detrital ferromagnesian mineral, with subordinate biotite. A single detrital muscovite plate was noted.

A lithic and a feldspathic sandstone from Unit I (upper Pliocene) are both framework supported and cemented by calcite. They contain similar lithic detritus to the sandstones in Unit II with lathwork and felsitic detritus predominating. Clinopyroxene is the principal detrital ferromagnesian mineral, with subordinate biotite, rare clinopyroxene, and trace amphibole. The stratigraphically higher of the sandstones contains rare detrital muscovite, serpentinite, and schist grains.

\section{Site 1112}

The Pleistocene deposits of Site 1112, as far as can be determined from the minimal recovery, probably comprise a talus deposit on the northern side of Moresby Seamount (Taylor, Huchon, Klaus, et al., 1999). Two sandstone pebbles from this site were point counted, a lithic framework-supported sandstone (Sample 180-1112A-3R-1, 2-5 cm [20.52 mbsf]) and a feldspathic framework-supported sandstone (Sample 180-1112A-9R-CC, 25-27 cm [78.15 mbsf]). Lathwork grains are the principal lithic component in both pebbles. Other volcanic detritus includes colorless vitric, brown vitric, microlitic, and felsitic types. Clinopyroxene is the most common detrital ferromagnesian mineral, and trace amphibole is also present. Detrital biotite is common in the stratigraphically higher pebble.

\section{Comparison between Moresby Seamount Sites (Sites 1114 and 1116)}

The upper Pliocene to Pleistocene sandstones from Sites 1116 and 1114 are feldspathic, whereas the older sandstones are dominated by lithic volcanic detritus (Fig. F17). The majority of sandstones from these sites are partially to well cemented by calcite. Carbonaceous material is only observed in the upper Pliocene to Pleistocene sandstones of Site 1114. For the Pliocene and Pleistocene time interval, either felsitic or lathwork grains alternate as the principal lithic component. Microlitic, colorless vitric, and brown vitric volcanic grains occur in most of the sandstones. The first occurrence of serpentinite at Site 1116 is estimated to have occurred at $\sim 3.05 \mathrm{Ma}$, but at Site 1114 , it is only observed in a single sandstone of $\sim 2.01-\mathrm{Ma}$ age (Fig. F17). Schist and
F17. Downhole variation diagrams, Moresby Seamount sites, p. 41.

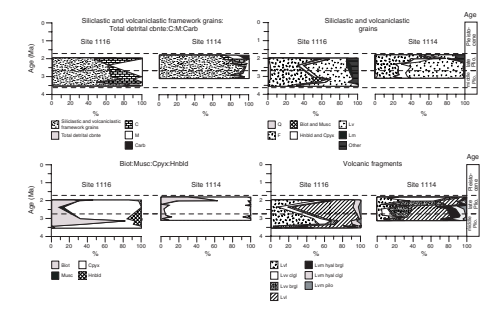


gneiss grains are only present at Site 1116 in sandstones estimated at $\sim 2.40$ and $\sim 2.00 \mathrm{Ma}$ in age. Clinopyroxene is the dominant detrital ferromagnesian mineral at these sites, except within sandstones estimated as $\sim 3.17 \mathrm{Ma}$ (Site 1116) and $2.00 \mathrm{Ma}$ (Site 1114) age, in which biotite is dominant. Chloritic detritus is more abundant within upper Pliocene to Pleistocene sandstones. Sandstone pebbles recovered from Site 1112 are of similar composition to those sandstones of Sites 1114 and 1116, which have a detrital lithic component dominated by lathwork grains (Fig. F17).

\section{DISCUSSION}

The use of petrographic discrimination diagrams such as those of Dickinson et al. (1983) to distinguish the tectonic setting of sediment source areas is well established. Interpretation of these diagrams is based on the assumption that the nature and availability of source lithologies is intimately related to tectonic processes controlling the development of a basin margins. Problems with interpretation can arise if much detritus was derived from a tectonically unrelated setting (e.g., older orogen). Also, the method implicitly assumes an ideal tectonic arrangement (e.g., similar to the type area in the western United States [arc, forearc basin, and trench]). However, the Woodlark Basin is unusual in several respects, notably the presence of arc-type volcanics well out into the forearc region, which complicates the interpretation of petrographic results.

The most commonly used diagram is the QFL plot with the provenance fields of Dickinson et al. (1983) superimposed (Fig. F18). The dominance of feldspar and volcanic lithic grains and the rarity to complete absence of quartz ensures the sandstones and sands plot within the magmatic arc field. Further division on the basis of the abundances of feldspar and lithic fragments results in the majority of the sandstones (four of five) from the upper Miocene Trobriand forearc basin plotting within the undissected-magmatic arc field, which confirms the validity of this model (Fig. F18). The sands and sandstones of the Woodlark rift basin, when divided according to these same abundances, plot within the undissected- to transitional-magmatic arc fields (Fig. F18). This highlights the evolving nature and the complex local sediment sources and pathways of the Woodlark rift basin between the late Miocene to Pleistocene, which will be discussed below, according to the stages of tectonic evolution proposed for the basin by Robertson et al. (2001) (Figs. F19, F20).

\section{Middle Miocene}

Southwestward subduction of oceanic crust of the Solomon Sea initiated the Miocene-Holocene Trobriand volcanic arc (Lock et al., 1987; Davies et al., 1987), which is well developed on the Papuan Peninsula. The front of the Trobriand Arc was located in the vicinity of the Moresby Seamount and D'Entrecasteaux Islands (Robertson et al., 2001). This is supported by drill evidence, with a middle Miocene forearc sequence recovered only at the most northern site (1115). Based on seismic stratigraphic records (Taylor et. al., 1995), Robertson et al. (2001) (Fig. F20) further suggested that the cored interval here represents only the upper section of a kilometer-thick forearc succession. The composition of sandstone near the base of the cored interval is domi-
F18. QFL plots of Leg 180 sandstones and sands, p. 43.

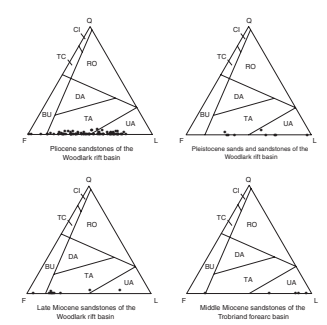

F19. Major changes in provenance and tectonic setting, p. 44 .

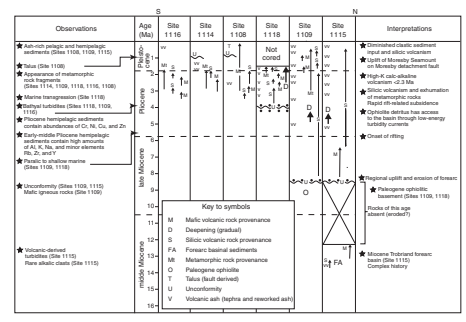

F20. Inferred paleotransport directions, p. 45.




nated by colorless vitric and felsitic volcanic lithic fragments. Biotite and amphibole are the dominant detrital ferromagnesian minerals. This suggests that volcanics of intermediate to silicic composition were the main source of detritus. In addition, the presence of alkalic volcanic clasts in a packstone of middle Miocene age was reported by Cortesogno et al. (this volume). The lithic detritus within the remainder of the sandstones of the Trobriand forearc sequence is dominated by lathwork grains, and clinopyroxene is the dominant and, in some cases, the exclusive detrital ferromagnesian mineral. Felsitic detritus is present in most sandstones. Therefore, the sandstone detritus during the middle Miocene was dominantly sourced from pyroxene basalts and minor silicic volcanics (Fig. F19). Calc-alkaline volcanics of the Trobriand Arc (Lock et al., 1987; Davies et al., 1984) to the south are thought to be the source for this detritus (Fig. F20). However, Robertson et al. (2001) suggested that similar calc-alkaline volcanoes located within the present forearc region (e.g., Woodlark Island) (Ashley and Flood, 1981) could also have provided an additional source (Fig. F20). The presence of silicic and alkalic volcanics suggests that the contemporary Trobriand Arc had a complex volcanic history.

\section{Late Miocene}

During this period, the Trobriand outer arc/forearc was subaerially exposed and eroded and the initial sediments of the rift basin prograded northward over the forearc succession (Robertson et al., 2001). A shallowing-upward succession at Site 1115 (>5.4 Ma) culminated in emergence and erosion of an unconformity, which is overlain by an upper Miocene shallow-marine succession (Robertson et al., 2001) (Fig. F19). These authors further recognized nonmarine counterparts of these shallow-water deposits at Sites 1109 and 1118, although these remain undated. Conglomerates at Sites 1109, 1115, and 1118 contain clasts of dolerite, basalt, and gabbro (Taylor, Huchon, Klaus, et al., 1999). The dolerite is of inferred ophiolitic origin (Robertson et al., 2001). The lowermost upper Miocene sandstones at Site 1115 are dominated by lathwork grains, with clinopyroxene the most abundant and, in some samples, exclusive detrital ferromagnesian mineral. Lowermost upper Miocene sandstone from Site 1109 contains goethite/limonite concretions and chlorite and clinopyroxene as the predominant ferromagnesian minerals. The composition of the sandstones and conglomerate thus suggests a basinwide dominantly mafic volcanic (basalt to dolerite) source at this time (Fig. F19). During late Miocene time this was the exposed Trobriand forearc, which included Paleogene ophiolitic rocks (Fig. F20). Derivation from the hinterland of Papua New Guinea, including the Paleogene Papuan ophiolite belt, is unlikely as other metaophiolite rocks (e.g., serpentinite) are absent.

\section{Late Miocene-Early Pliocene}

During the late Miocene-early Pliocene, rifting led to a transition from terrestrial to marginal-marine and then shallow-marine deposition. At Sites 1109 and 1115, paralic deposits are overlain by upper Miocene-lower Pliocene lagoonal to shallow-marine rocks, whereas at Site 1118, lower Pliocene shallow-marine rocks abruptly overlie inferred upper Miocene fluvial conglomerates (Robertson et al., 2001) (Fig. F19). At Sites 1115 and 1109, the basin underwent gradual subsidence from neritic to bathyal conditions during the latest Miocene-middle Pliocene, 
whereas the marine transgression was delayed until latest early Pliocene at Site 1118 (Fig. F19). The beginning of extension was marked by a change to more explosive silicic volcanism, and the sandstones deposited during this interval were dominated by felsitic and colorless vitric grains, with amphibole and biotite the dominant detrital ferromagnesian minerals and clinopyroxene an insignificant component (Fig. F19). Mafic volcanics were still supplying some detritus to the basin, as shown by the presence of rare lathwork detritus within the sandstones and the presence of rare basalt and dolerite pebbles within shallow-marine paraconglomerate at Site 1118 (Taylor, Huchon, Klaus, et al., 1999).

Assuming sediment pathways were similar to today, it is suggested that the probable source of the Pliocene turbidites lay to the northwest (Robertson et al., 2001) (Fig. F20). In this interpretation, the main sources of ash and volcaniclastic turbidites were possibly the Amphlett Islands, Dawson Strait (e.g., Dobu Seamount), Moresby Strait, and surrounding areas where Pliocene-Pleistocene volcanic rocks occur (Smith and Milsom, 1984; Binns et al., 1987) (Fig. F20). Additional sources of volcanics could be the active Trobriand Arc volcanoes on the northern rift margin (i.e., the Luscany Islands, Trobriand Island, Woodlark Island, and Egum atoll), the eastern Papua Peninsula, and sediment reworked from the Cape Vogel Basin to the northwest (Fig. F20).

\section{Early to Late Pliocene}

During this time at Sites 1118, 1109, 1118, and 1115, sandstones were deposited at bathyal depths, except for the lowermost $5 \mathrm{~m}$ at Site 1115 , which was deposited in a neritic environment (Robertson et al., 2001) (Fig. F20). The lithic component of the sandstones that accumulated during this time at Sites 1115 and 1109 is dominantly felsitic with colorless vitric fragments. At Sites 1108 and 1118, the lithic component of the sandstone varies from rich in felsitic and colorless vitric material to rich in lathwork and microlitic grains. The sequences on Moresby Seamount at Sites 1116 and 1114 were deposited in bathyal depths and demonstrate similar changes in lithic detritus to those observed at Sites 1108 and 1118 during this period. At all sites except Site 1115, sandsized metamorphic and serpentinite detritus makes its first appearance in the late Pliocene ( 3 Ma) (Fig. F19).

The similarities in Pliocene turbidite sedimentation at Sites 1114 and 1116 on the southern margin and Site 1108 near the rift depocenter farther north have been taken to suggest that the intervening Moresby detachment fault was not then manifest as a major topographic feature (Robertson et al., 2001). Geochemical and mineralogical studies of the hemipelagic sediments (Robertson and Sharp, this volume) revealed very high abundances of $\mathrm{Cr}$ and $\mathrm{Ni}$ (and also locally $\mathrm{Cu}$ and $\mathrm{Zn}$ ) sporadically throughout the Pliocene succession at all sites. This implies serpentinized ultramafic rock detritus was able to reach all sites in the basin as fine-grained sediment earlier than the abrupt influx in sandstone detritus after $\sim 3 \mathrm{Ma}$. In addition, relatively high $\mathrm{Al}, \mathrm{K}, \mathrm{Na}$, and minor elements $\mathrm{Rb}, \mathrm{Zr}$, and $\mathrm{Y}$ within lower-middle Pliocene hemipelagic sediments suggest terrigenous-derived sediments had access to the rift basin through low-density turbidity until late Pliocene time (Robertson and Sharp, this volume). Therefore, it is interpreted that all of the sites formed part of single turbiditic basin (or several subbasins) during this time.

The influx of sand-sized serpentinite and metamorphic detritus in the late Pliocene is thought to reflect a major change in the architecture 
of the Woodlark rift basin (Fig. F19). Prior to this time, fine-grained terrigenous-sourced sediments (including detritus from ultramafic rocks) derived from the Papua New Guinea mainland were able to reach the present northern margin of the Woodlark rift, as it did not then exist as a deep rift basin (Robertson and Sharp, this volume). However a discrete pulse of rifting in the late Pliocene resulted in the deepening of the Woodlark rift basin, and terrigenous input to the northern rift margin was cut off (Robertson and Sharp, this volume). The Paleogene Papuan ophiolite belt and the Owen Stanley metamorphics were unroofed as the southern margin of the rift was exhumed (e.g., Moresby Seamount) and, in places, subaerially exposed (e.g., D'Entrecasteaux Islands and onshore Cape Vogel Basin), resulting in new more proximal source of metamorphic, igneous, and ophiolitic detritus (Fig. F20).

The sources of the volcanic detritus in the early Pliocene (see above) continued to supply material throughout the Pliocene (Fig. F20). In addition, vitric fragments present that appear at $<2.5 \mathrm{Ma}$ (Sites 1109 and 1115) are indicative of high-K calc-alkaline volcanic centers, possibly located in the Dawson Strait (e.g., Dobu Seamount) and Moresby Strait, (Lackschewitz et al., 2001; Robertson and Sharp, this volume) (Figs. F19, F20). By this stage, the northern rift margin (Sites 1109 and 1115) was largely isolated from terrigenous sediment input (Fig. F20).

\section{Pleistocene}

Sandstones during this time were deposited in bathyal depths as volcaniclastic turbidites and subordinate air-fall ash (Taylor, Huchon, Klaus, et al., 1999) (Fig. F19). Growth of a carbonate platform on the gently subsiding Trobriand Basin to the northwest (Tjhin, 1976) had the effect of markedly reducing clastic input to the Woodlark Basin during the Pleistocene at Sites 1108, 1109, and 1115 (Robertson et al., 2001).

At Sites 1115 and 1109, colorless vitric volcanic fragments represent the dominant lithic detritus, except for two limited time intervals at Site 1109 where lathwork fragments are predominant (Fig. F19). Sediments of this age recovered from Sites 1108 and 1110-1112 are interpreted as talus deposits, in part (Taylor, Huchon, Klaus, et al., 1999). Clasts recovered from Site 1108 included sandstone, greenschist, dark pelitic schist, and variably altered and deformed dolerite/gabbro. Rare clasts of acid-intermediate porphyry, quartz trachyte, lamprophyre, and sandstone were recovered from Sites 1110-1113. A sandstone clast from Site 1108 is of similar composition (metamorphic and volcanic detritus) to middle Pliocene or younger sandstones of the Woodlark rift basin, which suggests it was eroded from strata of that age within the basin. The abundance of lathwork fragments and detrital clinopyroxene in sandstone clasts from Site 1112 implies they were derived from Pliocene sandstones present in the Woodlark rift basin.

The source of the talus is considered to be due to the continued emergence of Moresby Seamount during the late Pliocene to Pleistocene, as bounded by a major inclined fault scarp (Fig. F20). The talus includes material derived from the Pliocene sedimentary cover of the seamount. Serpentinite was eroded from the seamount as extensional faulting unroofed deeper structural levels and continued unroofing exposed schistose and gneissic rocks of presumably the Owen Stanley metamorphics (Davies, 1980), which structurally underlie the Paleogene ophiolitic rocks on a regional scale. 
Vitric fragments present at Sites 1109 and 1115 are similar in composition to those of late Pliocene age (see above) and are therefore indicative of high-K calc-alkaline volcanic centers possibly located in the Dawson Strait (e.g., Dobu Seamount) and Moresby Strait, (Lackschewitz et al., 2001; Robertson and Sharp, this volume) (Fig. F20). Other volcanic detritus of this age might have been sourced from Woodlark Island, the eastern Papua Peninsula, and/or the D'Entrecasteaux Islands (Fig. F20).

\section{CONCLUSIONS}

1. Sandstone detritus within the middle Miocene Trobriand forearc basin was derived predominantly from pyroxene basalts and from less-abundant silicic volcanics. Calc-alkaline volcanics related to the Trobriand Arc are thought to be the source for this detritus. However calc-alkaline volcanoes located within the inferred forearc (e.g., Woodlark Island) might also have provided a source. The presence of silicic and alkalic volcanic debris in rocks of this age further suggests that the contemporary Trobriand arc had a complex volcanic history (Figs. F19, F20).

2. With the onset of rifting in the late Miocene, sandstone and conglomerate deposited in the Woodlark rift basin prograded generally northward. They progressively covered and were sourced from the exposed Trobriand outerarc/forearc, which included Paleogene ophiolitic rocks. Derivation from the hinterland of Papua New Guinea, including the Paleogene Papuan ophiolite belt is unlikely, as ophiolite rocks other than metadolerite are absent from the detritus of the sandstones (Figs. F19, F20).

3. Upper Miocene-Pleistocene sandstone deposited during continuing extension and subsidence of Woodlark Basin indicates a change to more explosive silicic volcanism, although sporadic basaltic/doleritic detritus in rocks of this age indicates mafic volcanics continued supplying the basin. Assuming sediment pathways were similar to today (from the northwest), the probable source of ash and volcaniclastic turbidites were the Amphlett Islands, Moresby Strait, Dawson Strait (e.g., Dobu Seamount), and surrounding areas where Pliocene-Pleistocene volcanic rocks occur. Additional sources of volcanics could be the D'Entrecasteaux Islands, active Trobriand Arc volcanoes on the northern rift margin (i.e., the Luscany Islands, Trobriand Island, Woodlark Island, and Egum Atoll), the eastern Papua Peninsula, and sediment reworked from the Cape Vogel Basin to the northwest (Figs. F19, F20).

4. Complementary geochemical studies (Robertson and Sharp, this volume) revealed sporadic absolute abundances of trace metals $\mathrm{Cr}$ and $\mathrm{Ni}$ and, locally, $\mathrm{Cu}$ and $\mathrm{Zn}$ in Pliocene hemipelagic sediments and relatively high $\mathrm{Al}, \mathrm{K}, \mathrm{Na}$, and minor elements $\mathrm{Rb}, \mathrm{Zr}$, and $\mathrm{Y}$ within lower-middle Pliocene hemipelagic sediments. These are interpreted to indicate that terrigenous and ultramafic derived sediments had access through fine-grained sediments to a single turbiditic Woodlark rift basin (or several subbasins) until late Pliocene time (Robertson and Sharp, this volume) (Figs. F19, F20).

5. The influx of sand-sized serpentinite and metamorphic detritus in the late Pliocene $(\sim 3 \mathrm{Ma})$ is thought to reflect a major change 
in the architecture of the Woodlark rift basin. A discrete pulse of rifting in the late Pliocene resulted in the deepening of the Woodlark rift basin, and terrigenous input to the northern rift margin was cut off. The Paleogene Papuan ophiolite belt and the Owen Stanley metamorphics were unroofed as the southern margin of the rift was exhumed (e.g., Moresby Seamount) and, in places, subaerially exposed (e.g., D'Entrecasteaux Islands and onshore Cape Vogel Basin), resulting in new and more proximal source of metamorphic, igneous, and ophiolitic detritus. Continued emergence of the Moresby Seamount during the late Pliocene-early Pleistocene bounded by a major inclined fault scarp yielded talus deposits of similar composition to the above sandstones (Figs. F19, F20).

6. Growth of a carbonate platform on the gently subsiding Trobriand Basin to the northwest (Tjhin, 1976) markedly reduces the clastic input the Woodlark rift basin throughout the Pleistocene. Silicic vitric fragments become the dominant type of detritus deposited at Sites 1109 and 1118 during this time. These glasses are indicative of high-K calc-alkaline volcanic centers, possibly located in the Dawson Strait, Moresby Strait, or Dobu Seamount area (Lackschewitz et al., 2001; Robertson and Sharp, this volume) (Figs. F19, F20).

\section{ACKNOWLEDGMENTS}

This research used samples provided by the Ocean Drilling Program (ODP). ODP is sponsored by the U.S. National Science Foundation (NFSF) and participating countries under management of Joint Oceanographic Institutions (JOI), Inc. The first author thanks Professor Evan Leitch and Associate Professor Greg Skilbeck for advice on the petrological work, Dr. Graziella Caprarelli for confirming mineral identifications by the use of an electron microprobe, and Dr. Tony Allan for advice on carbonate petrology. Freeman Ryan Design is thanked for assistance with the figures and plates. This postcruise work was supported by a grant from the Australian ODP Secretariat. The second author acknowledges the financial support of the UK National Environmental Research Council during the cruise to postcruise work. Constructive reviews were received from Dr. Chris Fergusson and Dr. Moyra Wilson. 


\section{REFERENCES}

Ashley, P.M., and Flood, R.H., 1981. Low-K tholeiites and high-K igneous rocks from Woodlark Island, Papua New Guinea. J. Geol. Soc. Aust., 28:227-240.

Binns, R.A., Scott, S.D., and PACLARK Participants, 1987. Western Woodlark Basin: potential analogue setting for volcanogenic massive sulphite deposits. Proc. Pac. Rim Cong., 87:531-535.

Benes, V., Scott, S.D., and Binns, R.A., 1994. Tectonics of rift propagation into a continental margin: western Woodlark Basin, Papua New Guinea. J. Geophys. Res., 99:4439-4455.

Berggren, W.A., Kent, D.V., Swisher, C.C., III, and Aubry, M.P., 1995. A revised Cenozoic geochronology and chronostratigraphy. In Berggren, W.A., Kent, D.V., Aubry, M.P. and Hardenbol, J., (Eds.), Geochronology, Time Scales and Global Stratigraphic Correlation. Spec. Publ._Soc. Econ. Paleontol. Mineral., 54:129-212.

Davies, H.L., 1980. Folded thrust and associated metamorphics in the Suckling-Dayman Massif, Papua New Guinea. Am. J. Sci., 280-A:171-191.

Davies, H.L., and Jaques., A.L., 1984. Emplacement of ophiolite in Papua New Guinea. In Gass, I.G., Lippar, S.J., and Shelton, A.W. (Eds.), Ophiolites and Oceanic Lithosphere. Spec. Publ.-Geol. Soc., London, 13:341-350.

Davies, H.L., Honza, E., Tiffin, D.L., Lock, J., Okuda, Y., Keene, J.B., Murakami, F., and Kisimoto, K., 1987. Regional setting and structure of the western Solomon Sea. Geo-Mar. Lett., 7:153-160.

Dickinson, W.R., 1970. Interpreting detrital modes of greywacke and arkose. J. Sediment. Petrol., 40:695-707.

Dickinson,W.R., Beard, L.S., Brackenridge, G.R., Erjavec, J.L., Ferguson, R.C., Inman, K.F., Knepp, R.A., Lindberg, F.A., and Ryberg, P.T., 1983. Provenance of North American Phanerozoic sandstones in relation to tectonic setting. Geol. Soc. Am. Bull., 94:222-235.

Dott, R.L., 1964. Wacke, greywacke and matrix; what approach to immature sandstone classification? J. Sediment. Petrol., 34:625-632.

Harris, C.S., Varol, O., and Mortimer, C.P., 1985. Biostratigraphy of the Goodenough1 and Nubiam-1 wells from the Cape Vogel Basin and the L'etoile-1 well from the Bougainville Basin. Robertson Research Report, 1486.

Honza, E., Davies, H.L., Keene, J.B., and Tiffin, D.L., 1987. Plate boundaries and evolution of the Solomon Sea region. Geo-Mar. Lett., 7:161-168.

Ingersoll, R.V., Bullard, T.F., Ford, R.L., Grimm, J.P., Pickle, J.D. and Sares, S.W., 1984. The effect of grain size on detrital modes: a test of the Gazzi-Dickinson pointcounting method. J. Sediment. Petrol., 54:103-116.

Lackschewitz, B.D., Bogaard, P.V.D., and Mertz, D.F., 2001. ${ }^{40} \mathrm{Ar}-{ }^{39} \mathrm{Ar}$ ages of MiocenePleistocene fallout tephra layers and volcaniclastic deposits in the sedimentary succession of the western Woodlark Basin, Papua New Guinea. In Wilson, R.C.L., Whitmarsh, R.B., Taylor, B., and Froitzheim, N. (Eds.), Non Volcanic Rifting of Continental Margins: Evidence from Land and Sea. Spec. Publ.-Geol. Soc. London, 187:373-388.

Lock, J., Davies, H.L., Tiffin, D.L., Murakami, F., and Kisomoto, K., 1987. The Trobriand subduction system in the western Solomon Sea. Geo-Mar. Lett., 7:129-134.

Resig, J.M., Frost, G.M., Ishikawa, N., and Perembo, R.C.B., in press. Micropaleontologic and paleomagnetic approaches to stratigraphic anomalies in rift basins: ODP Site 1109, Woodlark Basin. In Wilson, R.C.L., Whitmarsh, R.B., Taylor, B and Froitzheim, N. (Eds.), Non-Volcanic Rifting of Continental Margins: Evidence from Land and Sea. Spec. Publ.-Geol. Soc. London.

Robertson, A.H.F., Awadallah, S.A.M., Gerbaudo, S., Lackschewitz, K.S., Monteleone, B.D., Sharp, T.R., and the ODP Leg 180 Shipboard Scientific Party, 2001. Evolution of the Miocene-Recent Woodlark rift basin, SW Pacific, inferred from sediments drilled during Ocean Drilling Program Leg 180. In Wilson, R.C.L., Froitzheim, N., 
Taylor, B., and Whitmarsh R.B. (Eds.), Non-Volcanic Rifting of Continental Margins: A Comparison of Evidence from Land and Sea. Spec. Publ.-Geol. Soc. London, 187:335-372.

Smith, I.E.M., 1982. Volcanic evolution in eastern Papua. Tectonophysics, 87:315-333.

Smith, I.E.M., and Milsom, J.S., 1984. Late Cenozoic volcanism and extension in eastern Papua. In Kokelaar, B.P., and Howells, M.F. (Eds.), Marginal Basin Geology. Spec. Publ.-Geol. Soc. London, 16:163-171.

Taylor, B., Goodliffe, A., and Martinez, F., 1999. How continents break up: insights from Papua New Guinea. J. Geophys. Res., 104:7497-7512.

Taylor, B., Goodliffe, A., Martinez, F., and Hey, R., 1995. Continental rifting and initial seafloor spreading in the Woodlark Basin. Nature, 374:534-537.

Taylor, B., Huchon, P., Klaus, A. et al., 1999. Proc. ODP, Init. Repts., 180 [CD-ROM]. Available from: Ocean Drilling Program, College Station, TX 77843-9547, U.S.A.

Tjhin, K.T., 1976. Trobriand Basin Exploration, Papua New Guinea. APEA J., 16:8190.

Weissel, J.K., Taylor, B., and Karner, G.D., 1982. The opening of the Woodlark Basin, subduction of the Woodlark spreading system and the evolution of northern Melanesia since mid-Pliocene time. Tectonophysics, 87:253-277.

Zuffa, G.G. 1980. Hybrid arenites: their composition and classification. J. Sediment. Petrol., 50:21-29. 
Figure F1. Regional tectonic setting of the Woodlark Basin adjacent to the Papuan Peninsula; inset: wider regional location. G-1 = Goodenough1 well, N-1 = Nubiam-1 well, CV = Cape Vogel Basin (onshore), E = Egum Island, F = Fergusson Island, G = Goodenough Island, MB = Milne Bay, MS = Moresby Seamount, N = Normanby Island, $\mathrm{Tr}=$ Trobriand Island, $\mathrm{W}=$ Woodlark Island (from Robertson et al., 2001, modified from Taylor, Huchon, Klaus et al., 1999).

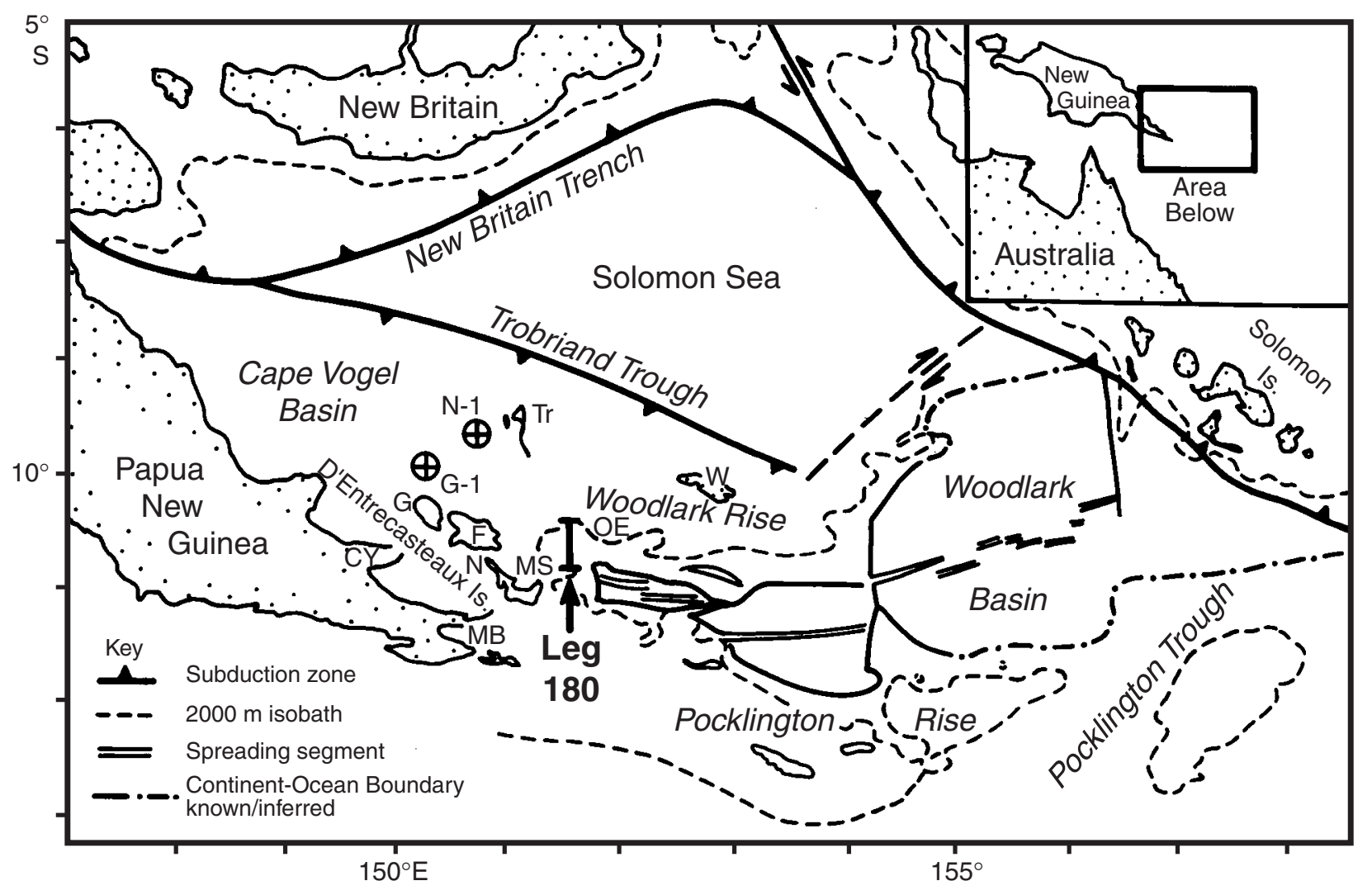


T. SHARP AND A. ROBERTSON

VOLCANIC SANDS AND SANDSTONES

Figure F2. Locations of sites drilled during Leg 180 (modified from Leg 180 Initial Reports, Taylor, Huchon, Klaus, et al., 1999).

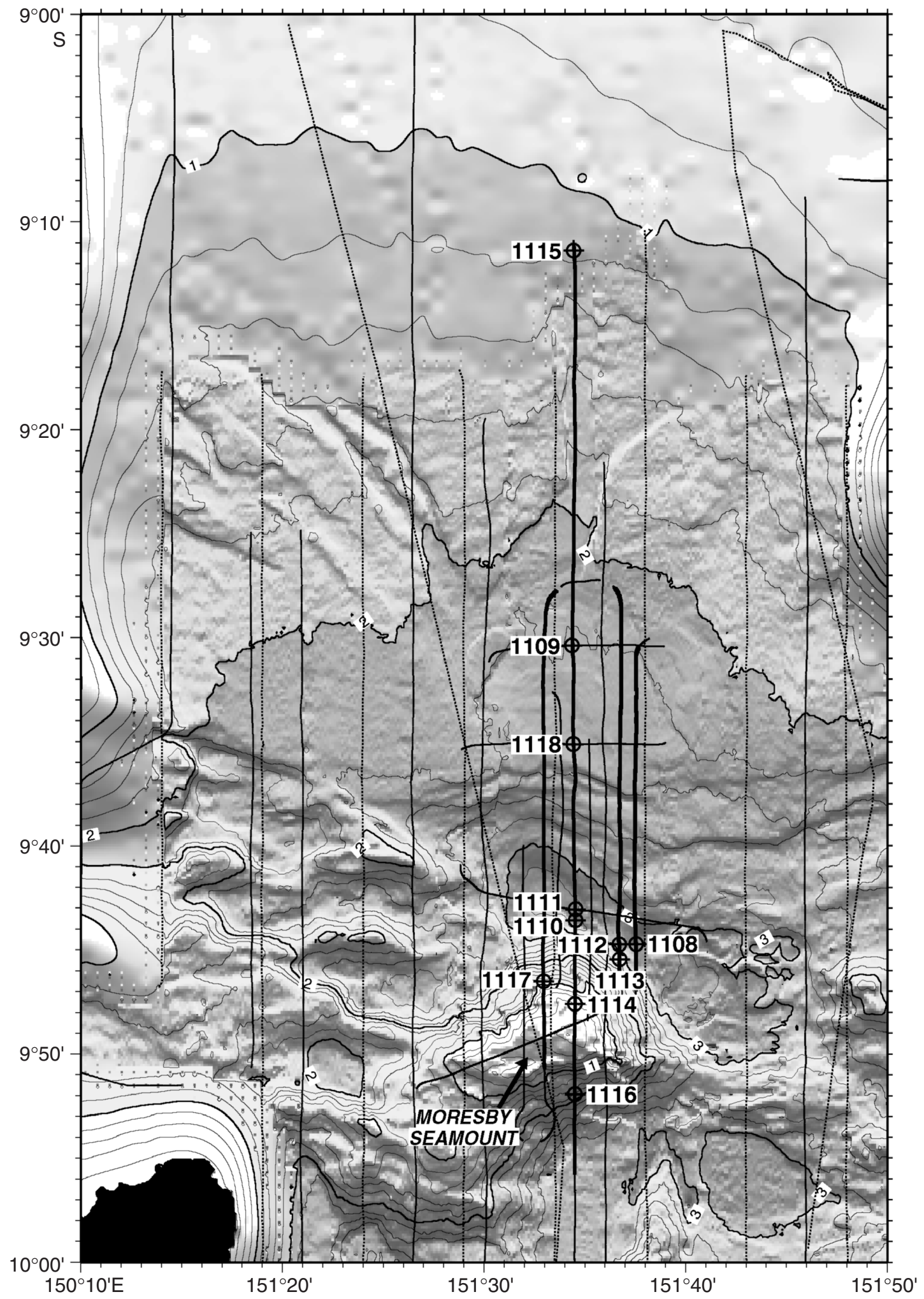


T. SHARP AND A. ROBERTSON

VOLCANIC SANDS AND SANDSTONES

Figure F3. Line diagrams showing interpretations of north-south seismic profiles along which the Leg 180 sites were drilled. A. Westerly profile. B. Easterly profile. See Figure F2, p. 26, for locations (from Robertson et al., 2001, based on seismic reflection profiles in Taylor et al., 1995).

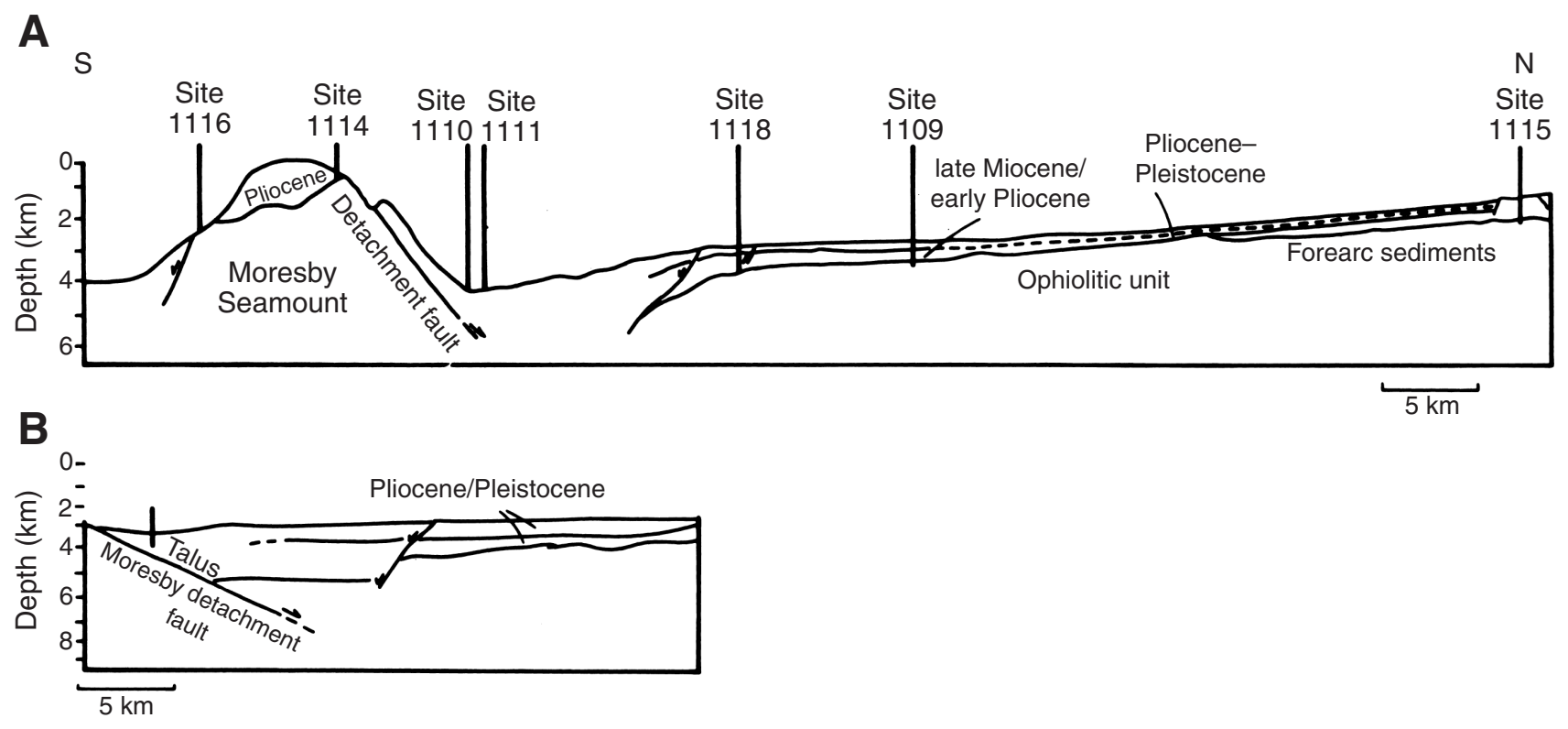


Figure F4. Age-depth chart for the Leg 180 sites, including a summary of inferred sedimentation rates and depths (below) complied by Leg 180 shipboard biostratigraphers and magnetostratigraphers (modified after Taylor, Huchon, Klaus, et al., 1999). Sedimentation curves: solid line $=$ Site 1115 , dashed line $=$ Site 1109 , dotted line $=$ Site 1118 , solid line $($ upper right $)=$ Site 1108 , dashed line $($ upper right $)=$ Site 1114 , dotted line (upper right $)=$ Site 1116. Squares $=$ nannofossil datum events, circles = planktonic foraminifer datum events, triangles = magnetic chron and subchron boundaries, star = lithostratigraphic correlation, shaded to differentiate sites. Symbols with arrows = actual datum point can be above or below and older or younger than indicated by the symbols, wavy lines $=$ unconformities. Shown below are average sedimentation rates in meters per million years, calculated for intervals separated by vertical lines, and palaeobathymetry, based on benthic foraminifers, at Sites 1115, 1109, and 1118. Broken lines = uncertainty in the placement of paleodepth boundaries.

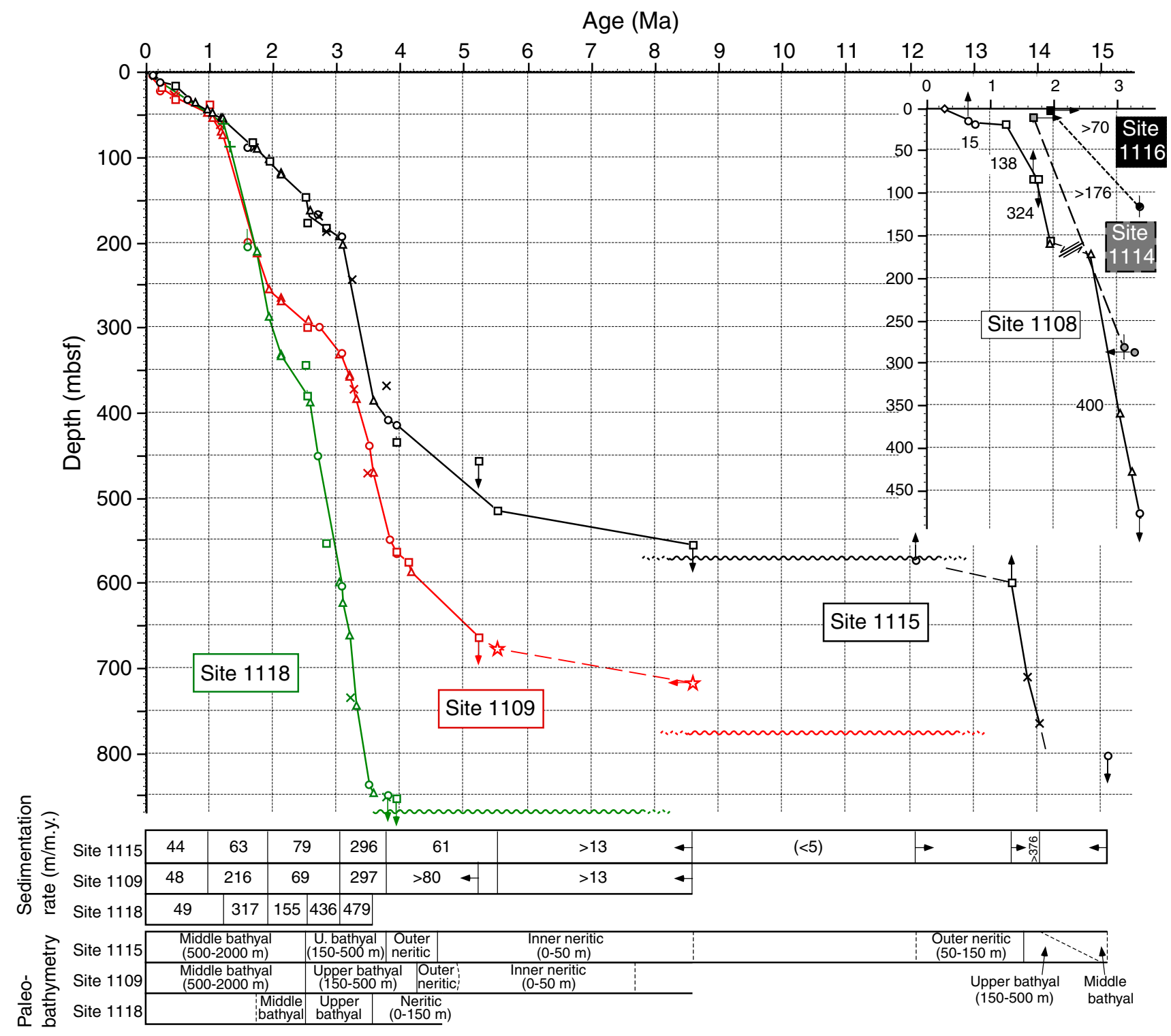


Figure F5. Summary of the sedimentary succession drilled on northern margin sites of the Woodlark rift basin. See Figure F2, p. 26, for locations (from Robertson et al., 2001, modified from Taylor, Huchon, Klaus et al., 1999).

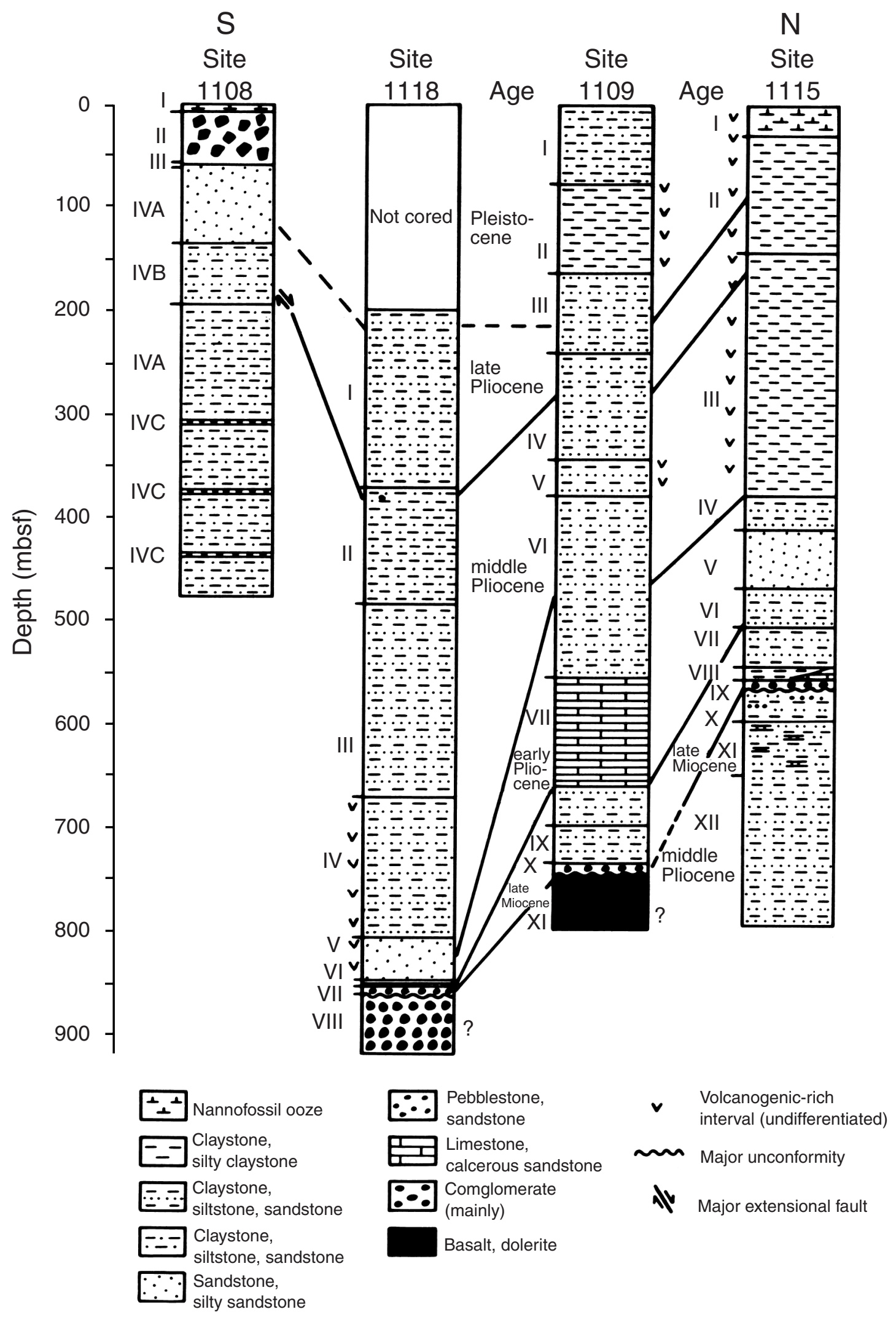


Figure F6. Downhole variation diagrams for Site 1115 (see Table T1, p. 46, for further information). Total detrital cbnte = carbonate skeletal (e.g., foraminifers, shell fragments, red algae, bryozoans, etc.) + carbonate aggre (detital carbonate aggregates), Carb = carbonaceous fragments (plant debris), $\mathrm{Q}=$ total quartzose grains, $\mathrm{F}=$ total feldspar grains, $\mathrm{M}=$ matrix, $\mathrm{C}=$ cement, $\mathrm{Lv}=$ total volcanic grains, $\mathrm{Lm}=$ total metamorphic lithic grains, Biot $=$ biotite, Musc $=$ muscovite, Cpyx $=$ clinopyroxene, Hnbld $=$ hornblende, Lvf = volcanic lithic grains with felsitic texture, Lvv clgl = colorless vitric volcanic lithic grains, Lvv brgl = brown vitric volcanic lithic grains, Lvl = volcanic lithic grains with lathwork texture, Lvm hyal $\mathrm{brgl}=$ volcanic lithic grains with microlites set in a glassy brown groundmass, Lvm hyal clgl = volcanic lithic grains with microlites set in a glassy brown groundmass, Lvm pilo = volcanic lithic grains with interwoven microlites .

\section{Site 1115}

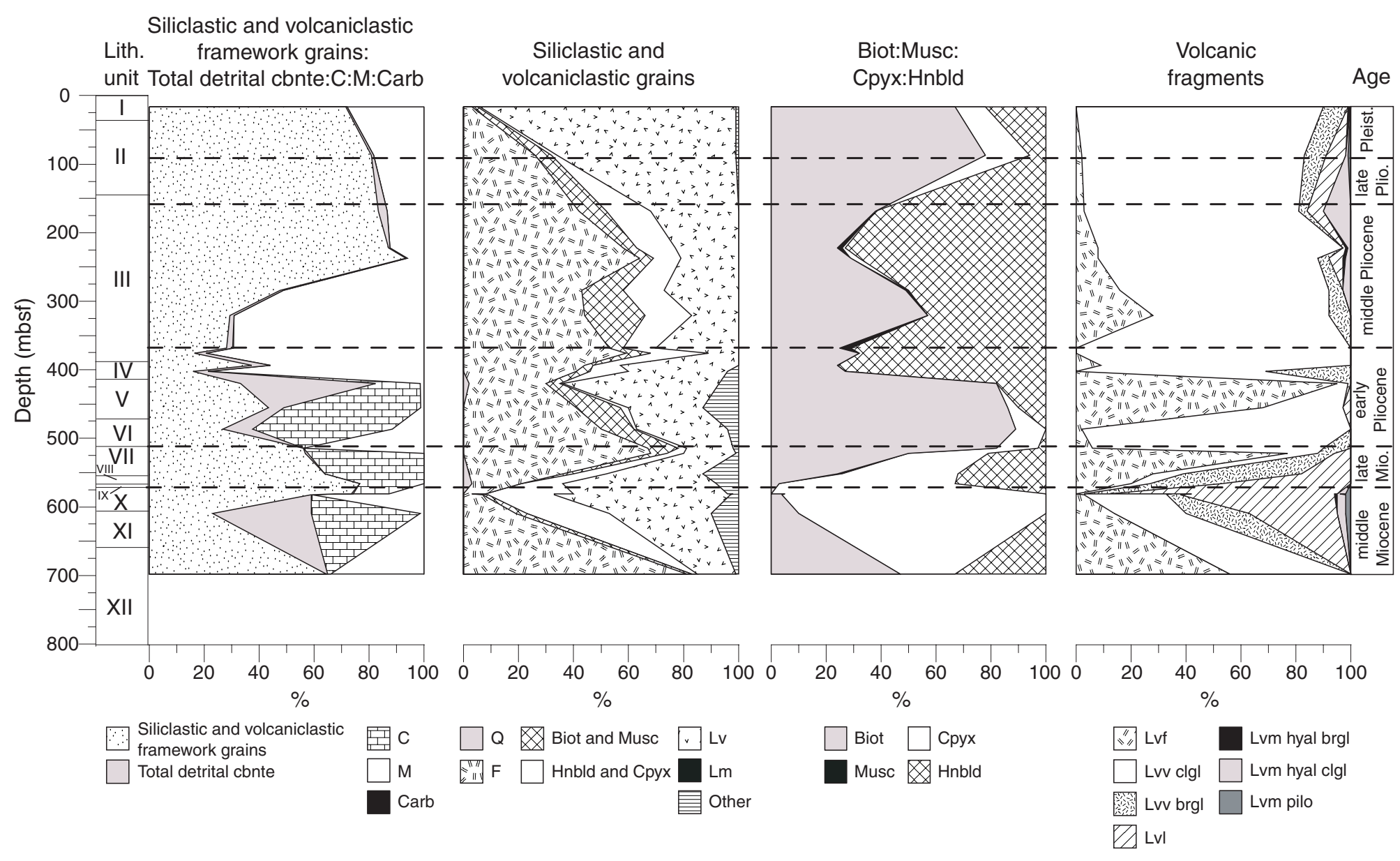


Figure F7. Downhole variation diagrams for Site 1109 (see Table T1, p. 46, for further information). Total detrital cbnte = carbonate skeletal (e.g., foraminifers, shell fragments, red algae, bryozoans, etc.) + carbonate aggre (detital carbonate aggregates), Carb = carbonaceous fragments (plant debris), $\mathrm{Q}=$ total quartzose grains, $\mathrm{F}=$ total feldspar grains, $\mathrm{M}=$ matrix, $\mathrm{C}=$ cement, $\mathrm{Lv}=$ total volcanic grains, $\mathrm{Lm}=$ total metamorphic lithic grains, Biot $=$ biotite, Musc $=$ muscovite, Cpyx $=$ clinopyroxene, Hnbld $=$ hornblende, Lvf = volcanic lithic grains with felsitic texture, Lvv clgl = colorless vitric volcanic lithic grains, Lvv brgl = brown vitric volcanic lithic grains, Lvl = volcanic lithic grains with lathwork texture, Lvm hyal $\mathrm{brgl}=$ volcanic lithic grains with microlites set in a glassy brown groundmass, Lvm hyal clgl = volcanic lithic grains with microlites set in a glassy brown groundmass, Lvm pilo = volcanic lithic grains with interwoven microlites .

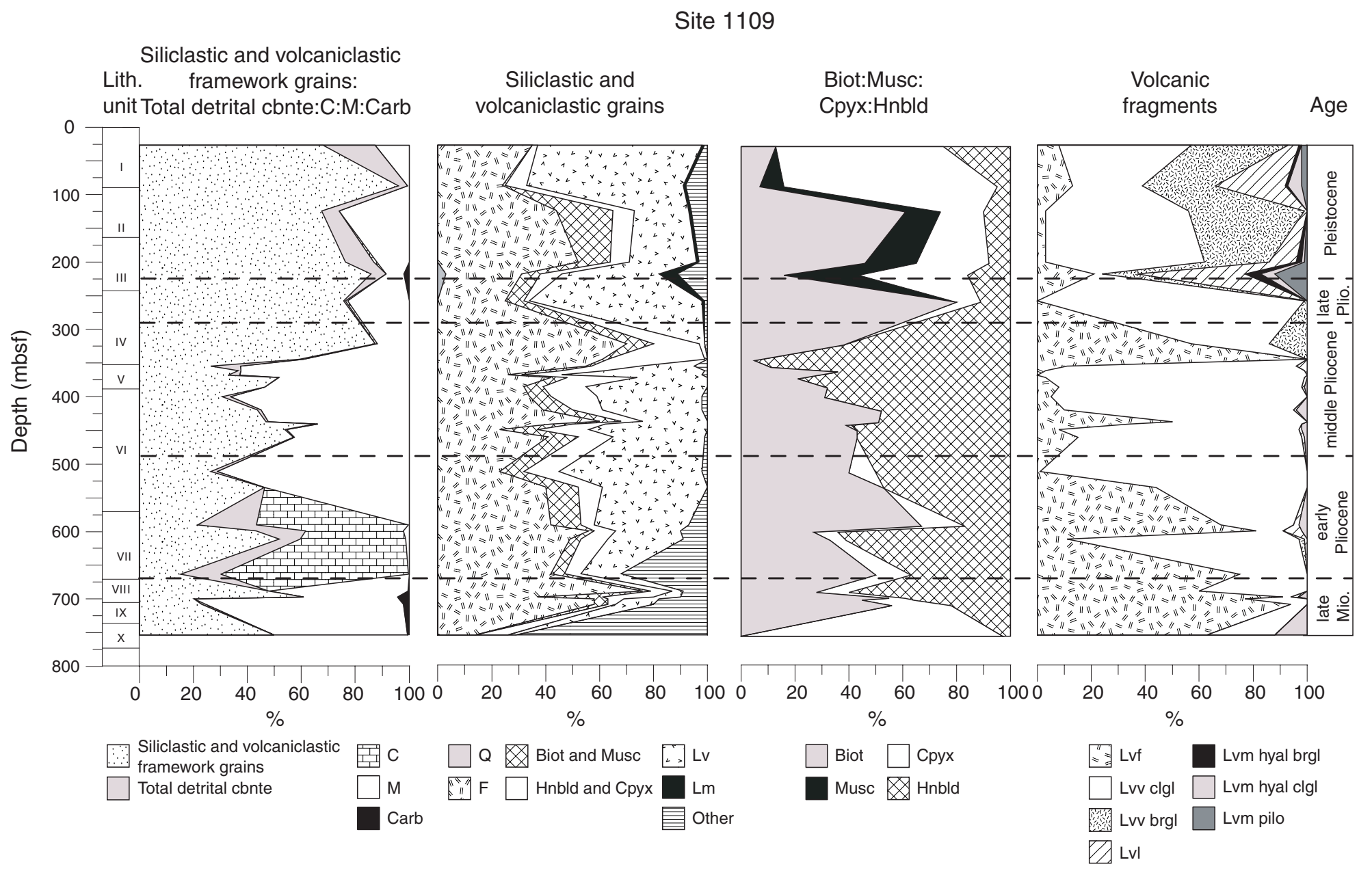


Figure F8. Downhole variation diagrams for Site 1118 (see Table T1, p. 46, for further information). Total detrital cbnte = carbonate skeletal (e.g., foraminifers, shell fragments, red algae, bryozoans, etc.) + carbonate aggre (detital carbonate aggregates), Carb = carbonaceous fragments (plant debris), $\mathrm{Q}=$ total quartzose grains, $\mathrm{F}=$ total feldspar grains, $\mathrm{M}=$ matrix, $\mathrm{C}=$ cement, $\mathrm{Lv}=$ total volcanic grains, $\mathrm{Lm}=$ total metamorphic lithic grains, Biot $=$ biotite, Musc $=$ muscovite, Cpyx $=$ clinopyroxene, Hnbld $=$ hornblende, $\mathrm{Lvf}=$ volcanic lithic grains with felsitic texture, $\mathrm{Lvv}$ clgl $=$ colorless vitric volcanic lithic grains, Lvv brgl = brown vitric volcanic lithic grains, Lvl = volcanic lithic grains with lathwork texture, Lvm hyal brgl = volcanic lithic grains with microlites set in a glassy brown groundmass, Lvm hyal clgl = volcanic lithic grains with microlites set in a glassy brown groundmass, Lvm pilo = volcanic lithic grains with interwoven microlites.

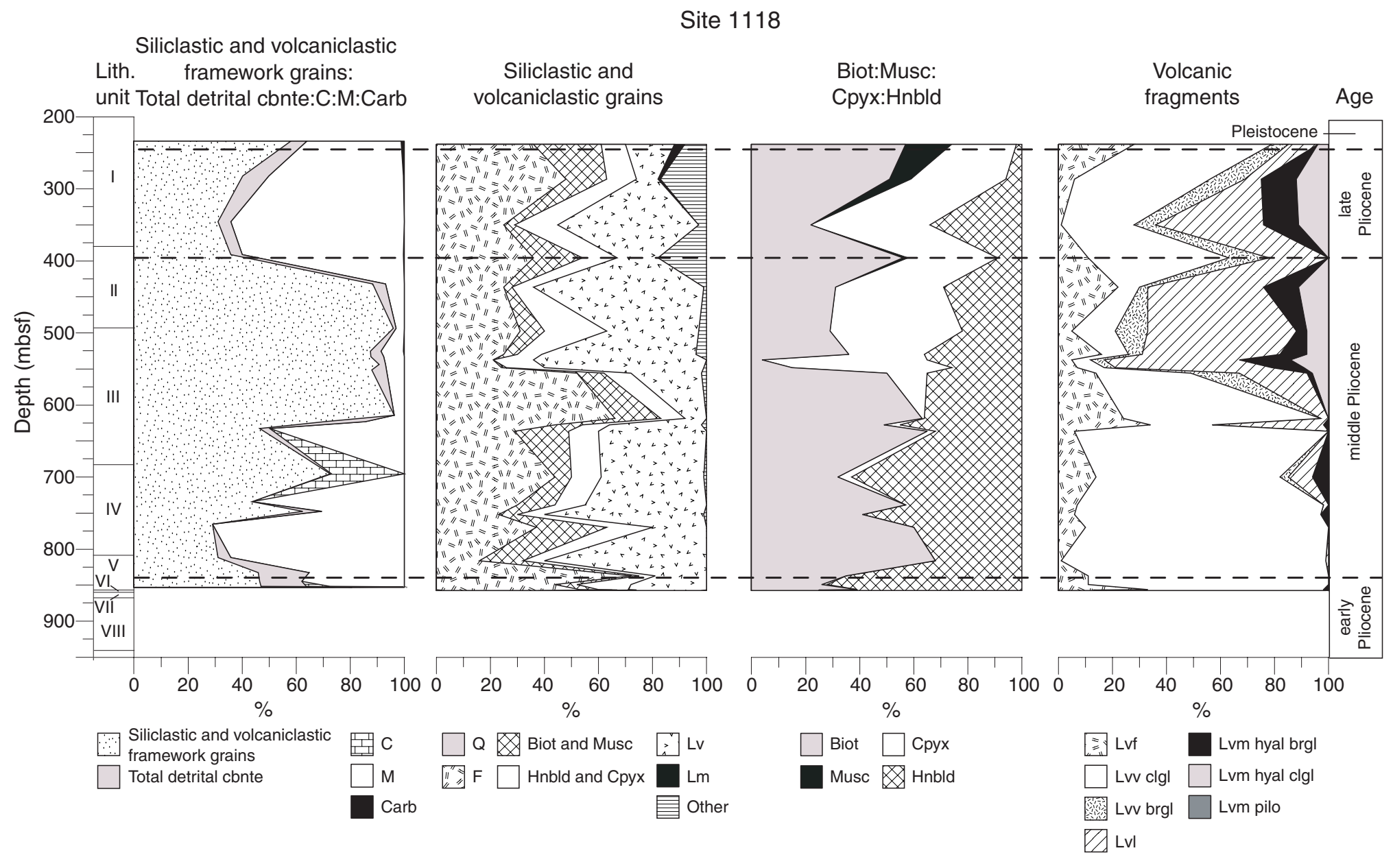


Figure F9. Downhole variation diagrams for Site 1108 (see Table T1, p. 46, for further information). Total detrital cbnte = carbonate skeletal (e.g., foraminifers, shell fragments, red algae, bryozoans, etc.) + carbonate aggre (detital carbonate aggregates), Carb = carbonaceous fragments (plant debris), $\mathrm{Q}=$ total quartzose grains, $\mathrm{F}=$ total feldspar grains, $\mathrm{M}=$ matrix, $\mathrm{C}=$ cement, $\mathrm{Lv}=$ total volcanic grains, $\mathrm{Lm}=$ total metamorphic lithic grains, Biot $=$ biotite, Musc $=$ muscovite, Cpyx $=$ clinopyroxene, Hnbld $=$ hornblende, Lvf = volcanic lithic grains with felsitic texture, Lvv clgl = colorless vitric volcanic lithic grains, Lvv brgl = brown vitric volcanic lithic grains, Lvl = volcanic lithic grains with lathwork texture, Lvm hyal $\mathrm{brgl}=$ volcanic lithic grains with microlites set in a glassy brown groundmass, Lvm hyal clgl = volcanic lithic grains with microlites set in a glassy brown groundmass, Lvm pilo = volcanic lithic grains with interwoven microlites

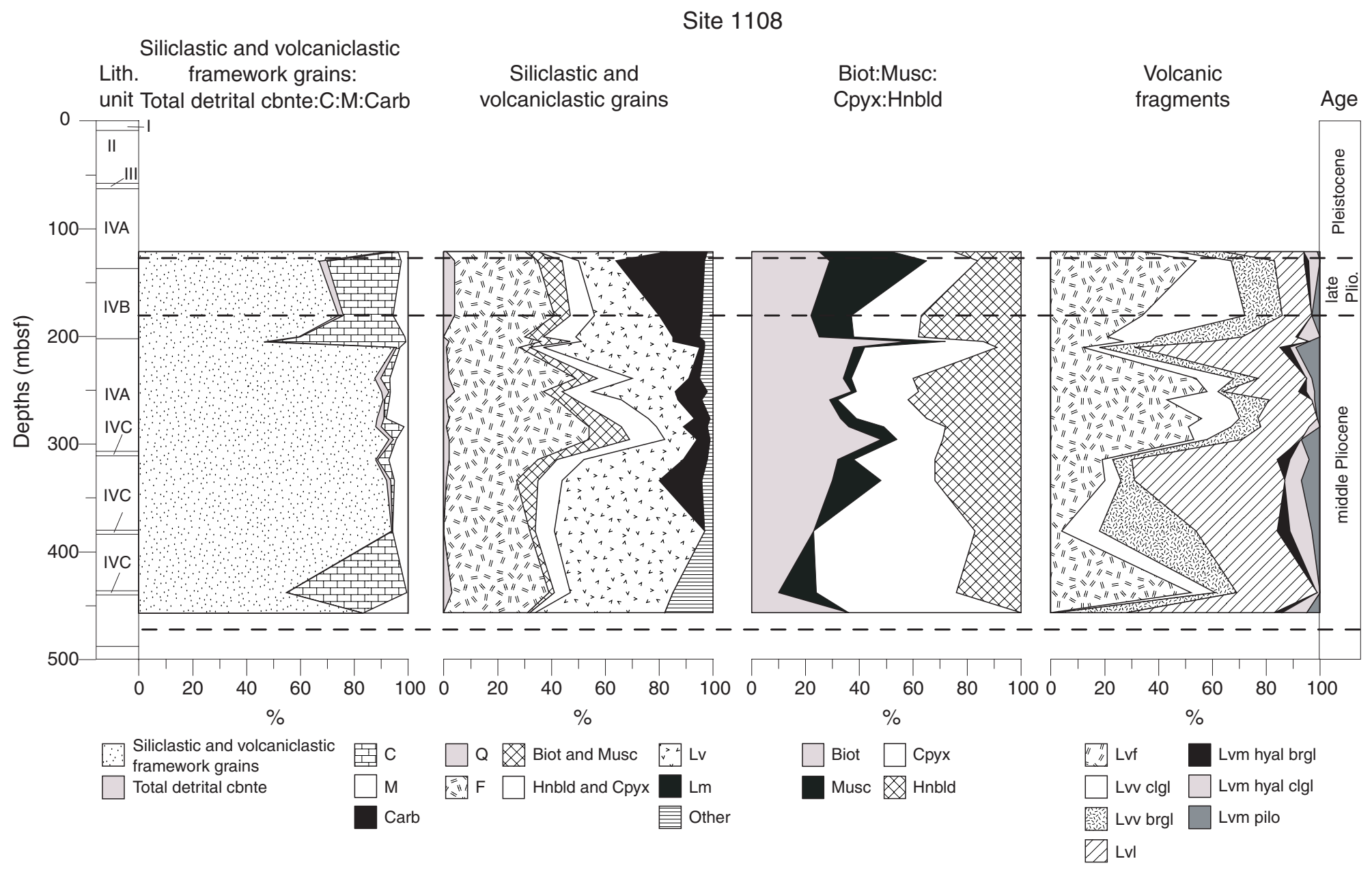


Figure F10. Comparison of downhole variation diagrams of the ratios of siliciclastic and volcaniclastic framework grains: total detrital cbnte: carbonaceous detritus: cement: matrix, for all the northern sites (see Table T1, p. 46, for further information). Total detrital cbnte $=$ carbonate skeletal

(e.g., foraminifers, shell fragments, red algae, bryozoans, etc.) + carbonate aggre (detital carbonate aggregates), Carb $=$ carbonaceous fragments (plant debris), $\mathrm{M}=$ matrix, $\mathrm{C}=$ cement.

Siliclastic and volcaniclastic framework grains:Total detrital cbnte:C:M:Carb

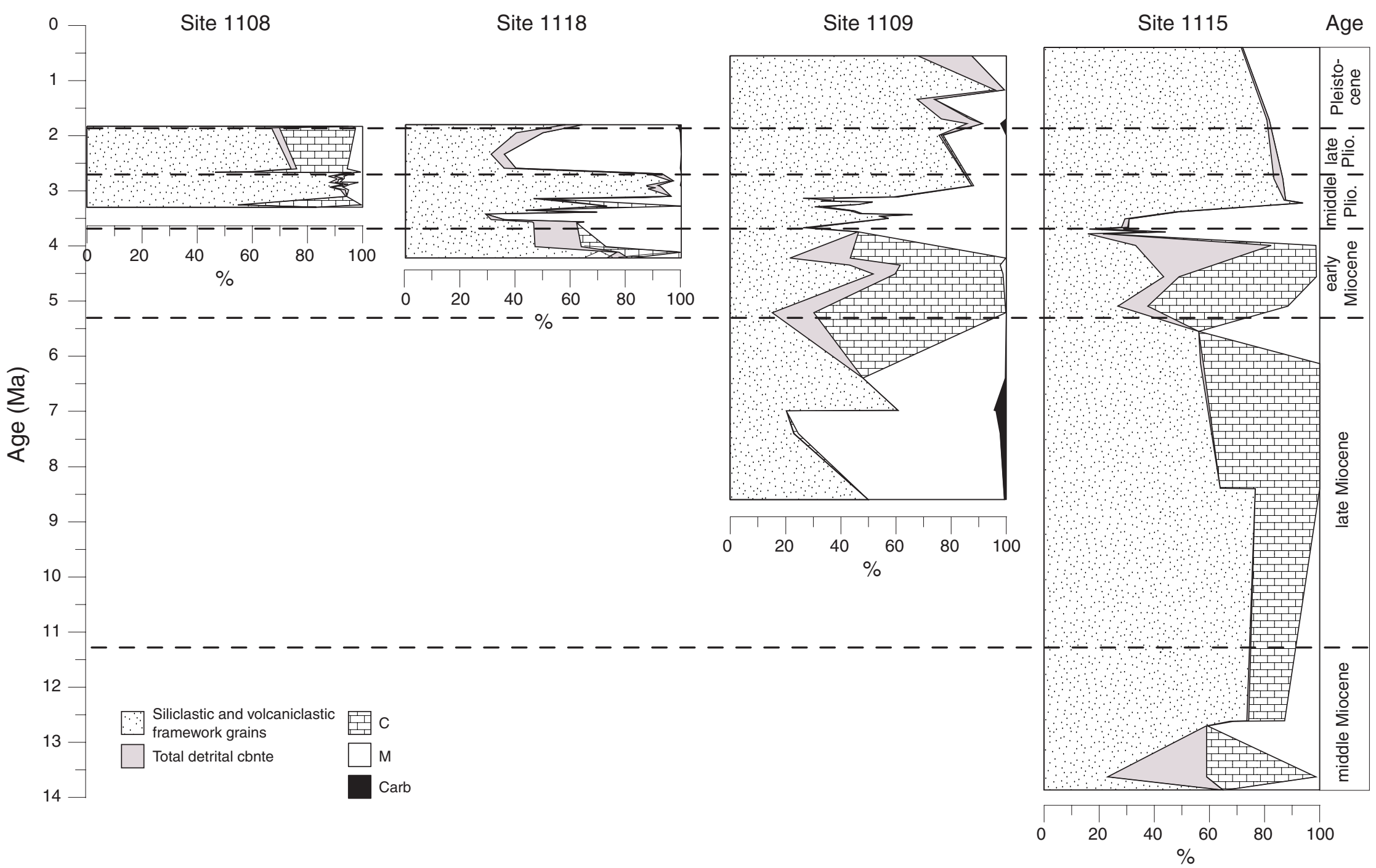


Figure F11. Comparison of downhole variation of the ratios of siliciclastic and volcaniclastic grains for all the northern sites (see Table T1, p. 46, for further information). $\mathrm{Q}=$ total quartzose grains, $\mathrm{F}=$ total feldspar grains, $\mathrm{Lv}=$ total volcanic grains, $\mathrm{Lm}=$ total metamorphic lithic grains, Biot = biotite, Musc $=$ muscovite, Cpyx = clinopyroxene, Hnbld = hornblende, Other $=$ actinolite, epidote, sphene, zircon, olivine, opaque minerals (e.g., pyrite, magnetite, and chromite), limonite, prehnite, and pumpellyite.

Siliclastic and volcaniclastic grains
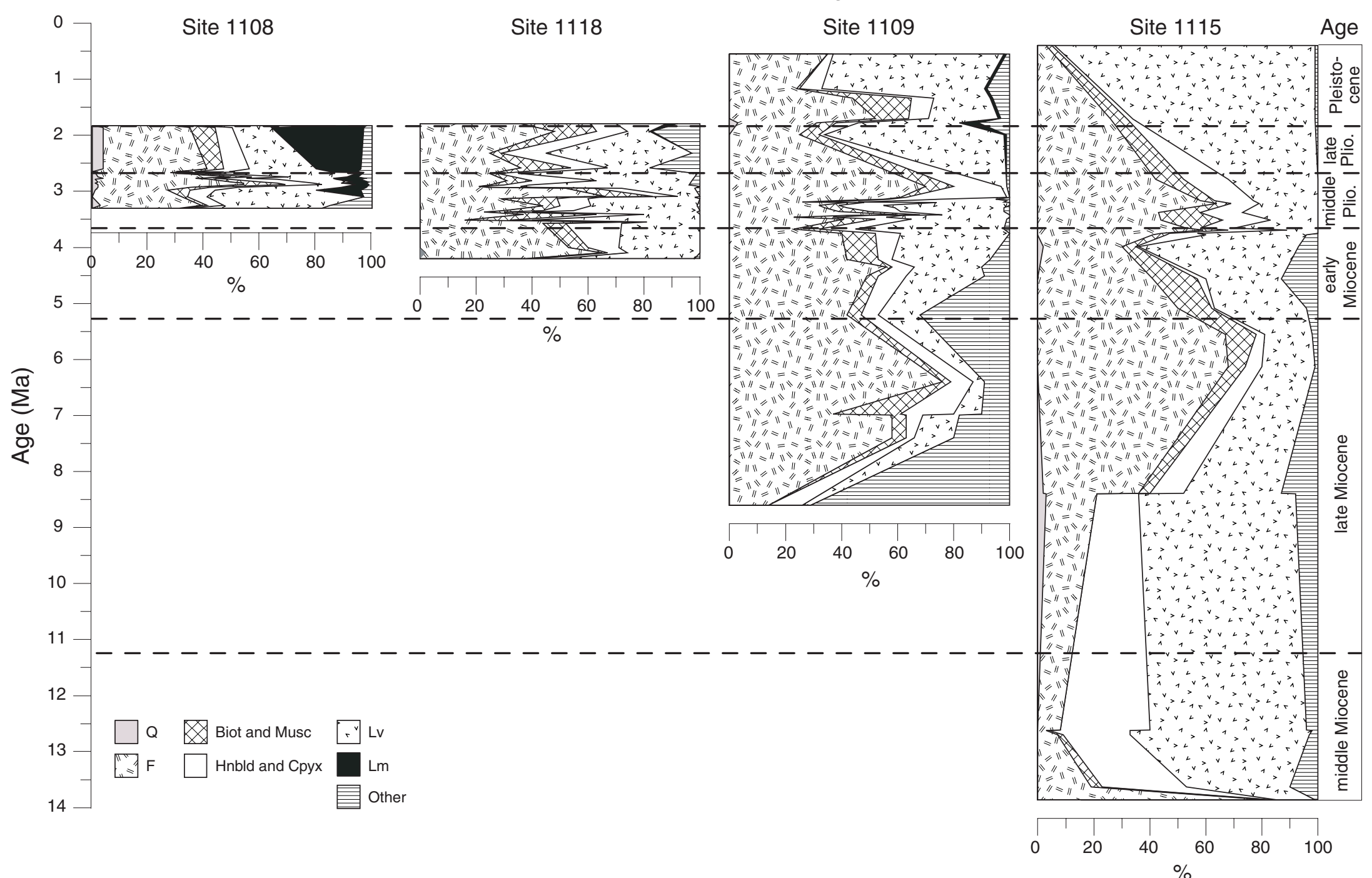
Figure F12. Comparison of downhole variation of the ratios of biotite:muscovite:clinopyroxene:amphibole for all the northern sites (see Table T1, p. 46, for further information). Biot = biotite, Musc = muscovite, Cpyx = clinopyroxene, Hnbld = hornblende.

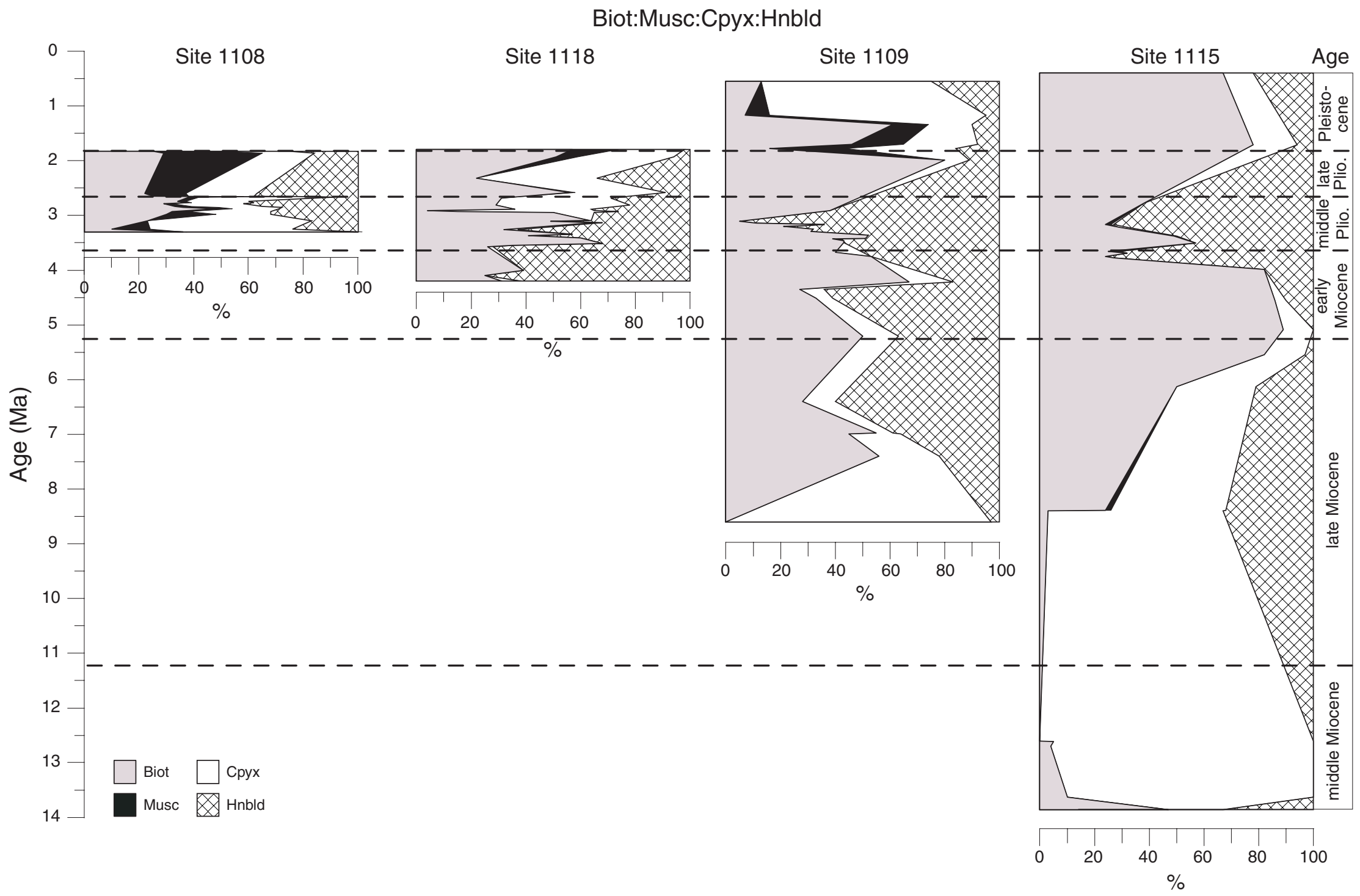


Figure F13. Comparison of downhole variation of the ratios of volcanic rock fragments for all the northern sites (see Table T1, p. 46, for further information). $\mathrm{Lvf}=$ volcanic lithic grains with felsitic texture, $\mathrm{Lvv}$ clgl = colorless vitric volcanic lithic grains, Lvv brgl = brown vitric volcanic lithic grains, Lvl= volcanic lithic grains with lathwork texture, Lvm hyal brgl = volcanic lithic grains with microlites set in a glassy brown groundmass, Lvm hyal clgl = volcanic lithic grains with microlites set in a glassy brown groundmass, Lvml pilo = volcanic lithic grains with interwoven microlites.

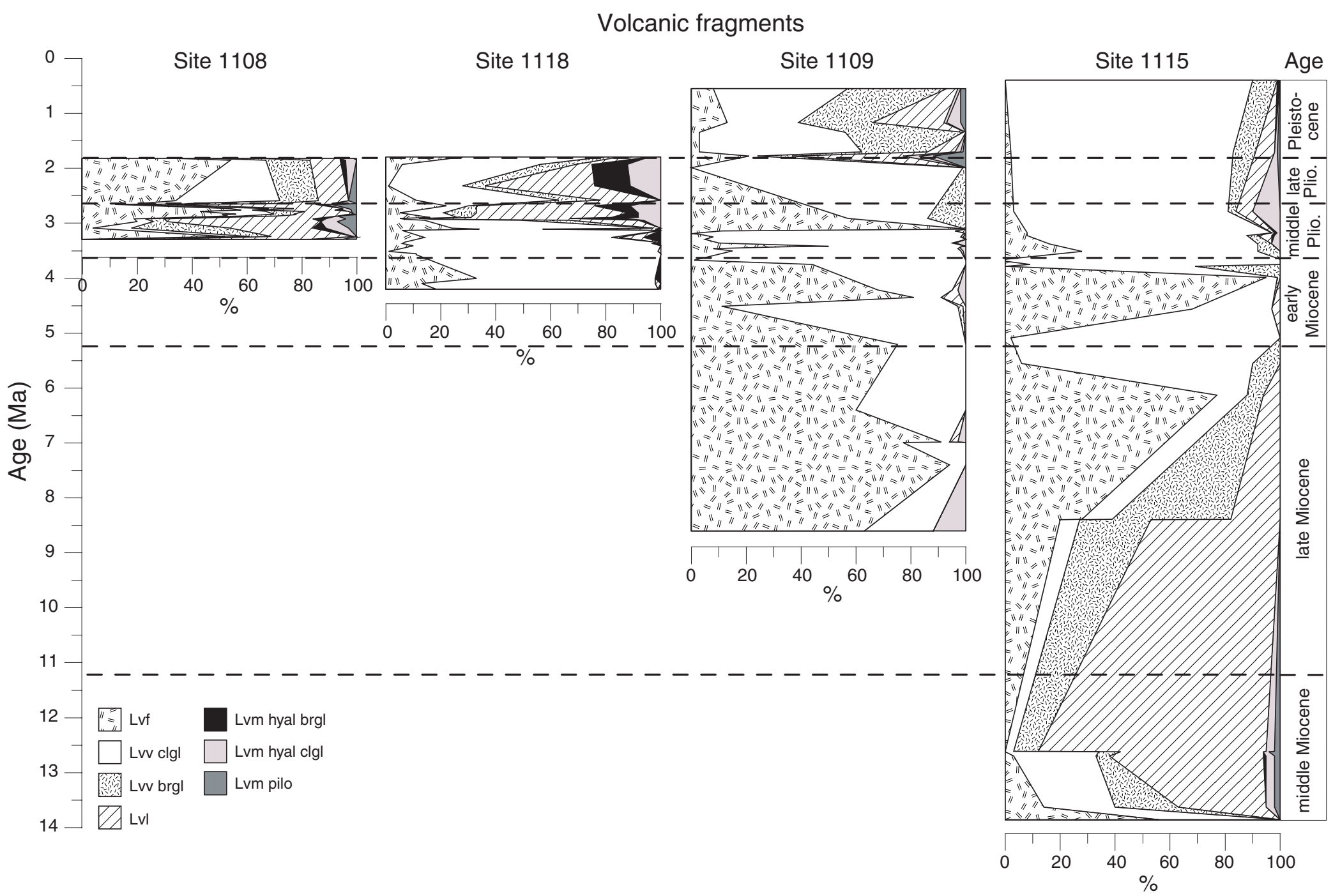


Figure F14. Summary of the sedimentary succession drilled on the Moresby Seamount sites. See Figure F2, p. 26, for locations (from Robertson et al., 2001, modified from Taylor, Huchon, Klaus, et al., 1999).

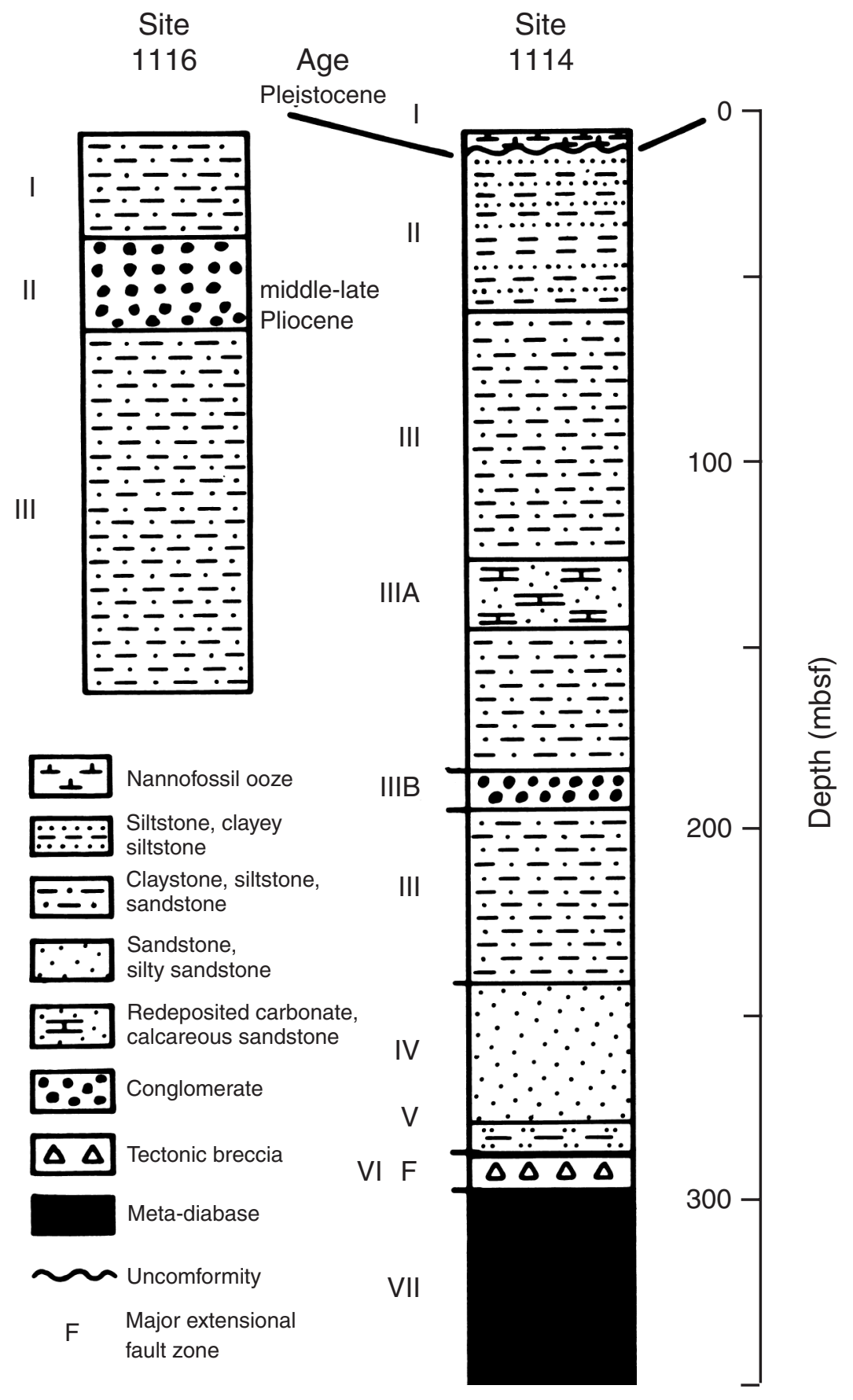


Figure F15. Downhole variation diagrams for Site 1114 (see Table T1, p. 46, for abbreviations and further information). Total detrital cbnte $=$ carbonate skeletal (e.g., foraminifers, shell fragments, red algae, bryozoans, etc.) + carbonate aggre (detital carbonate aggregates), Carb $=$ carbonaceous fragments (plant debris), $\mathrm{Q}=$ total quartzose grains, $\mathrm{F}=$ total feldspar grains, $\mathrm{M}=$ matrix, $\mathrm{C}=$ cement, $\mathrm{Lv}=$ total volcanic grains, $\mathrm{Lm}=$ total metamorphic lithic grains, Biot $=$ biotite, Musc $=$ muscovite, Cpyx $=$ clinopyroxene, Hnbld $=$ hornblende, Lvf $=$ volcanic lithic grains with felsitic texture, $\mathrm{Lvv}$ clgl = colorless vitric volcanic lithic grains, Lvv brgl = brown vitric volcanic lithic grains, Lvl = volcanic lithic grains with lathwork texture, Lvm hyal brgl = volcanic lithic grains with microlites set in a glassy brown groundmass, Lvm hyal clgl = volcanic lithic grains with microlites set in a glassy brown groundmass, Lvm pilo = volcanic lithic grains with interwoven microlites.

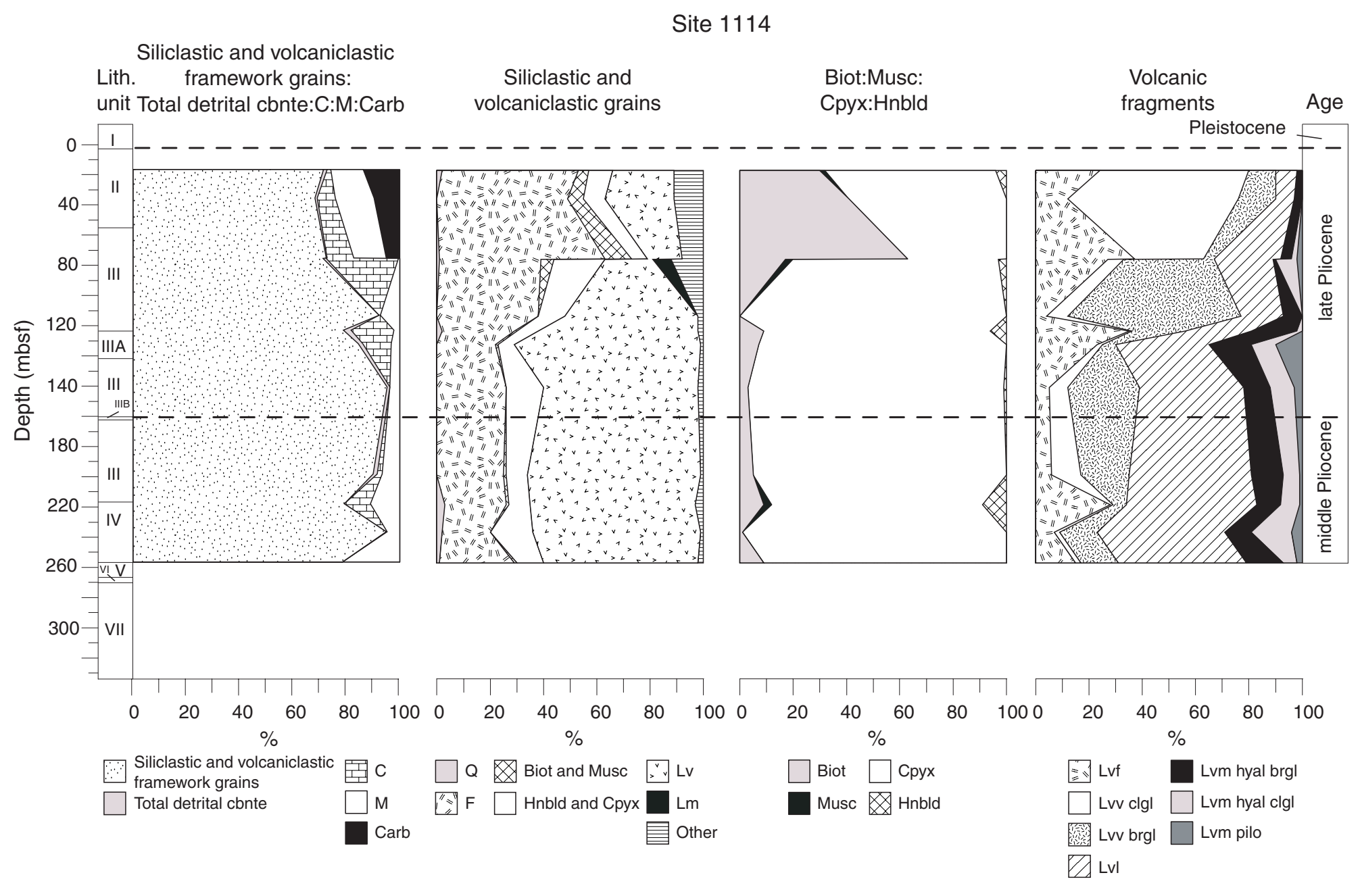


Figure F16. Downhole variation diagrams for Site 1116 (see Table T1, p. 46, for abbreviations and further information). Total detrital cbnte = carbonate skeletal (e.g., foraminifers, shell fragments, red algae, bryozoans, etc.) + carbonate aggre (detital carbonate aggregates), Carb $=$ carbonaceous fragments (plant debris), $\mathrm{Q}=$ total quartzose grains, $\mathrm{F}=$ total feldspar grains, $\mathrm{M}=$ matrix, $\mathrm{C}=$ cement, $\mathrm{Lv}=$ total volcanic grains, $\mathrm{Lm}=$ total metamorphic lithic grains, Biot $=$ biotite, Musc $=$ muscovite, Cpyx $=$ clinopyroxene, Hnbld $=$ hornblende, Lvf $=$ volcanic lithic grains with felsitic texture, $\mathrm{Lvv}$ clgl = colorless vitric volcanic lithic grains, Lvv brgl = brown vitric volcanic lithic grains, Lvl = volcanic lithic grains with lathwork texture, Lvm hyal brgl = volcanic lithic grains with microlites set in a glassy brown groundmass, Lvm hyal clgl = volcanic lithic grains with microlites set in a glassy brown groundmass, Lvm pilo = volcanic lithic grains with interwoven microlites.

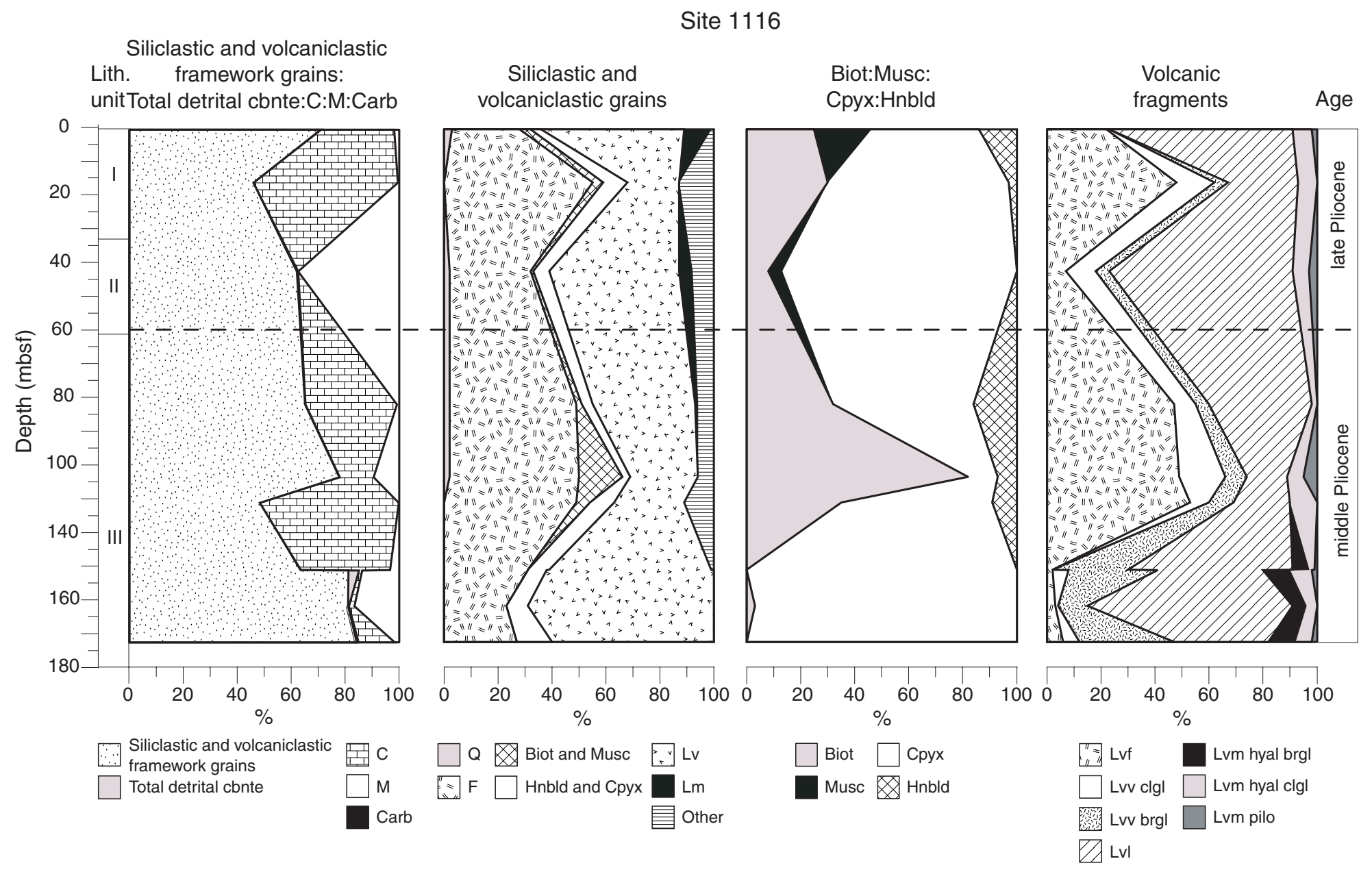


Figure F17. Comparison of downhole variation diagrams for the Moresby Seamount sites (see Table T1, p. 46, for further information). Total detrital cbnte = carbonate skeletal (e.g., foraminifers, shell fragments, red algae, bryozoans, etc.) + carbonate aggre (detital carbonate aggregates), Carb = carbonaceous fragments (plant debris), $\mathrm{Q}=$ total quartzose grains, $\mathrm{F}=$ total feldspar grains, $\mathrm{M}=$ matrix, $\mathrm{C}=$ cement, $\mathrm{Lv}=$ total volcanic grains, $\mathrm{Lm}=$ total metamorphic lithic grains, $\mathrm{Biot}=$ biotite, $\mathrm{Musc}=$ muscovite, $\mathrm{Cpyx}=$ clinopyroxene, Hnbld = hornblende, Lvf = volcanic lithic grains with felsitic texture, Lvv clgl = colorless vitric volcanic lithic grains, Lvv brgl = brown vitric volcanic lithic grains, $\mathrm{Lvl}=$ volcanic lithic grains with lathwork texture, Lvm hyal brgl = volcanic lithic grains with microlites set in a glassy brown groundmass, Lvm hyal clgl = volcanic lithic grains with microlites set in a glassy brown groundmass, Lvm pilo = volcanic lithic grains with interwoven microlites. (Figure shown on next page.) 
Figure F17 (continued). (Caption shown on previous page.)

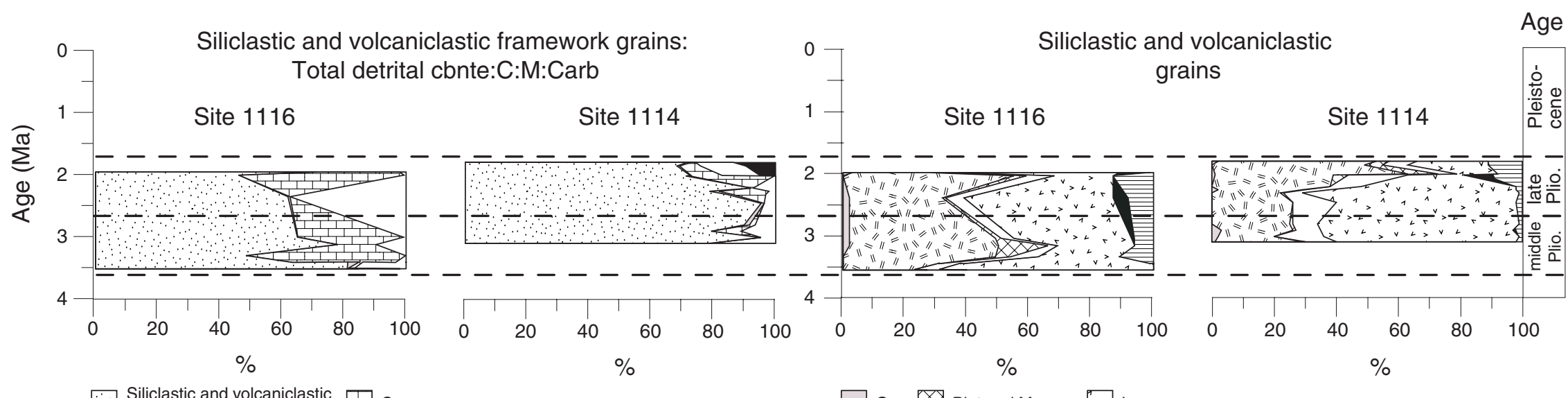

Siliclastic and volcaniclastic
framework grains

$\square$ Total detrital cbnte

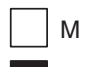

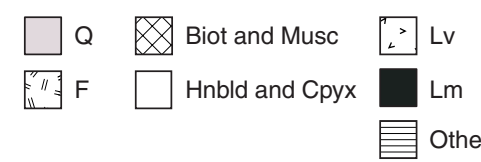

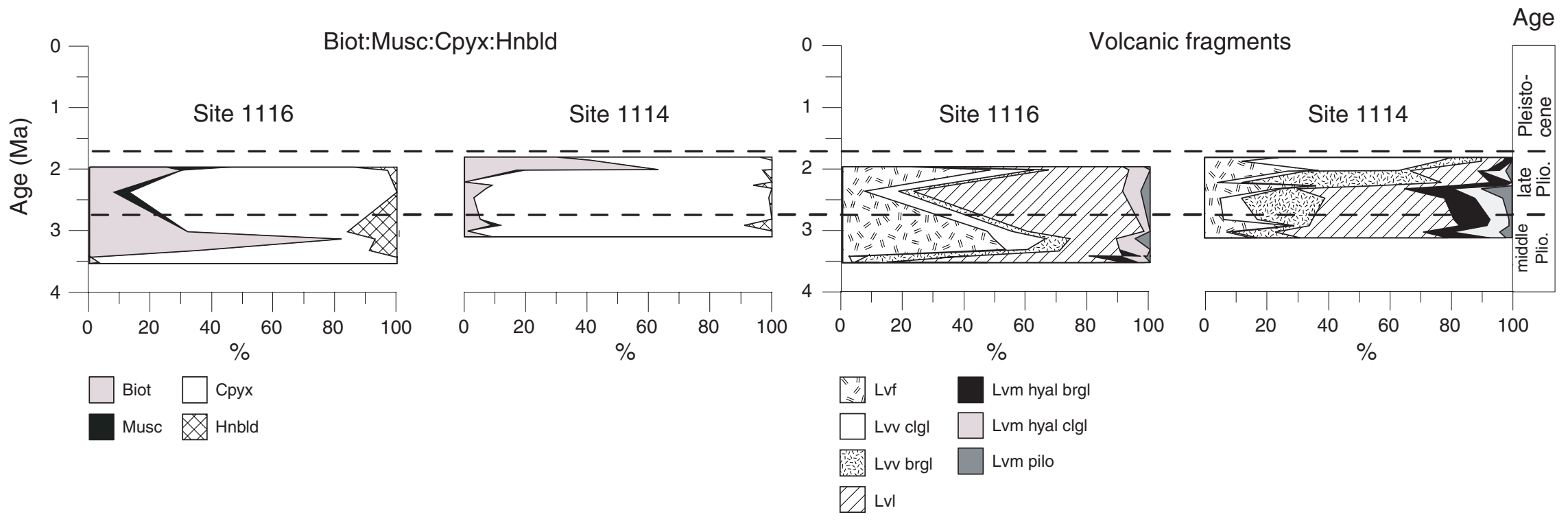




\section{T. SHARP AND A. ROBERTSON \\ VOLCANIC SANDS AND SANDSTONES}

Figure F18. QFL plots of Leg 180 sandstones and sands at different stages in the tectonic evolution of the Woodlark Basin. See "Discussion," p. 17, for further information. Provenance fields are from Dickinson et al. (1983). $\mathrm{CI}=$ craton interior, $\mathrm{TC}=$ transitional continental, $\mathrm{BU}=$ basement uplift, $\mathrm{RO}=$ recycled orogen, $\mathrm{DA}=$ dissected arc, $\mathrm{TA}=$ transitional arc, $\mathrm{UA}=$ undissected arc.

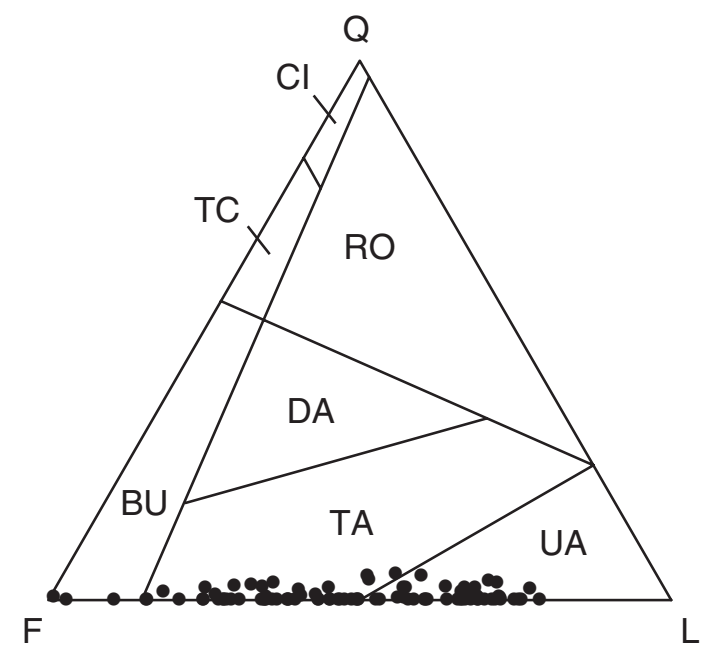

Pliocene sandstones of the Woodlark rift basin

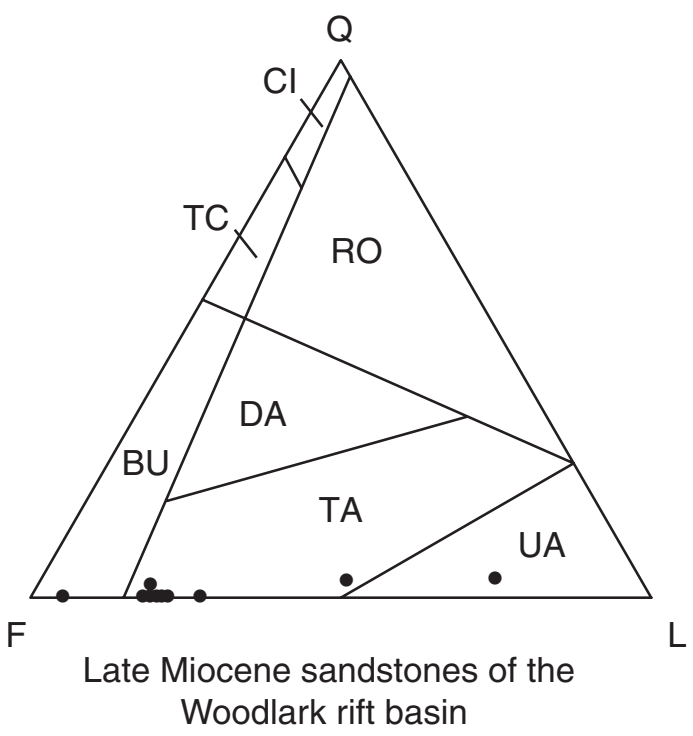

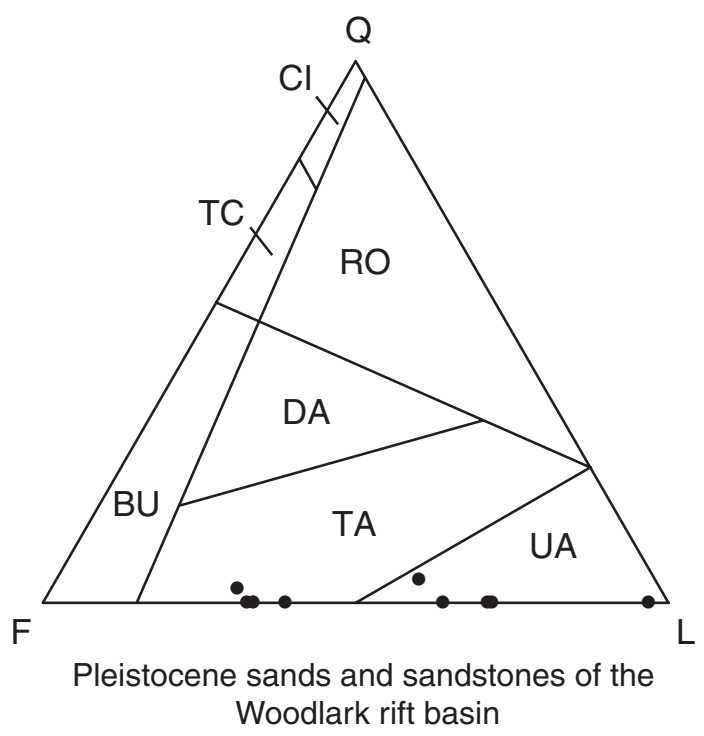

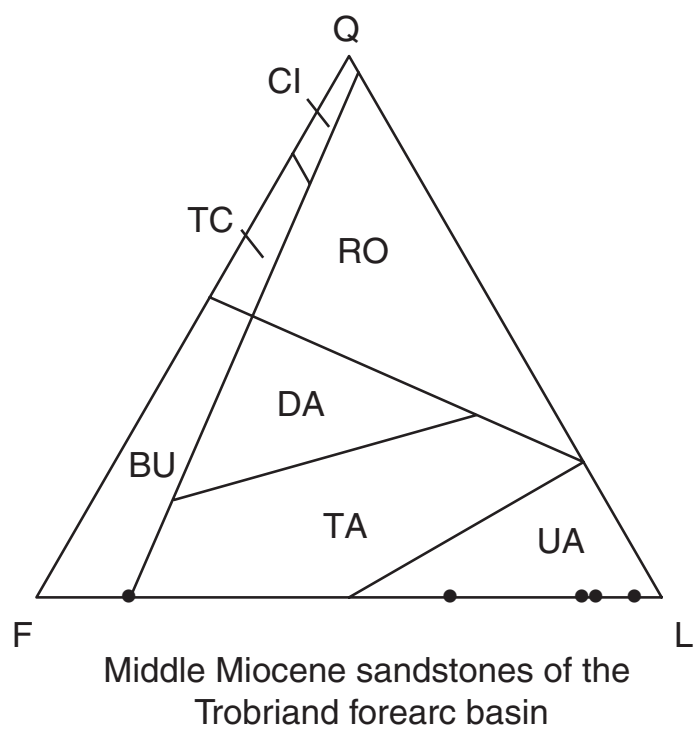


Figure F19. Major changes in provenance and tectonic setting for the Woodlark Basin. See "Discussion," p. 17, for further information (modified from Robertson et al., 2001).

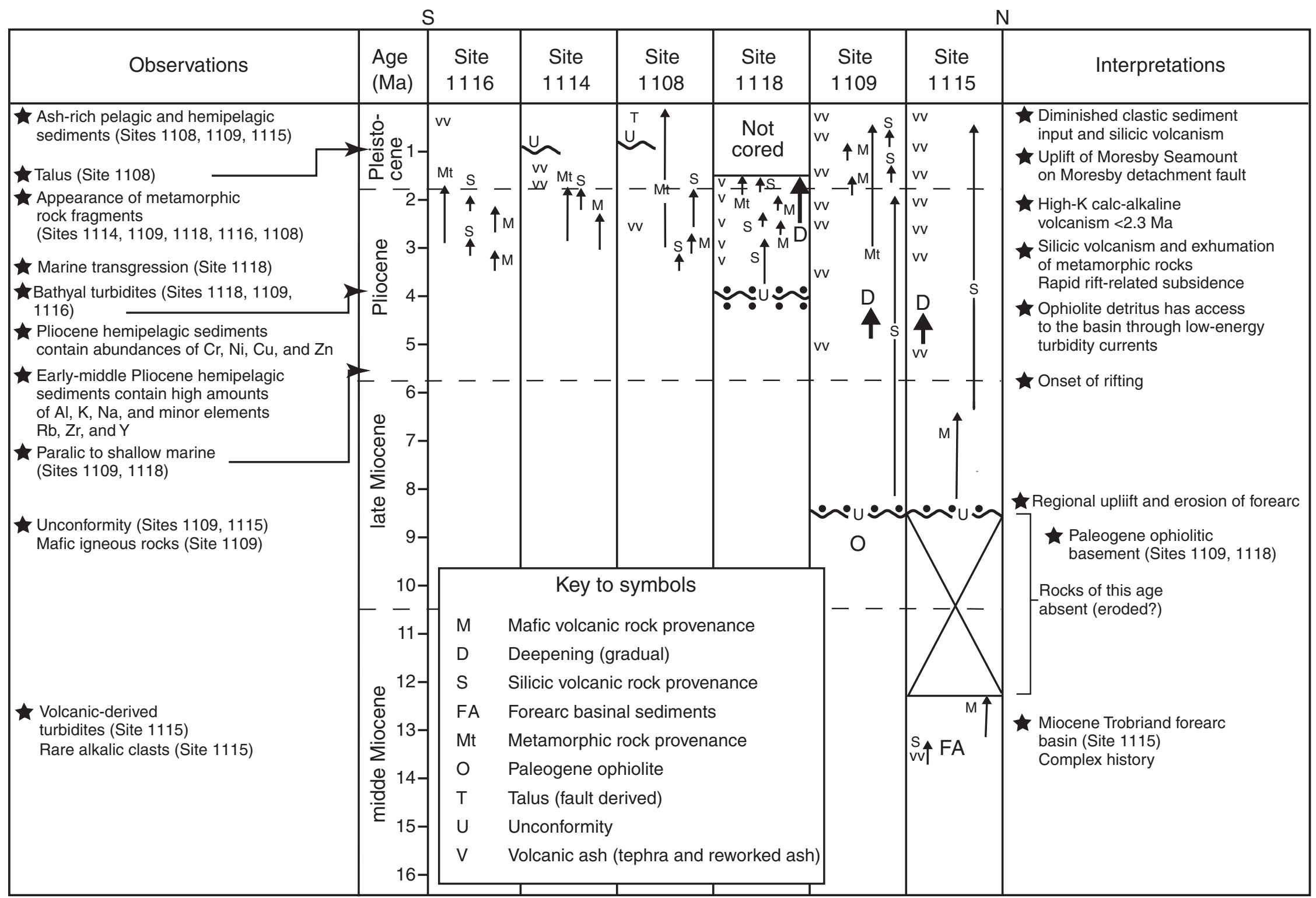


Figure F20. Inferred paleotransport directions at different stages in the tectonic evolution of the Woodlark Basin. See "Discussion," p. 17, for further information (not palinspastically restored; modified from Robertson et al., 2001).

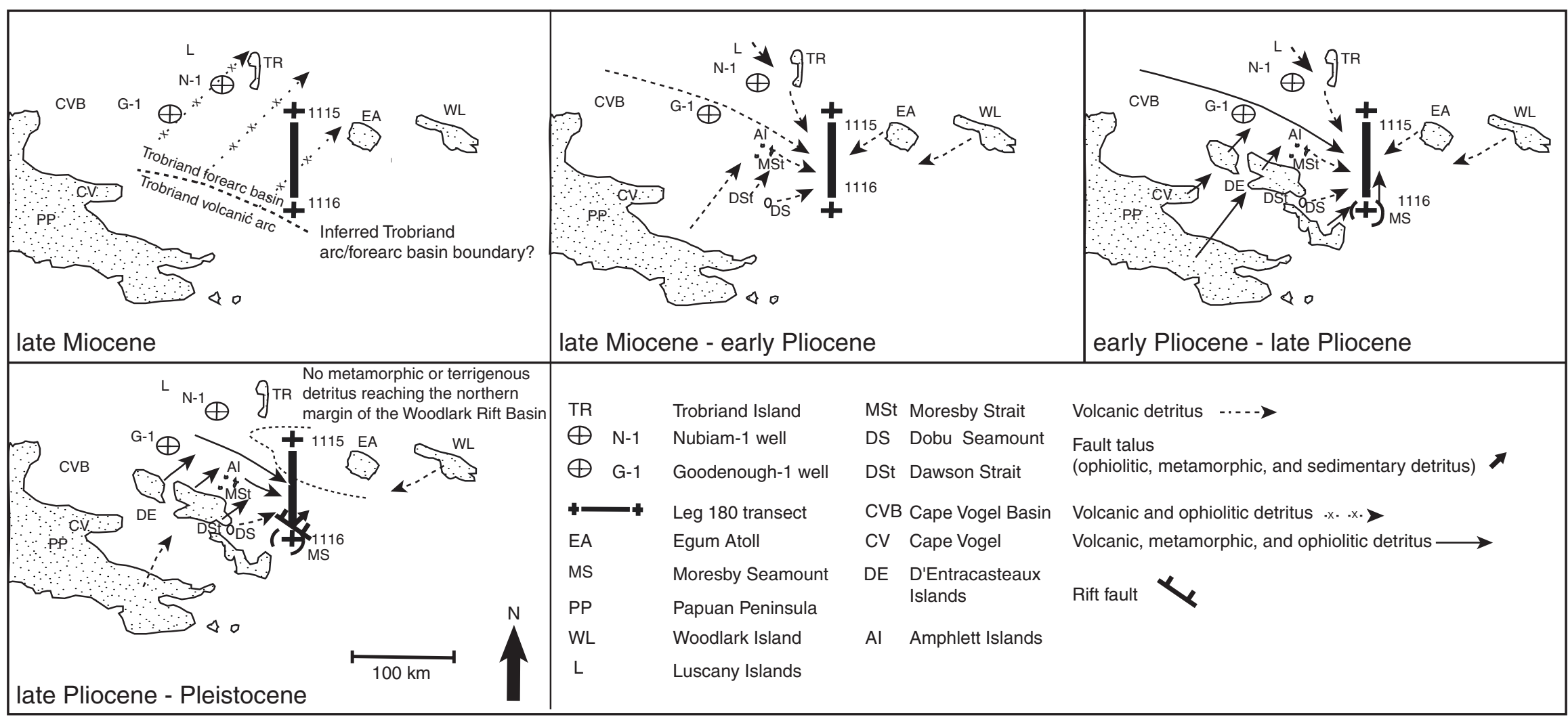


T. SHARP AND A. RobERTSON

VolCANIC SANDS AND SANDSTONES

Table T1. Abbreviations used for all sands and sandstones point counted, Leg 180.

Counted and recalculated parameters

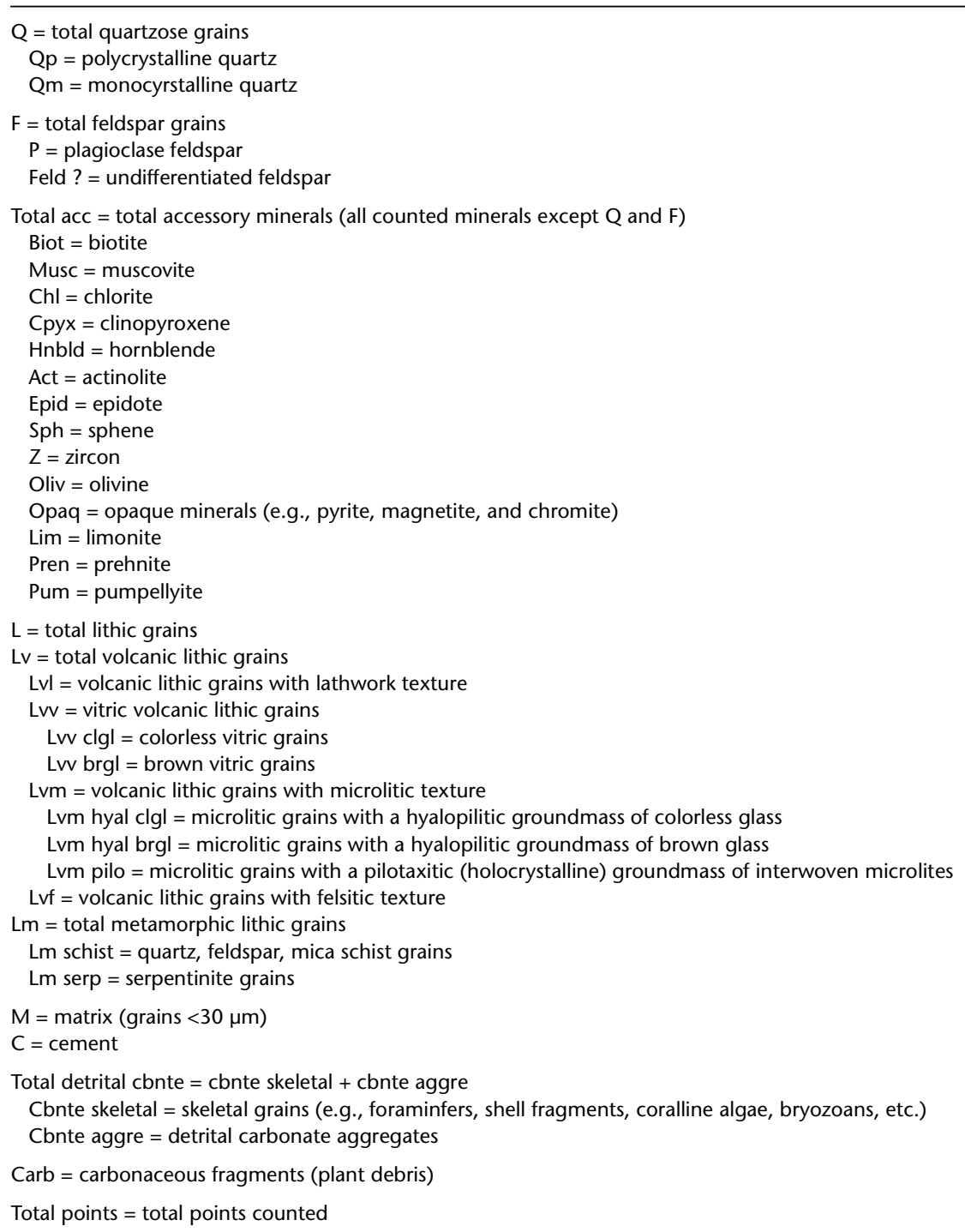


T. SHARP AND A. ROBERTSON

VolCANIC SANDS AND SANDSTONES

Table T2. Raw point-count data for all sands and sandstones point counted, Leg 180. (This table is available in an oversized format.) 
T. SHARP AND A. ROBERTSON

VolCANIC SANDS AND SANDSTONES

Table T3. Recalculated point-count parameter data for all sands and sandstones point counted, Leg 180. (This table is available in an oversized format.) 
Plate P1. Photomicrographs illustrating sands and sandstones of the Woodlark rift. 1. Poorly sorted feldspathic sandstone with common detrital hornblende and biotite grains (Sample 180-1108B-30R-3, 44-46 cm [276.39 mbsf]) (cross-polarized light). 2. Poorly sorted calcite cemented lithic sandstone with subrounded to subangular lathwork, microlitic and felsitic volcanic lithic fragments and detrital feldspar grains (Sample 180-1108A-3R-CC, 0-4 cm [14.50 mbsf]) (cross-polarized light). 3. Well-sorted feldspathic sandstone with common detrital hornblende and biotite grains (Sample 180-1118A-44R-1, 129-130 cm [623.45 mbsf]) (cross-polarized light). 4. A poorly sorted lithic sandstone containing angular to subrounded microlitic, lathwork, and felsitic volcanic lithic fragments, grains of plagioclase, biotite, clinopyroxene, hornblende, and foraminifer tests (Sample 180-1108B-23R-3, 34-36 cm [369.55 mbsf]) (cross-polarized light). 5. A medium-grained feldspathic sand containing fresh angular detrital grains of plagioclase (commonly zoned), biotite, hornblende, and foraminifer tests (Sample 180-1115C-10R-1, 5-7 cm [369.55 mbsf]) (cross-polarized light). 6. Feldspathic sandstone with abundant detrital grains of feldspar, colorless vitric volcanic lithic fragments, biotite, and hornblende in a glass-rich matrix (Sample 180-1109D-3R-2, 148-149 cm [371.68 mbsf]) (plane-polarized light). (Plate shown on next page.) 
T. SHARP AND A. ROBERTSON

VolCANIC SANDS AND SANDSTONES

Plate P1 (continued). (Caption shown on previous page.)
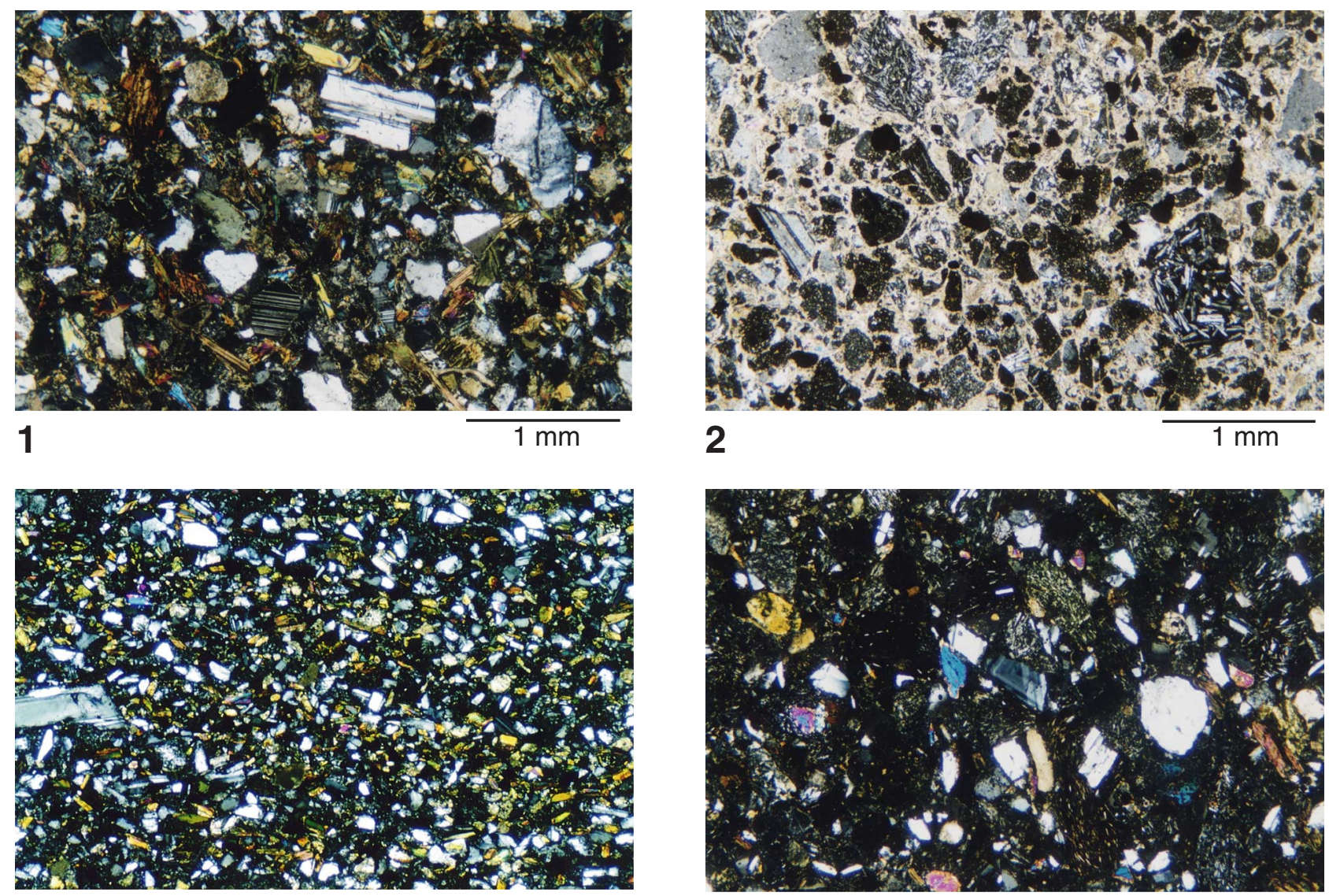

3

$1 \mathrm{~mm}$
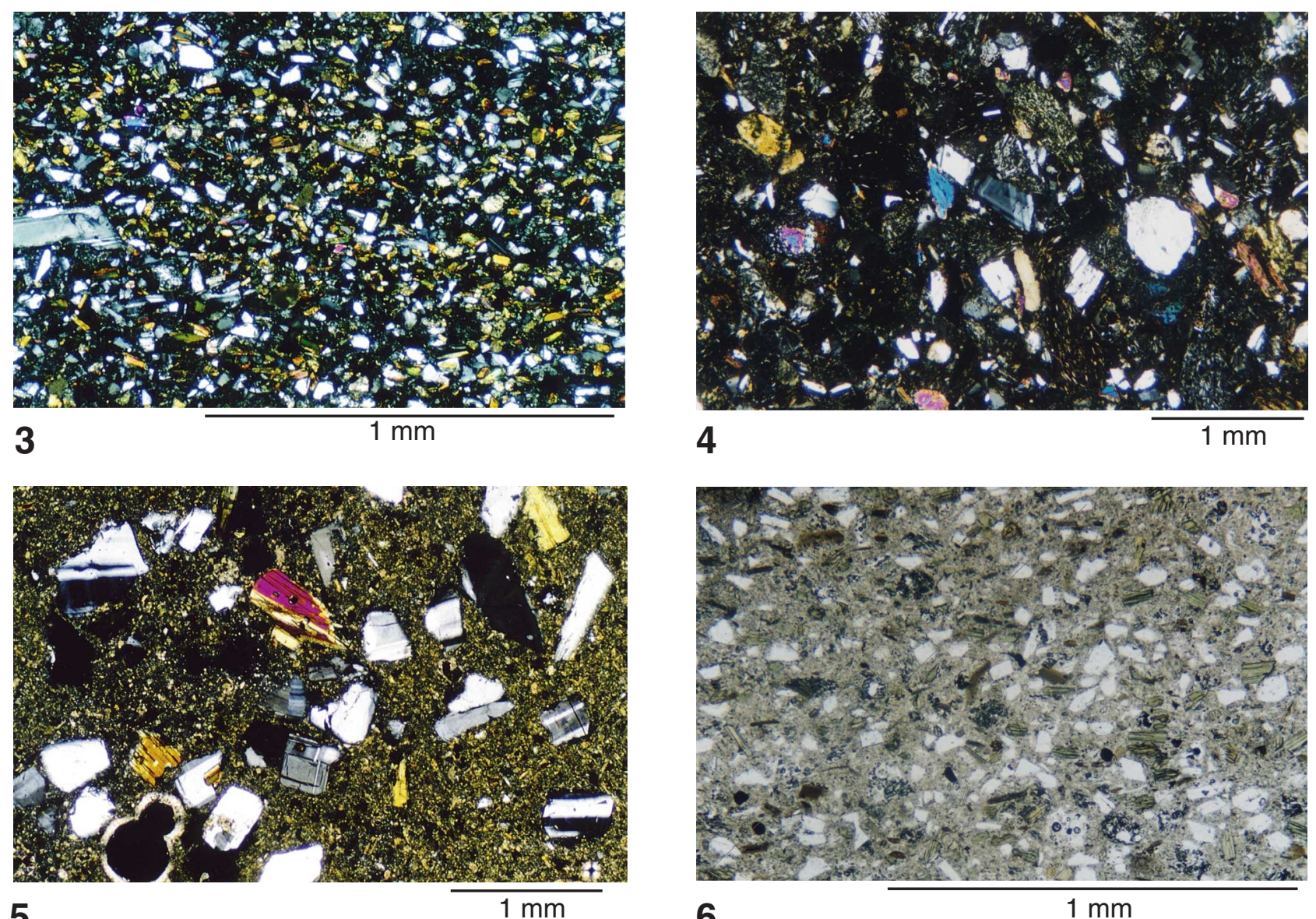

6

$1 \mathrm{~mm}$ 
Plate P2. Photomicrographs illustrating mineral grains present within the sands and sandstones of Woodlark rift. 1. Limonite/goethite concretion surrounded by chloritized volcanic fragments, detrital feldspar, and clinopyroxene grains. (Sample 180-1109D 44R-1, 6-8 cm [753 mbsf]) (plane-polarized light). 2. Detrital biotite grain with authigenic calcite growths along cleavage planes surrounded by detrital grains of feldspar and colorless vitric, brown vitric, and felsitic volcanic lithic fragments. This was interpreted by previous workers as a calc-schist fragment (Sample 180-1116A-11R-1, 16-19 cm [81.96 mbsf]) (plane-polarized light). 3. Detrital grain of glomeroporhyritic clinopyroxene within a calcite-cemented lithic sandstone. Detrital plagioclase and foraminifer are also present (Sample 180-1118A-66R3, 31-34 cm [833.05 mbsf]) (cross-polarized light). 4. A discrete zoned plagioclase grain surrounded by detrital grains of feldspar, biotite, amphibole, and felsitic volcanic lithic fragments within a calcite-cemented lithic sandstone (Sample 1801118A-68R3, 36-39 cm [852.42 mbsf]) (cross-polarized light). 5. Hornblende and feldspar phyric colorless vitric volcanic lithic fragment displaying an internal trachytic texture (Sample 180-1115C-12R-4, 144-148 $\mathrm{cm}$ [394.34 mbsf]) (plane-polarized light). 6. Chalcedony filled vug with calcite rim within a felsitic volcanic lithic fragment (Sample 180-1115C-30R-CC, 16-19 cm [566.89 mbsf]) (cross-polarized light). (Plate shown on next page.) 
T. SHARP AND A. ROBERTSON

VolCANIC SANDS AND SANDSTONES

Plate P2 (continued). (Caption shown on previous page.)

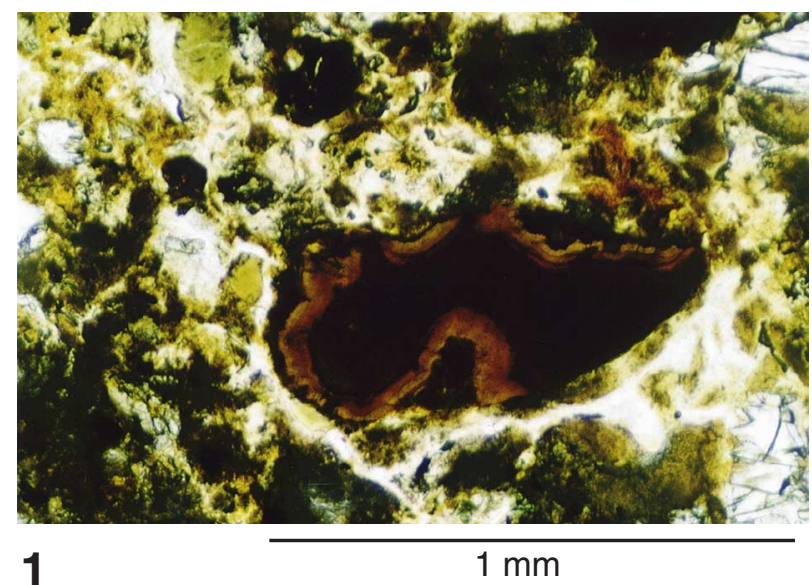

1

$1 \mathrm{~mm}$
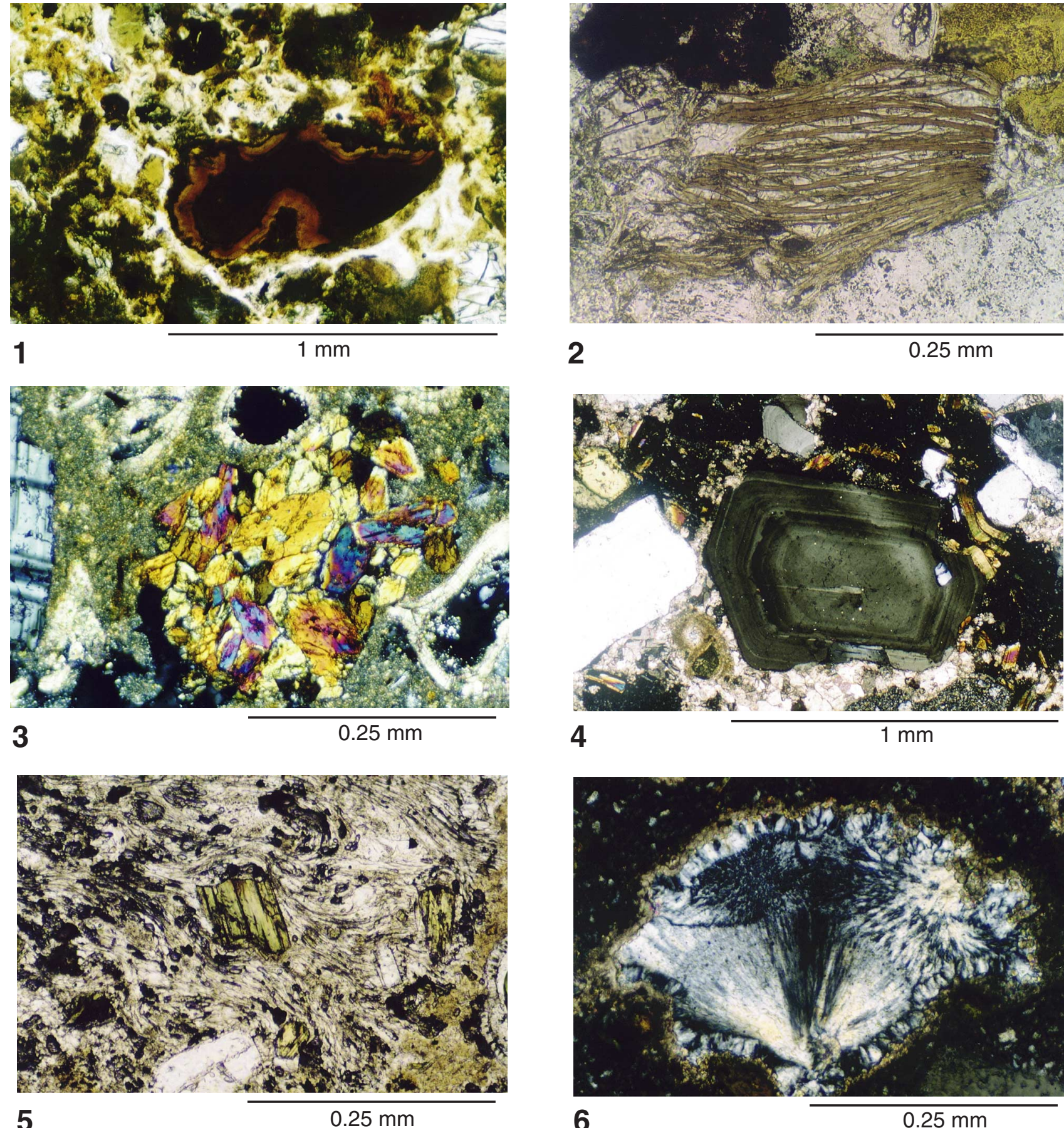

$0.25 \mathrm{~mm}$
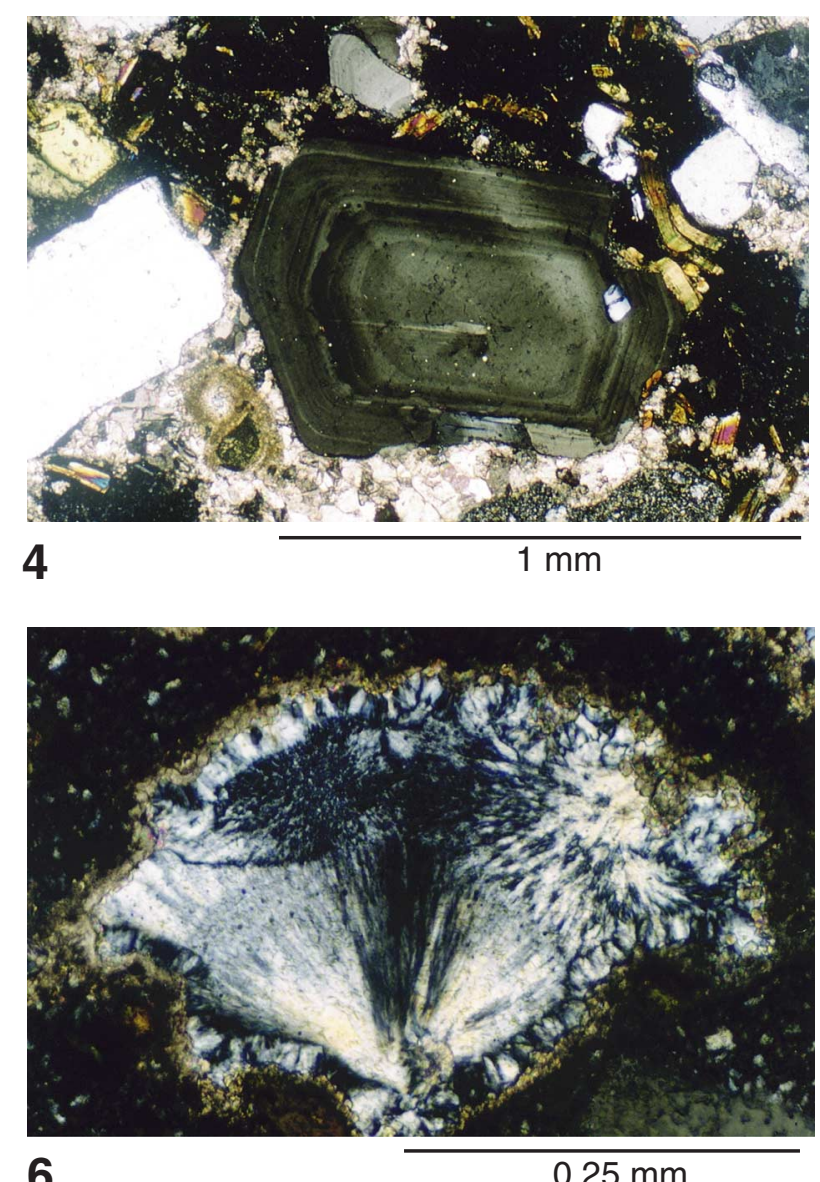
Plate P3. Photomicrographs illustrating metamorphic and serpentinite lithic fragments and mineral grains present within the sands and sandstones of Woodlark rift. 1. Remnant angular colorless olivine grains within a detrital serpentinite grain. Surrounding detrital grains include olivine, feldspar, and colorless and brown vitric volcanic lithic fragments (Sample 180-1108B-24X-CC, 18-20 cm [217.8 mbsf]) (plane-polarized light). 2. A detrital serpentinite grain surrounded by detrital grains of feldspar, biotite, and a fragment of feldspar, quartz, biotite schist. (Sample 180-1108B-36R-3, 52-56 cm [333.94 mbsf]) (cross-polarized light). 3. Metamorphosed volcanic fragments with veins of epidote and chlorite in a feldspathic groundmass. Surrounding detrital grains include feldspar, biotite, prehnite, and magnetite. (Sample 180-1116A6R-1, 9-11 cm [42.49 mbsf]) (cross-polarized light). 4. A feldspar, quartz, biotite schist fragment surrounded by detrital grains of amphibole, clinopyroxene, feldspar, and biotite. Brown vitric and microlitic volcanic lithic fragments are also present (Sample 180-1115C-44R-2, 112-113 cm [698.70 mbsf]) (cross-polarized light). 5. A feldspar, quartz, biotite schist fragment with a remnant feldspar phenocryst. Surrounding detrital grains include amphibole, clinopyroxene, feldspar, and biotite. Microlitic, brown vitric, and colorless vitric volcanic lithic fragments are also present. (Sample 180-1108B-34R-2, 126-128 cm [314.60 mbsf]) (cross-polarized light). 6. Detrital actinolite grain (center) and muscovite lath (center left). Surrounding detrital grains include amphibole, clinopyroxene, feldspar, and biotite. Felsitic, brown vitric, colorless vitric, and microlitic volcanic lithic fragments are also present (Sample 180-1108B-34R-2, 126-128 cm [314.60 mbsf]) (cross-polarized light). (Plate shown on next page.) 
T. SHARP AND A. ROBERTSON

VolCANIC SANDS AND SANDSTONES

Plate P3 (continued). (Caption shown on previous page.)
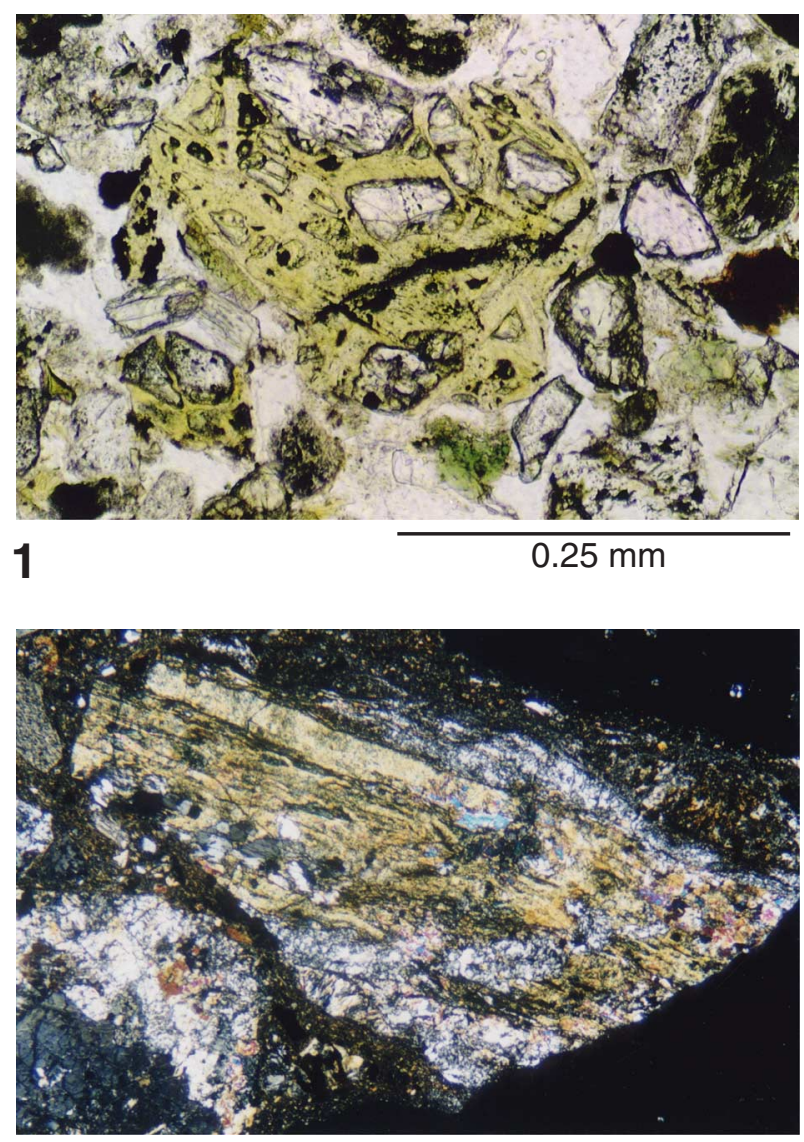

3

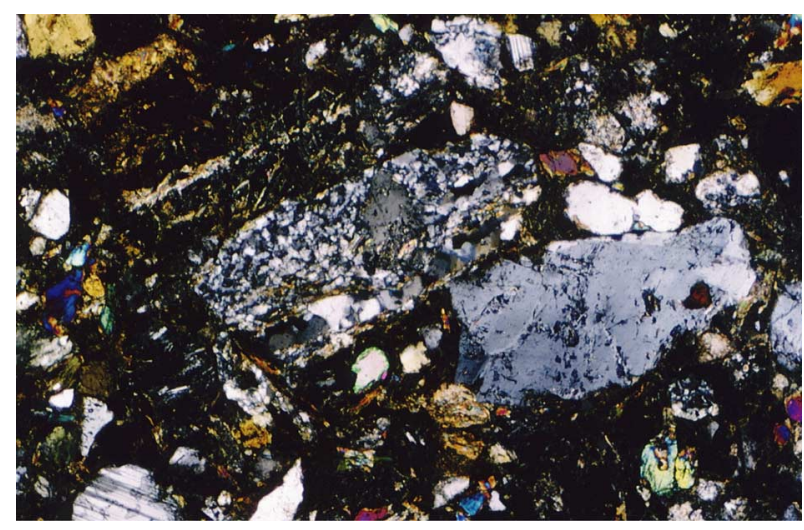

5
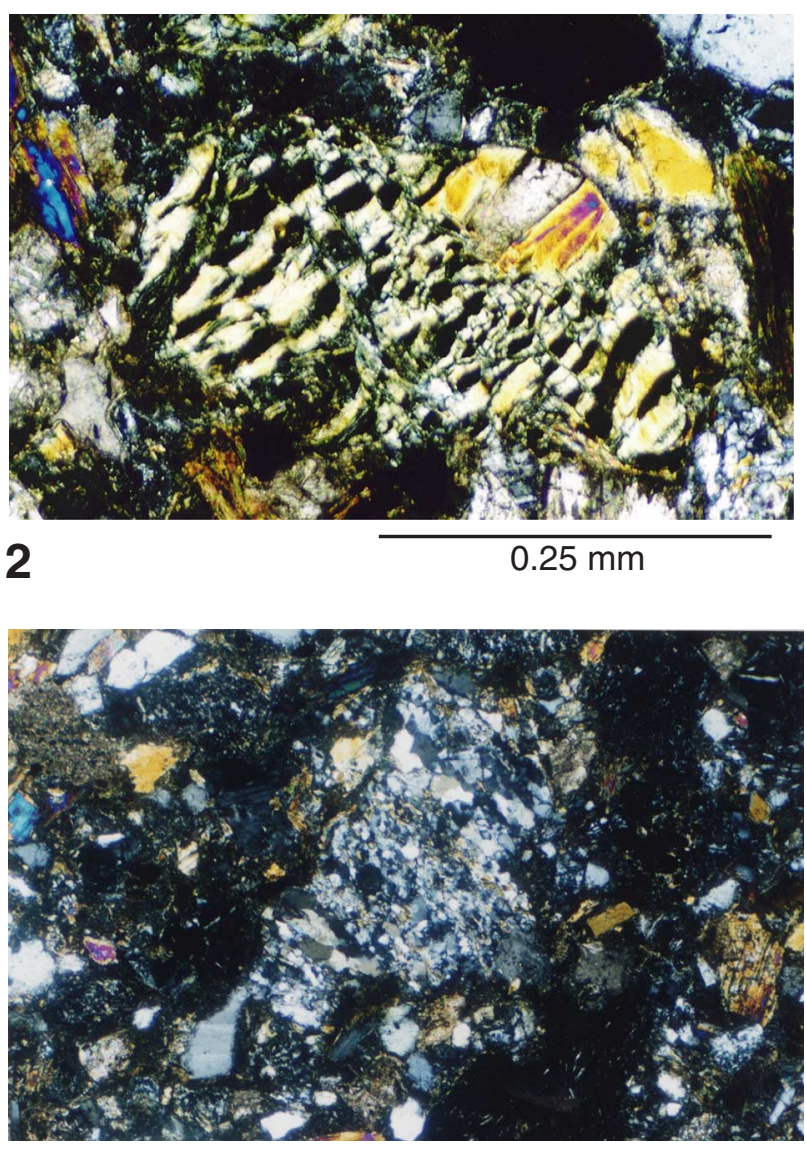

4

$1 \mathrm{~mm}$

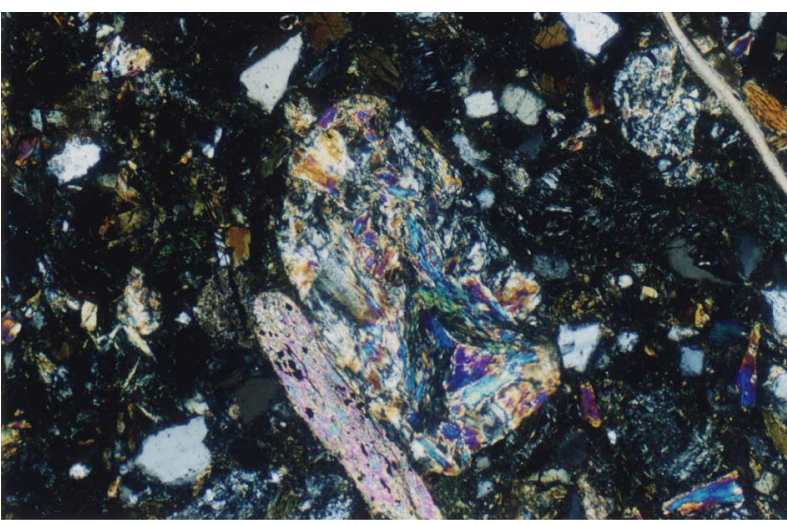

6 
Plate P4. Photomicrographs illustrating volcanic and plutonic lithic fragments within the sands and sandstones of Woodlark rift. 1. A lathwork volcanic lithic fragment with intersertal glass and intergranular clinopyroxene within a calcite-cemented coarse-grained lithic sandstone (Sample 180-1108 3R-CC, 0-4 cm [14.50 mbsf]) (cross-polarized light). 2. Lathwork volcanic lithic fragment with intersertal chlorite and magnetite in a matrix of smectite and chlorite. Surrounding detrital grains include magnetite, felsitic, and partially devitrified colorless vitric volcanic lithic fragments (Sample 180-1118A-71R-1, 13-15 cm [878.53 mbsf]) (cross-polarized light). 3. Lathwork volcanic lithic fragment with intersertal glass surrounded by detrital grains of feldspar, clinopyroxene, and colorless vitric volcanic lithic fragments (Sample 180-1108B-23R-3, 34-36 cm [210.15 mbsf]) (plane-polarized light). 4. Typical lathwork volcanic texture with intergranular clinopyroxene within a dolerite clast from a conglomerate (Sample 180-1109-45R-1, 107-110 cm [764.27 mbsf]) (cross-polarized light). 5. Feldspar and biotite phyric felsitic volcanic lithic fragment surrounded by other felsitic volcanic lithic fragments, brown vitric, and lathwork volcanic lithic fragments, and detrital feldspar set in a calcite-cemented coarse-grained lithic sandstone (Sample 180-1116A-1R-1, 58-60 cm [0.58 mbsf]) (cross-polarized light). 6. Detrital grain composed of intergrown feldspar, biotite, and hornblende (granitic fragment) surrounded by lathwork and microlitic volcanic lithic and feldspar detrital grains in calcite-cemented coarse-grained lithic sandstone (Sample 180-1108B-3R-CC, 0-4 cm [14.50 mbsf]) (cross-polarized light). (Plate shown on next page.) 
T. SHARP AND A. ROBERTSON

VolCANIC SANDS AND SANDSTONES

Plate P4 (continued). (Caption shown on previous page.)
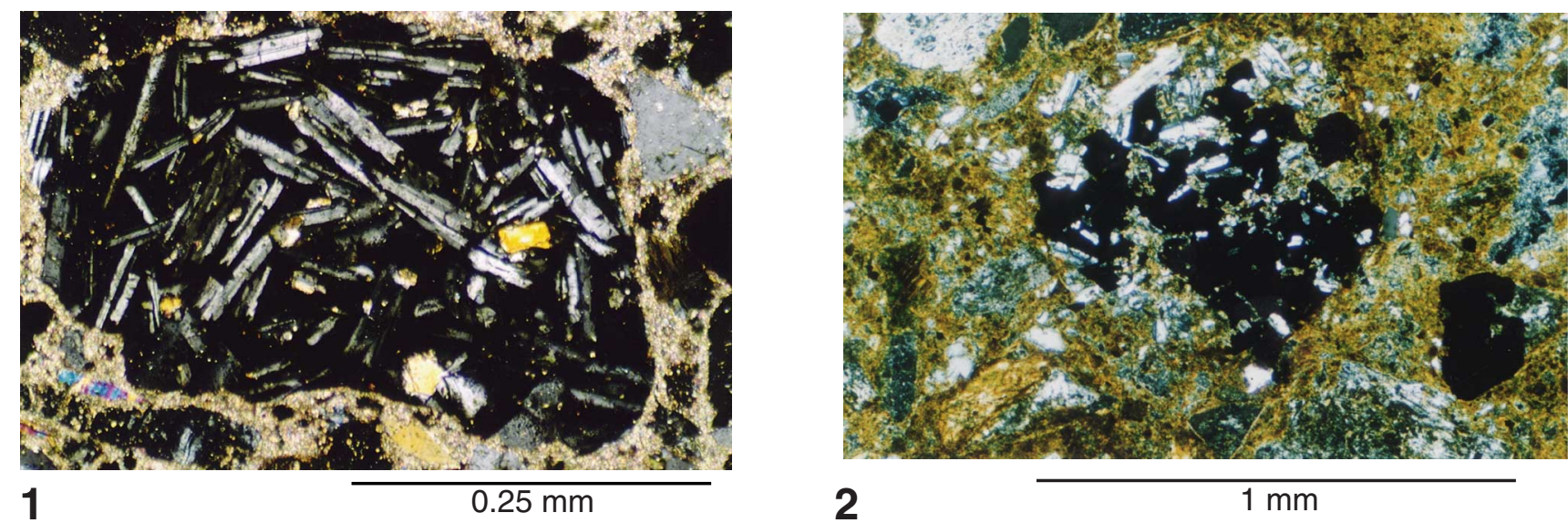

2

$1 \mathrm{~mm}$
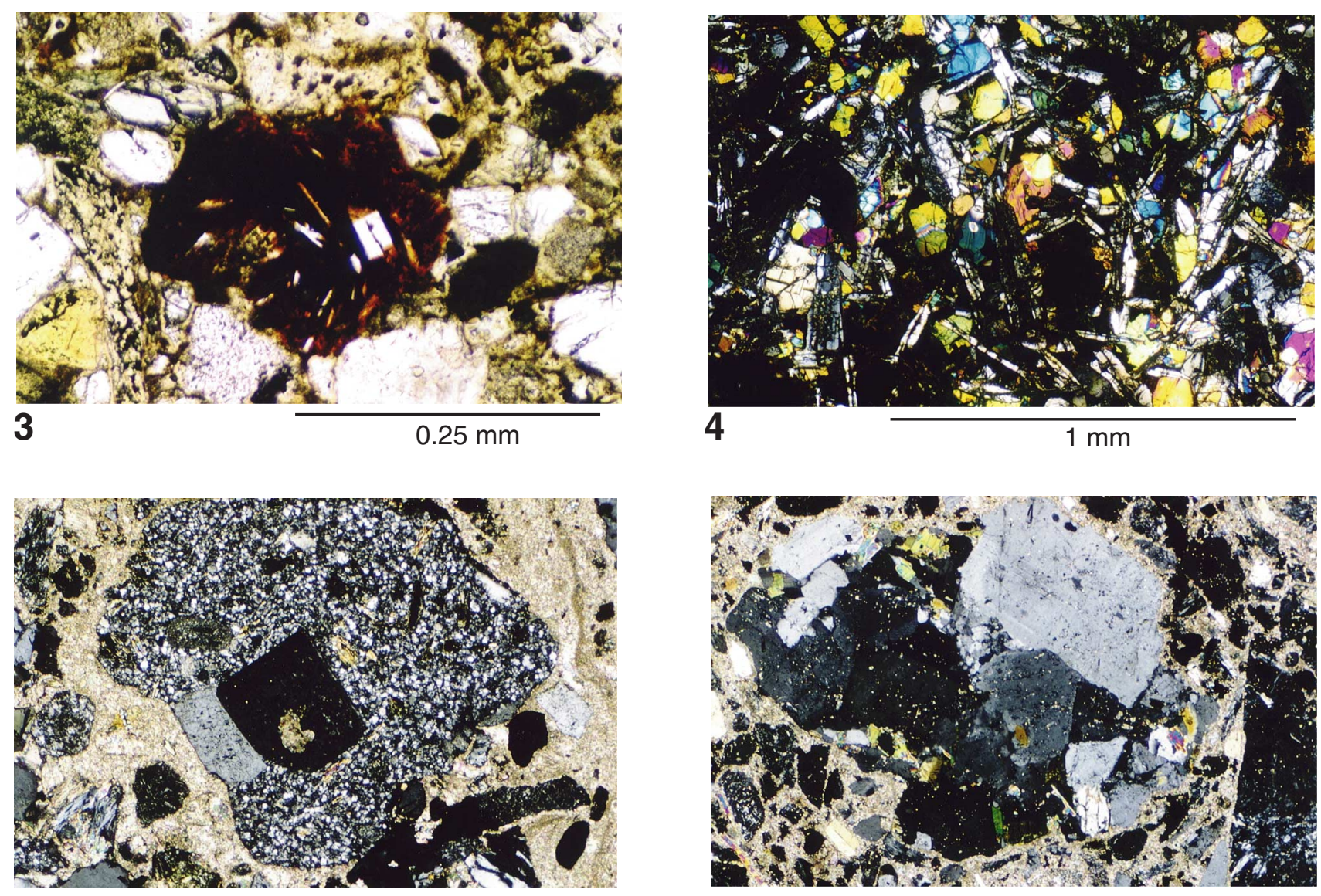

5

$1 \mathrm{~mm}$

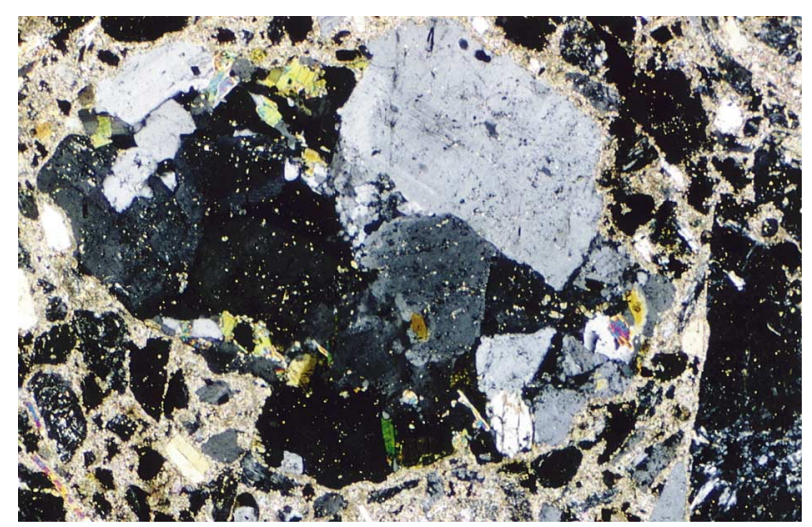

6

$1 \mathrm{~mm}$ 
Plate P5. Photomicrographs illustrating volcanic lithic fragments present within the sands and sandstones of Woodlark rift. 1. Colorless vitric volcanic lithic fragments (in places chloritized) and a slightly deformed detrital biotite grain. Authigenic pyrite grains are also present (Sample 180-1118A-68R-3, 102-105 cm [853.08 mbsf]) (plane-polarized light). 2. Brown vitric volcanic lithic fragment with vesicles and rare plagioclase laths, surrounded by colorless vitric, brown vitric and lathwork volcanic lithic fragments and detrital feldspar grains (Sample 180-1114A-14R-1, 106-108 cm [123.46 mbsf]) (plane-polarized light). 3. Plagioclase, hornblende, and biotite phyric brown vitric volcanic lithic fragment surrounded by lathwork, felsitic, and vitric volcanic lithic fragments, and detrital feldspar grains set in a calcite-cemented coarsegrained lithic sandstone (Sample 180-1108-3R-CC, 0-4 cm [14.5 mbsf]) (plane-polarized light). 4. Clinopyroxene and feldspar phyric pilotaxitic microlitic volcanic lithic fragment displaying a trachytic texture. Surrounding detrital grains include brown vitric, colorless vitric, and lathwork volcanic lithic fragments, feldspar, and clinopyroxene (Sample 180-1108A-28R-CC, 3-7 cm [256.93 mbsf]) (plane-polarized light). 5. Pilotaxitic microlitic volcanic lithic fragment with trachytic texture. Surrounding detrital grains include feldspar, clinopyroxene, amphibole, biotite, brown vitric volcanic fragments, and foraminifers (Sample 180-1108A-34R-2, 126-128 cm [314.60 mbsf]) (cross-polarized light). 6. Clinopyroxene and feldspar phyric brown hyalopilitic volcanic lithic fragment surrounded by feldspar, clinopyroxene, brown vitric, lathwork, and microlitic volcanic lithic fragments (Sample 180-1112A-9R-CC, 25-27 [78.15 mbsf]) (plane-polarized light). (Plate shown on next page.) 
T. SHARP AND A. ROBERTSON

VolCANIC SANDS AND SANDSTONES

Plate P5 (continued). (Caption shown on previous page.)
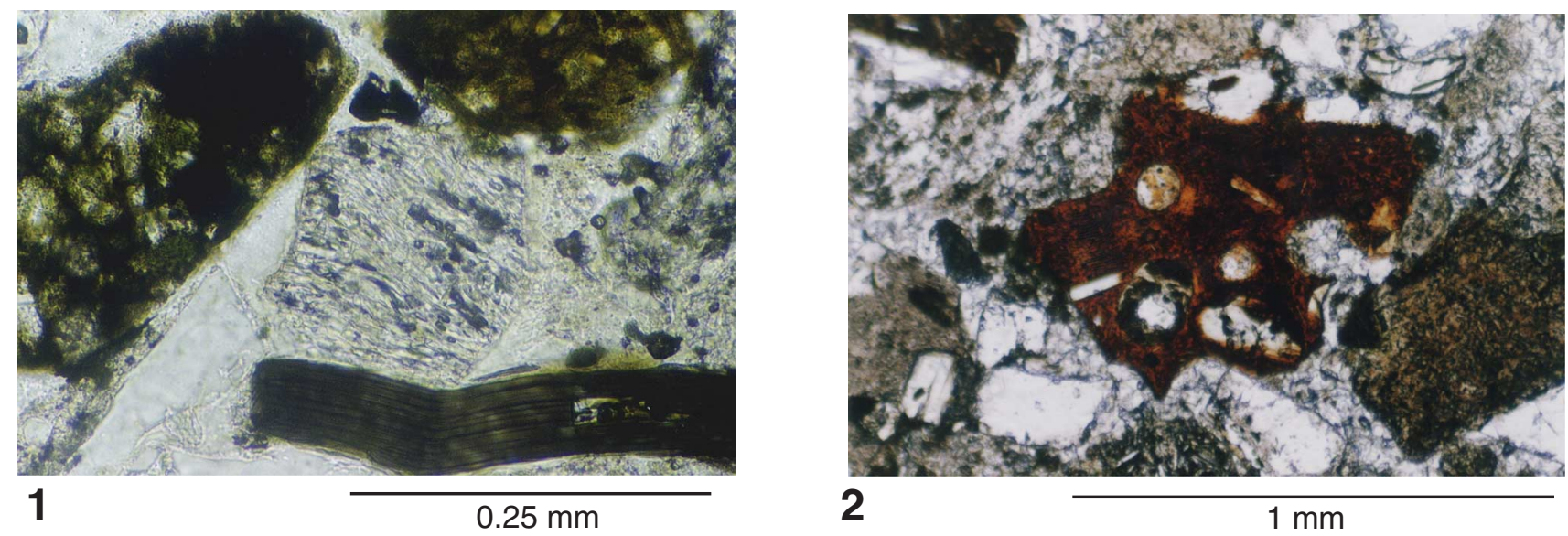

2

$1 \mathrm{~mm}$

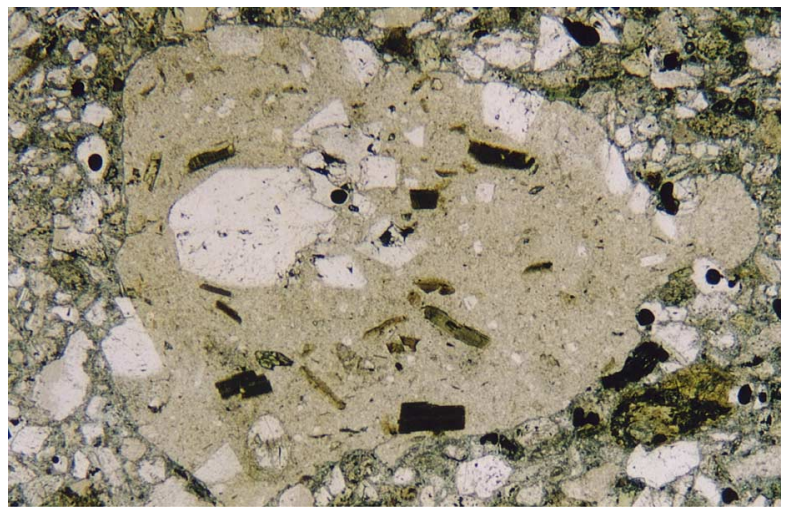

3

$1 \mathrm{~mm}$
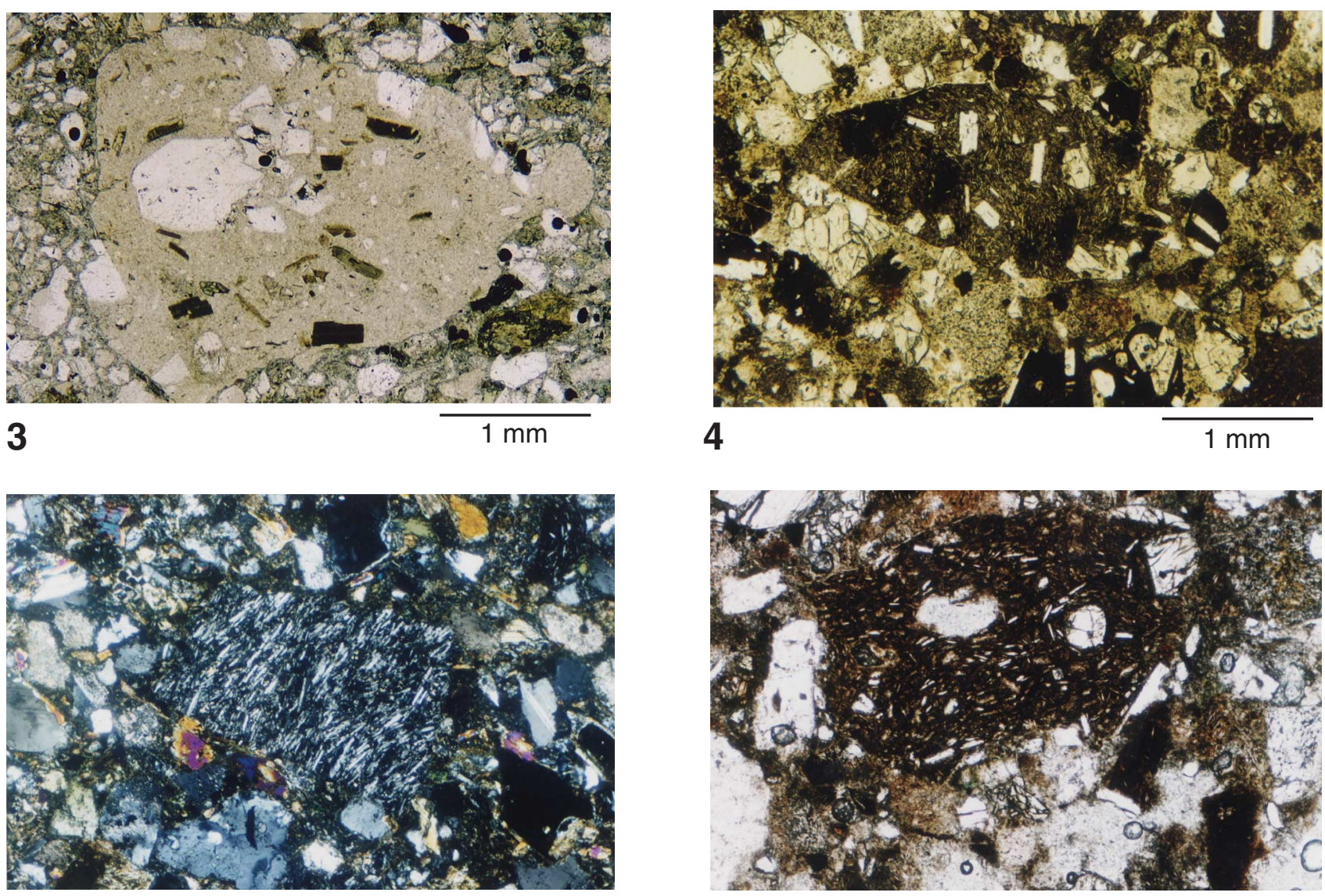

5

$1 \mathrm{~mm}$

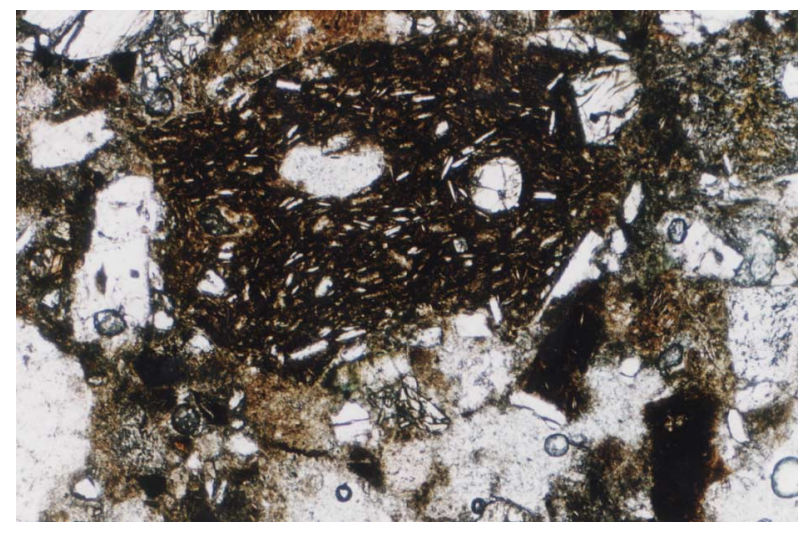

6

$1 \mathrm{~mm}$ 